Nevada

Environmental

Restoration

Project

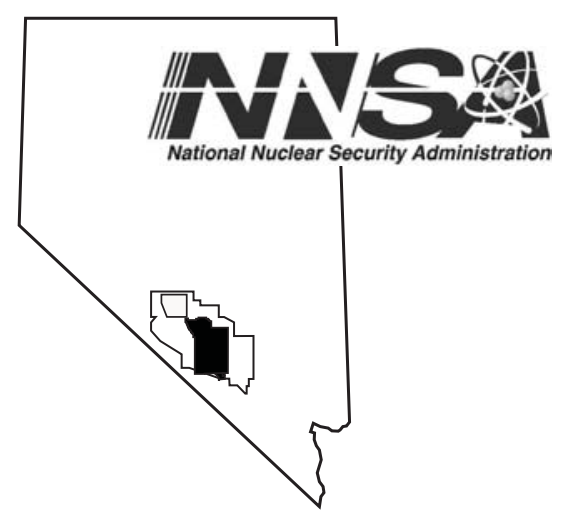

\title{
Completion Report for Well ER-EC-5
}

October 2004

\section{Environmental Restoration}

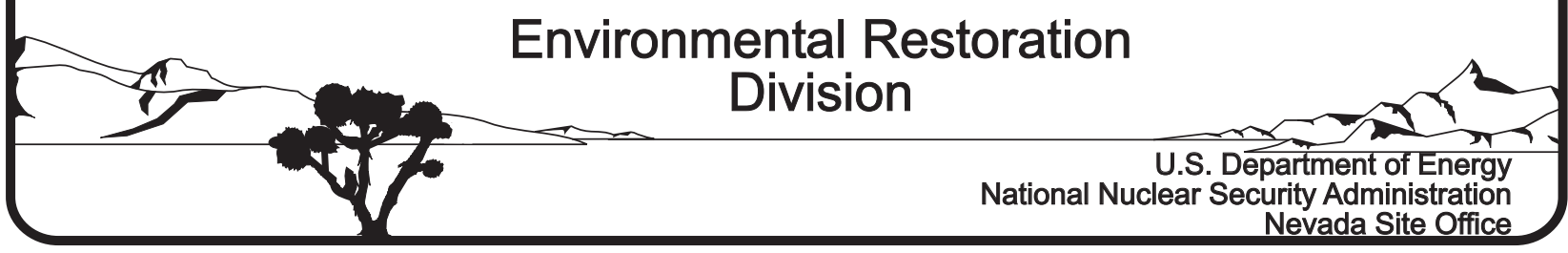




\section{DISCLAIMER STATEMENT}

Reference herein to any specific commercial product, process, or service by trade name, trademark, manufacturer, or otherwise, does not necessarily constitute or imply its endorsement, recommendation, or favoring by the U.S. Government or any agency thereof or its contractors or subcontractors.

\section{AVAILABILITY STATEMENT}

Available for sale to the public from:

U.S. Department of Commerce

National Technical Information Service

5285 Port Royal Road

Springfield, VA, 22161-0002

Telephone: 800.553 .6847 or 703.605 .6000

Fax: 703.605.6900

E-mail: orders@ntis.gov

Online ordering: http://www.ntis.gov/ordering.htm

Available electronically at http://www.osti.gov/bridge.

Available for a processing fee to U.S. Department of Energy and its contractors, in paper, from:

U.S. Department of Energy

Office of Scientific and Technical Information

P.O. Box 62

Oak Ridge, TN, 37831-0062

Telephone: 865.576 .8401

Fax: 865.576.5728

E-mail: reports@adonis.osti.gov 


\title{
Completion Report for Well ER-EC-5
}

\author{
Prepared for: \\ U. S. Department of Energy \\ National Nuclear Security Administration \\ Nevada Site Office \\ Las Vegas, Nevada
}

Prepared by:

Bechtel Nevada

Geotechnical Sciences

Las Vegas, Nevada

October 2004 
This page intentionally left blank. 


\section{COMPLETION REPORT FOR WELL ER-EC-5}

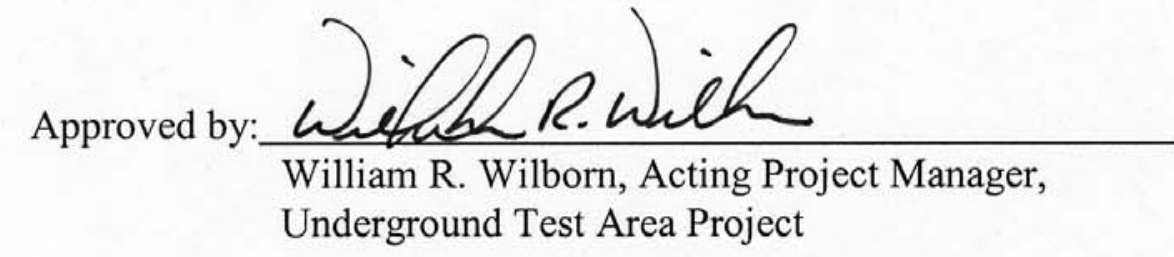

Date: 11/24/04

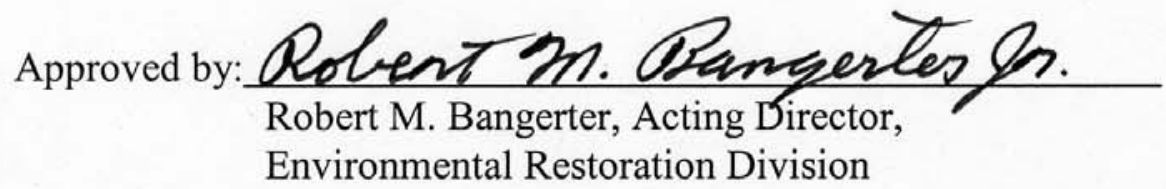

Date: $11 / 24 / 04$ 
This page intentionally left blank. 


\title{
Completion Report for Well ER-EC-5 \\ DOE/NV/11718-424
}

\begin{abstract}
Well ER-EC-5 was drilled for the U.S. Department of Energy, National Nuclear Security Administration Nevada Site Office in support of the Nevada Environmental Restoration Project at the Nevada Test Site, Nye County, Nevada. This well was drilled in the summer of 1999 as part of the U.S. Department of Energy's hydrogeologic investigation program in the Western Pahute Mesa - Oasis Valley region just west of the Nevada Test Site. A 44.5-centimeter surface hole was drilled and cased off to a depth of 342.6 meters below ground surface. The borehole diameter was then decreased to 31.1 centimeters for drilling to a total depth of 762.0 meters.
\end{abstract}

One completion string with three isolated slotted intervals was installed in the well. A preliminary composite, static water level was measured at the depth of 309.9 meters, 40 days after installation of the completion string.

Detailed lithologic descriptions with stratigraphic assignments are included in the report. These are based on composite drill cuttings collected every 3 meters, and 18 sidewall samples taken at various depths below 349.6 meters, supplemented by geophysical log data and results from detailed chemical and mineralogical analyses of rock samples. The well penetrated Tertiary-age tuffs of the Thirsty Canyon Group, caldera moat-filling sedimentary deposits, lava of the Beatty Wash Formation, and landslide breccia and tuffs of the Timber Mountain Group. The well reached total depth in welded ashflow tuff of the Ammonia Tanks Tuff after penetrating 440.1 meters of this unit, which is also the main water-producing unit in the well. The geologic interpretation of data from this well constrains the western margin of the Ammonia Tanks caldera to the west of the well location. 
This page intentionally left blank. 


\section{Table of Contents}

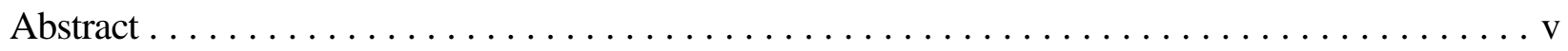

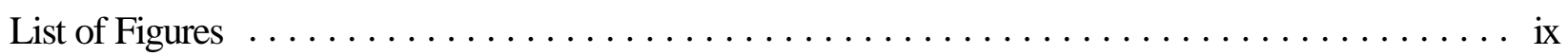

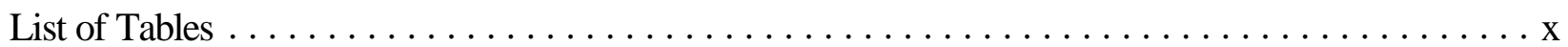

List of Acronyms and Abbreviations $\ldots \ldots \ldots \ldots \ldots \ldots \ldots \ldots \ldots \ldots \ldots \ldots \ldots \ldots \ldots \ldots$

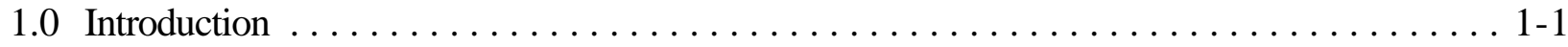

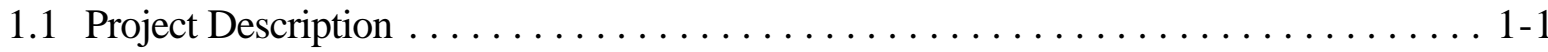

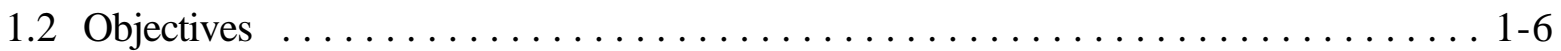

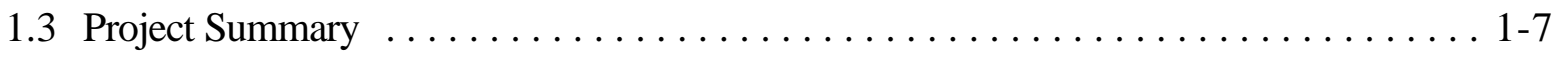

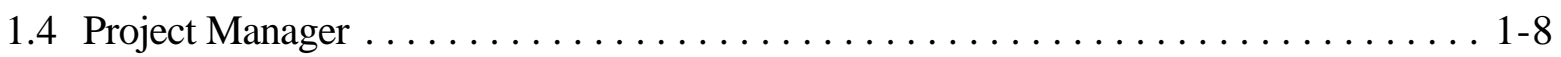

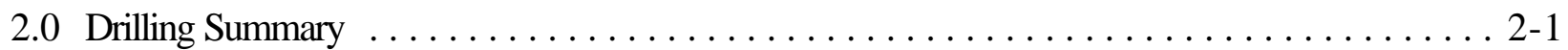

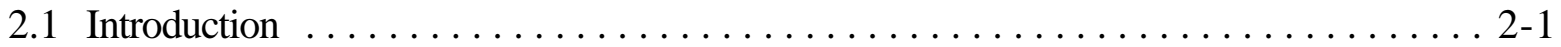

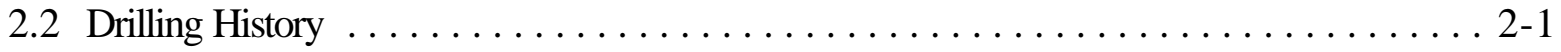

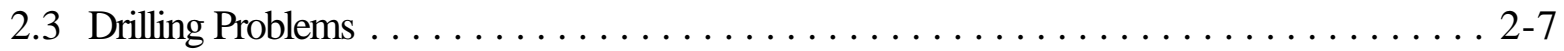

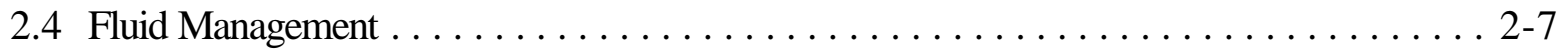

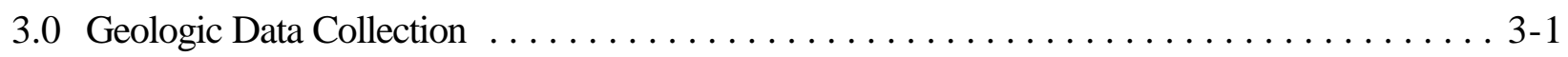

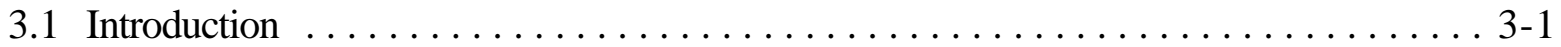

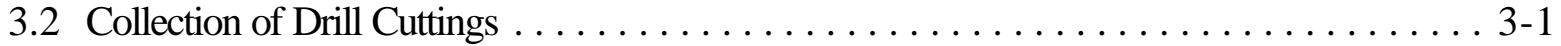

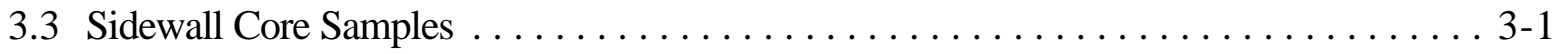

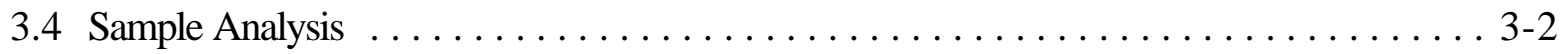

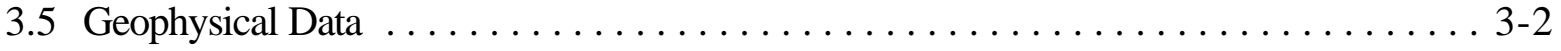

4.0 Geology and Hydrogeology $\ldots \ldots \ldots \ldots \ldots \ldots \ldots \ldots \ldots \ldots \ldots \ldots \ldots \ldots \ldots \ldots$

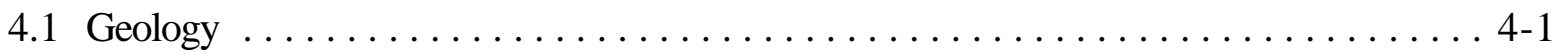

4.2 Predicted Versus Actual Geology $\ldots \ldots \ldots \ldots \ldots \ldots \ldots \ldots \ldots \ldots \ldots \ldots \ldots \ldots$

4.3 Hydrogeology . . . . . . . . . . . . . . . . . . . . . . . 4-14

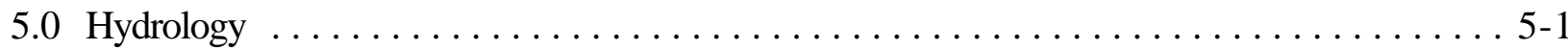

5.1 Preliminary Water-Level Information $\ldots \ldots \ldots \ldots \ldots \ldots \ldots \ldots \ldots \ldots \ldots \ldots \ldots \ldots$

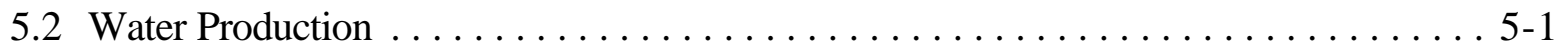

5.3 Preliminary Thermal Flow Meter Data $\ldots \ldots \ldots \ldots \ldots \ldots \ldots \ldots \ldots \ldots \ldots \ldots \ldots \ldots \ldots \ldots .2$

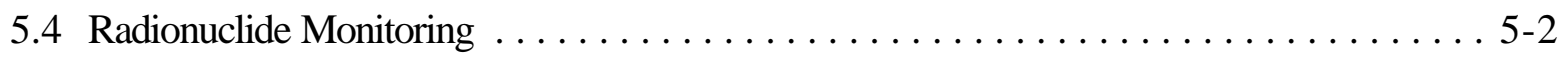

5.5 Preliminary Groundwater Characterization Sample $\ldots \ldots \ldots \ldots \ldots \ldots \ldots \ldots \ldots$. . . . . 
6.0 Precompletion and Open-Hole Development $\ldots \ldots \ldots \ldots \ldots \ldots \ldots \ldots \ldots \ldots \ldots .6,1$

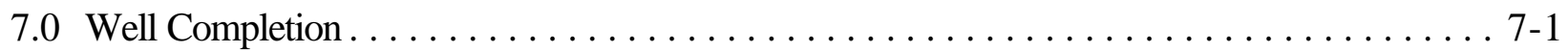

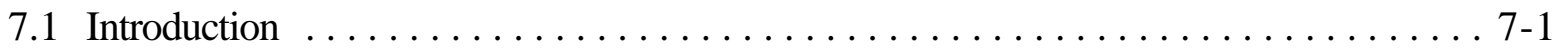

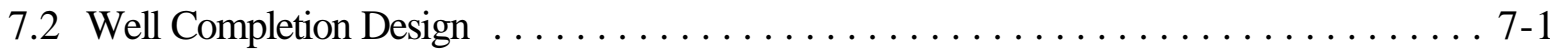

7.2.1 Proposed Completion Design $\ldots \ldots \ldots \ldots \ldots \ldots \ldots \ldots \ldots \ldots \ldots \ldots \ldots \ldots \ldots \ldots$

7.2.2 As-Built Completion Design .............................. 7-5

7.2.3 Rationale for Differences between Actual and Proposed Well Design ........ . 7-6

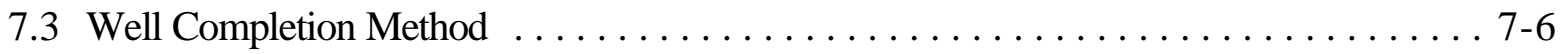

8.0 Actual versus Planned Costs and Scheduling $\ldots \ldots \ldots \ldots \ldots \ldots \ldots \ldots \ldots \ldots \ldots \ldots \ldots \ldots \ldots \ldots$

9.0 Summary, Recommendations, and Lessons Learned $\ldots \ldots \ldots \ldots \ldots \ldots \ldots \ldots$ 9-1

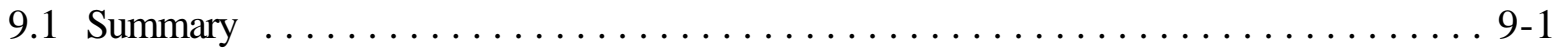

9.2 Recommendations ................................. $9-2$

9.3 Lessons Learned . . . . . . . . . . . . . . . . . . . . . . . . . . . 9-2

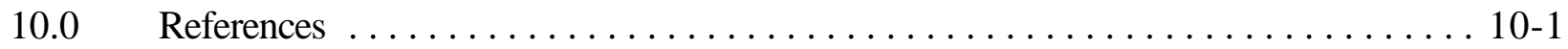

Appendix A - Drilling Data

A-1 Drilling Parameter Log for Well ER-EC-5

A-2 Casing Data for Well ER-EC-5

A-3 Well ER-EC-5 Drilling Fluids and Cement Composition

Appendix B - Well ER-EC-5 Fluid Management Data

Fluid Disposition Reporting Forms for Well ER-EC-5

Preliminary Analytical Results for Fluid Management Samples at Well ER-EC-5

Appendix C - Detailed Lithologic Log for Well ER-EC-5

Appendix D - Well ER-EC-5 Geophysical Logs

Distribution List 


\section{List of Figures}

Number

Title

Page

1-1 Reference Map Showing Location of Well ER-EC-5 . . . . . . . . . . . . 1-3

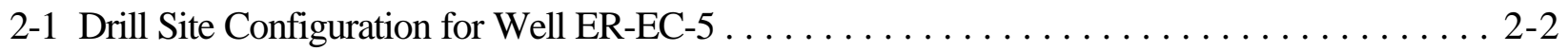

2-2 Well ER-EC-5 Drilling and Completion History $\ldots \ldots \ldots \ldots \ldots \ldots \ldots \ldots \ldots \ldots$

4-1 Map of Western Pahute Mesa - Oasis Valley Area Showing Theorized Locations

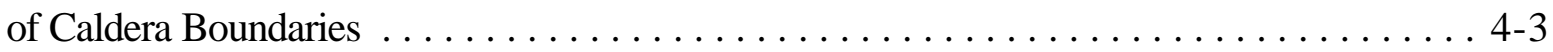

4-2 Geologic Map of the Well ER-EC-5 Site $\ldots \ldots \ldots \ldots \ldots \ldots \ldots \ldots \ldots \ldots \ldots$

4-3 Geology and Hydrogeology of Well ER-EC-5 . . . . . . . . . . . . . . . 4-9

4-4 Geologic Cross Section A-A' Through Well ER-EC-5 . . . . . . . . . . . . . . . 4-13

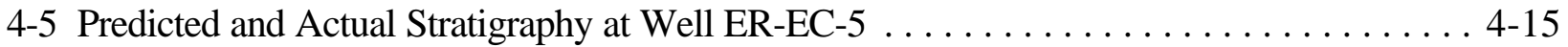

4-6 Hydrogeologic Cross Section B-B' Through Well ER-EC-5 . . . . . . . . . . . . . . 4-17

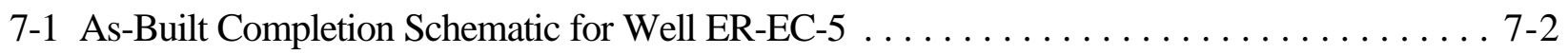

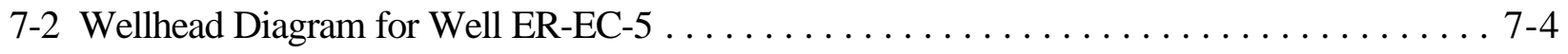

8-1 Planned versus Actual Construction Progress for Well ER-EC-5 . . . . . . . . . . 8-2

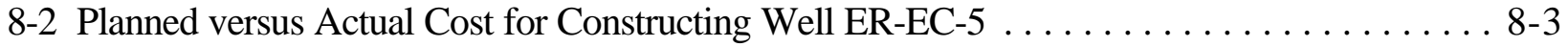




\section{List of Tables}

Number

Title

Page

1-1 Well ER-EC-5 Site Data Summary .............................. 1-5

2-1 Abridged Drill Hole Statistics for Well ER-EC-5 . . . . . . . . . . . . . . . . . . 2-5

3-1 Sidewall Core Samples from Well ER-EC-5 . . . . . . . . . . . . . . . . . . . . 3-3

3-2 Status of Rock Sample Analyses for Well ER-EC-5 … . . . . . . . . . . . . 3-4

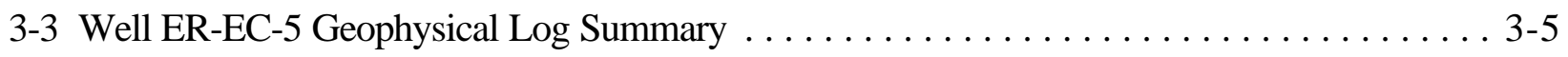

7-1 Well ER-EC-5 Completion String Construction Summary $\ldots \ldots \ldots \ldots \ldots \ldots \ldots \ldots . \ldots \ldots . \ldots \ldots$

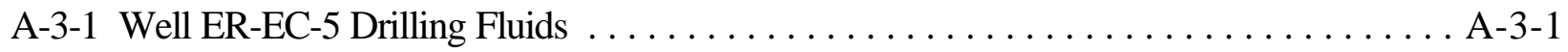

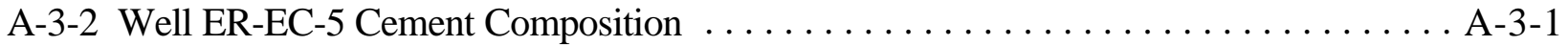

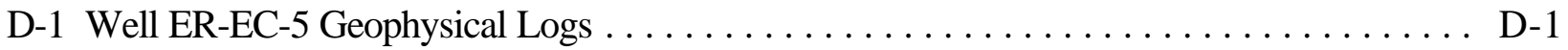




\section{List of Acronyms and Abbreviations}

\begin{tabular}{|c|c|}
\hline BHA & bottom-hole assembly \\
\hline $\mathrm{BN}$ & Bechtel Nevada \\
\hline $\mathrm{C}$ & Celsius \\
\hline $\mathrm{cm}$ & centimeter(s) \\
\hline DOE & U.S. Department of Energy \\
\hline DRI & Desert Research Institute \\
\hline $\mathrm{E}$ & East \\
\hline $\mathrm{EC}$ & Electrical Conductivity \\
\hline $\mathrm{F}$ & Fahrenheit \\
\hline FMP & Fluid Management Plan \\
\hline $\mathrm{ft}$ & foot (feet) \\
\hline gpm & gallons per minute \\
\hline in. & inch(es) \\
\hline IT & IT Corporation \\
\hline $\mathrm{km}$ & kilometer(s) \\
\hline lpm & liters per minute \\
\hline LANL & Los Alamos National Laboratory \\
\hline $\mathrm{LiBr}$ & lithium bromide \\
\hline $\mathrm{m}$ & meter(s) \\
\hline $\mathrm{Ma}$ & million years ago \\
\hline $\mathrm{mi}$ & mile(s) \\
\hline $\mathrm{N}$ & North \\
\hline NAD & North American Datum \\
\hline NNSA/NSO & $\begin{array}{l}\text { U.S. Department of Energy, National Nuclear Security Administration Nevada } \\
\text { Site Office }\end{array}$ \\
\hline NTS & Nevada Test Site \\
\hline $\mathrm{TD}$ & total depth \\
\hline TFM & Thermal Flow Meter \\
\hline TMCC & Timber Mountain caldera complex \\
\hline TWG & Technical Working Group \\
\hline UDI & United Drilling, Inc. \\
\hline UGTA & Underground Test Area \\
\hline USGS & United States Geological Survey \\
\hline WPM-OV & Western Pahute Mesa - Oasis Valley \\
\hline
\end{tabular}


This page intentionally left blank. 


\subsection{Introduction}

\subsection{Project Description}

Well ER-EC-5 was drilled for the U.S. Department of Energy (DOE), National Nuclear Security Administration Nevada Site Office (NNSA/NSO; formerly Nevada Operations Office, DOE/NV) in support of the Nevada Environmental Restoration Project at the Nevada Test Site (NTS), Nye County, Nevada. Well ER-EC-5 is the fifth in a series of wells to be drilled as part of the hydrogeologic investigation well program in the Western Pahute Mesa - Oasis Valley (WPM-OV) region of Nye County, Nevada. This program is part of the NNSA/NSO Environmental Restoration Division's Underground Test Area (UGTA) Project at the NTS. The goals of the UGTA project include evaluating the nature and extent of contamination in groundwater due to underground nuclear testing, and establishing a long-term groundwater monitoring network. As part of the UGTA project, scientists are developing computer models to predict groundwater flow and contaminant migration within and near the NTS. To build and test these models, it is necessary to collect geologic, geophysical, and hydrologic data from new and existing wells to define groundwater migration pathways, migration rates, and quality.

The goal of the WPM-OV program is to collect subsurface geologic and hydrologic data in a large, poorly characterized area down-gradient from Pahute Mesa where underground nuclear tests were conducted, and up-gradient from groundwater discharge and withdrawal sites in Oasis Valley northeast of Beatty, Nevada (Figure 1-1). Data from these wells will allow for more accurate modeling of groundwater flow and radionuclide migration in the region. Some of the wells may also function as long-term monitoring wells.

Well ER-EC-5 is located within the Nellis Air Force Range complex, approximately 10.5 kilometers (km) (6.5 miles [mi]) west of the NTS (Figure 1-1), in the Timber Mountain caldera complex, near the western structural margin of the Ammonia Tanks caldera. The elevation of the dirt-fill drill pad at the wellhead is $1,547.5$ meters $(\mathrm{m})(5,077.0$ feet [ft]) above mean sea level. The Nevada State Planar coordinates (North American Datum [NAD] 1983) at the wellhead are North (N) 6,259,008.5 and East (E) 508,998.3 m (N 20,534,763.8, E 1,669,938.7 ft). Additional site data are listed in Table 1-1.

IT Corporation (IT) was the principal environmental contractor for the project, and IT personnel collected geologic and hydrologic data during drilling. The drilling company was United Drilling, Incorporated (UDI), a subcontractor to Bechtel Nevada (BN). Site supervision, engineering, 
This page intentionally left blank. 


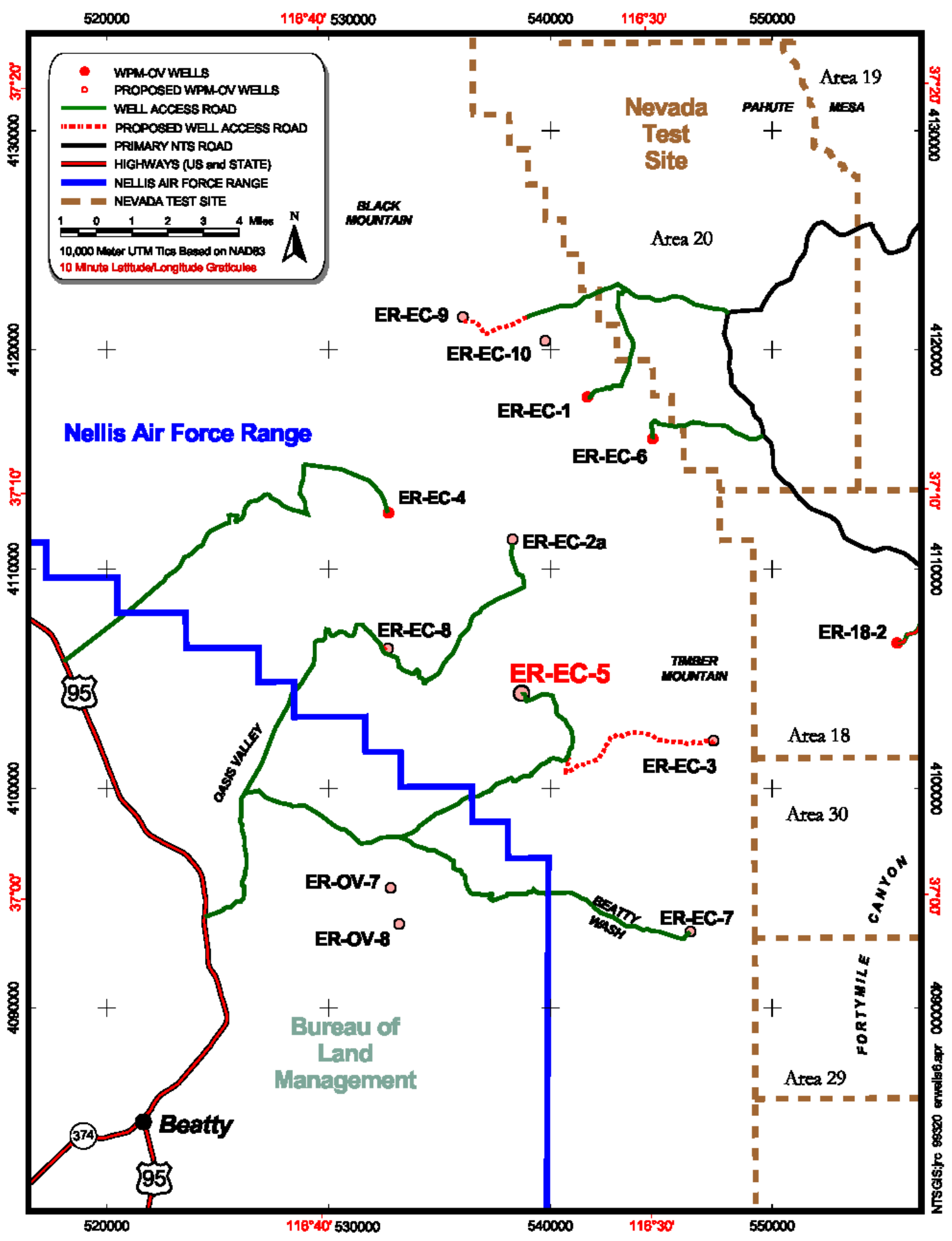

Figure 1-1

Reference Map Showing Location of Well ER-EC-5

(Proposed wells not drilled at time Well ER-EC-5 was drilled.) 
This page intentionally left blank. 
Table 1-1

Well ER-EC-5 Site Data Summary

\begin{tabular}{|c|c|}
\hline Well Designation & ER-EC-5 \\
\hline Site Coordinates ${ }^{a}$ & $\begin{array}{l}\text { Central Nevada State Planar (NAD 83): } \\
\begin{array}{l}\text { N 6,259,008.5 m (N 20,534,763.8 ft) } \\
\text { E 508,998.3 m (E 1,669,938.7 ft) }\end{array} \\
\text { Central Nevada State Planar (NAD 27): } \\
\text { N 849,762.4 ft } \\
\text { E 529,783.0 ft } \\
\text { Universal Transverse Mercator (Zone 11)(NAD 83): } \\
\text { N 4,104,333.9 m } \\
\text { E 538,621.6 m }\end{array}$ \\
\hline Surface Elevation ${ }^{b}$ & $1,547.5 \mathrm{~m}(5,077.0 \mathrm{ft})$ \\
\hline Drilled Depth & $762.0 \mathrm{~m}(2,500 \mathrm{ft})$ \\
\hline Fluid-Level Depth ${ }^{c}$ & $309.9 \mathrm{~m}(1,016.8 \mathrm{ft})$ \\
\hline Fluid-Level Elevation & $1,237.5 \mathrm{~m}(4,060.2 \mathrm{ft})$ \\
\hline
\end{tabular}

a Measurement BN Survey.

b Measurement by BN Survey. Elevation at top of drill pad. 1929 National Geodetic Vertical Datum.

C Measured by IT on August 19, 1999, approximately 40 days after completion string was installed

(IT, 1999).

construction, inspection, and geologic support were provided by BN. The roles and responsibilities of these and other contractors involved in the project are described in Contract Number

DE-RP-08-95NV11808 and in BN Drilling Work Plan Number D-006-002.99 (BN, 1999b). The UGTA Technical Working Group (TWG), a committee of scientists and engineers comprising NNSA/NSO, Lawrence Livermore National Laboratory, Los Alamos National Laboratory (LANL), and contractor personnel, provided additional technical advice during drilling, design, and construction of the well. See FY99 Western Pahute Mesa-Oasis Valley Hydrogeologic Investigation Wells Drilling and Completion Criteria (IT, 1998) for descriptions of the general plan and goals of the WPM-OV project, as well as specific goals for each planned well.

General guidelines for managing fluids used and generated during drilling, completion, and testing of UGTA wells are provided in the UGTA Fluid Management Plan (FMP) (DOE, 1996a), an attachment to the UGTA Waste Management Plan (DOE, 1996b). Estimates of fluid and cuttings production for the WPM-OV holes are given in Appendix $\mathrm{N}$ of the drilling and completion criteria document for the WPM-OV project (IT, 1998), along with sampling requirements and contingency plans for management of any hazardous waste produced. All activities were conducted according to the Nevada 
Environmental Restoration Project Health and Safety Plan (DOE, 1998) and the Site-Specific Health and Safety Plan for WPM-OV Investigation Wells (BN, 1999a).

This report presents construction data and summarizes scientific data gathered during drilling and installation of the completion string in Well ER-EC-5. A preliminary well data report prepared by IT (IT, 1999) contains additional information on fluid management, waste management, and environmental compliance. Information on well development, aquifer testing, and groundwater analytical sampling will be compiled and disseminated after any such work is performed.

\subsection{Objectives}

The primary purpose of Well ER-EC-5 is to provide information about hydrostratigraphic units, geologic structures, and bulk hydraulic properties in this part of the WPM-OV area. Well-specific scientific objectives, as discussed in Appendix E of the drilling criteria document (IT, 1998), include the following:

! Provide hydrogeologic information on the east side of a geophysically inferred, north-northeast striking structure which may be a hydraulic barrier.

! Investigate the effects that rocks filling the moat of the Timber Mountain caldera have on local groundwater flow.

Some of these objectives will not be met until additional work, outside the scope of this report, is completed, including installing a pump and conducting hydraulic testing, and analyzing geology and hydrology data from this and other planned wells in the WPM-OV area.

\subsection{Project Summary}

This section summarizes Well ER-EC-5 construction operations; the details are provided in sections 2 through 8 of this report.

The surface conductor hole was prepared in June 1999, by augering a 91.4-centimeter $(\mathrm{cm})(36-i n c h$ [in.]) hole to a depth of $10.7 \mathrm{~m}(35 \mathrm{ft})$ and then deepening the hole to $21.8 \mathrm{~m}(71.5 \mathrm{ft})$ at a diameter of $66.0 \mathrm{~cm}$ (26 in.). A section of 20-in. conductor casing was set at $21.3 \mathrm{~m}$ (70.0 ft) below ground level, and cementing was completed on June 10, 1999.

Drilling of the main hole with a 171/2-in. rotary bit, using air-foam and polymer in conventional (direct) circulation, began on June 24, 1999, after completion of Well ER-EC-4. A suitable depth to set casing 
was reached at $346.3 \mathrm{~m}$ (1,136 ft). At this point, drilling was suspended for geophysical logging, and then $13 \mathrm{~d}$-in. surface casing was landed at the depth of $342.6 \mathrm{~m}(1,124.1 \mathrm{ft})$, approximately $32.7 \mathrm{~m}$ $(107.3 \mathrm{ft})$ below the static water level. Drilling continued with a 121/4-in. bit to a total depth (TD) of $762.0 \mathrm{~m}(2,500 \mathrm{ft})$, which was reached on July 4, 1999.

Water production was first noted at the depth of approximately $306.9 \mathrm{~m}(1,007 \mathrm{ft})$, and reached a maximum of over 4,542 liters per minute (lpm) (1,200 gallons per minute [gpm]) near the bottom of the hole. The preliminary, composite static water level prior to installation of the completion string was approximately $310.3 \mathrm{~m}$ (1,018 ft) below ground surface. On August 19, 1999, over a month after installation of the completion string, the fluid level was tagged by IT at a depth of $309.9 \mathrm{~m}(1,016.8 \mathrm{ft})$. No radionuclides above natural background levels were encountered during drilling of Well ER-EC-5.

Composite drill cuttings were collected every $3.0 \mathrm{~m}$ (10 ft) from $21.3 \mathrm{~m}$ (70 ft) to TD, and 18 sidewall core samples were taken at various depths below $349.6 \mathrm{~m}(1,147 \mathrm{ft})$. Open-hole geophysical logging of the well was conducted to help verify the geology and characterize the hydrology of the rocks; some logs also aided in the construction of the well by indicating borehole volume and condition, and cement location. The well penetrated Tertiary-age tuffs of the Thirsty Canyon Group, caldera moat-filling sedimentary deposits, lava of the Beatty Wash Formation, and landslide breccia and tuffs of the Timber Mountain Group. Welded ash-flow tuff of the Ammonia Tanks Tuff, penetrated in the lowest $440.1 \mathrm{~m}$ $(1,444 \mathrm{ft})$ of the well, was the main water-producing unit.

A single completion string was installed in Well ER-EC-5 on July 9, 1999. Stainless steel, 51/2-in. production casing was landed at $746.5 \mathrm{~m}(2,449.0 \mathrm{ft})$. The bull-nosed string has three slotted intervals, at 684.5 to $736.8 \mathrm{~m}$ (2,245.7 to $2,417.2 \mathrm{ft}), 576.8$ to $638.3 \mathrm{~m} \mathrm{(1,892.4} \mathrm{to} \mathrm{2,094.0} \mathrm{ft),} \mathrm{and} 364.7$ to $426.3 \mathrm{~m}$ (1,196.6 to $1,398.5 \mathrm{ft})$. Internally epoxy-coated, $7 \mathrm{e}$-in. carbon-steel casing extends (via a crossover sub) from the top of the $51 \frac{1}{2}$-in. casing at $352.4 \mathrm{~m}(1,156.2 \mathrm{ft})$ to the ground surface. The completion string was gravel-packed across the slotted intervals, and the remaining annular space was sealed with sand and cement to $219.5 \mathrm{~m}$ (720 ft) on July 10, 1999. No pump was installed at the time of completion. 


\subsection{Project Manager}

Inquiries concerning Well ER-EC-5 should be directed to the UGTA Project Manager at:

U.S. Department of Energy

National Nuclear Security Administration

Nevada Site Office

Environmental Restoration Division

Post Office Box 98518

Las Vegas, Nevada 89193-8518 


\subsection{Drilling Summary}

This section contains detailed descriptions of the drilling process and fluid management issues.

\subsection{Introduction}

The general drilling requirements for all WPM-OV wells are described in FY99 Western Pahute Mesa-Oasis Valley Hydrogeologic Investigation Wells Drilling and Completion Criteria (IT, 1998), which also includes criteria for Well ER-EC-5 in Appendix E. Specific requirements for Well ER-EC-5 are outlined in Drilling Work Plan Number D-006-002.99 (BN, 1999b). The following information was compiled primarily from $\mathrm{BN}$ daily drilling reports. Figure 2-1 shows the layout of the drill site. Figure 2-2 is a chart of the drilling and completion history for Well ER-EC-5. A summary of drilling statistics for the well is given in Table 2-1. Fluid management information (Section 2.4) was obtained primarily from IT's preliminary well data report (IT, 1999).

\subsection{Drilling History}

Field operations at Well ER-EC-5 began on June 3, 1999, when a BN crew rigged up the "Auger 2"

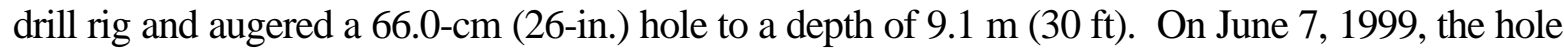

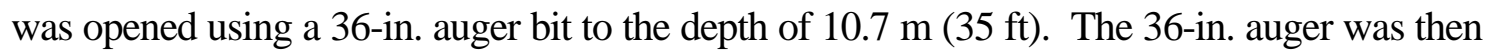
exchanged for the 26-in. auger, and drilling continued to the depth of $21.8 \mathrm{~m}(71.5 \mathrm{ft})$. On June 10, 1999, a section of 20-in. conductor casing was set at a depth of $221.3 \mathrm{~m} \mathrm{(70.0} \mathrm{ft).} \mathrm{The}$

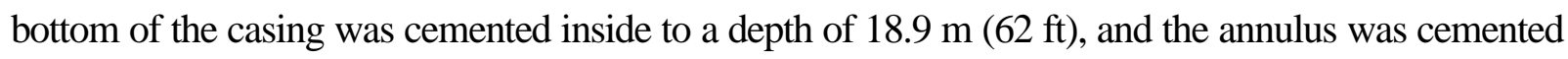
from the bottom of the casing up to ground level on the same day. The auger rig was then moved off location.

Preparations for the drilling of the main hole, including delivering and setting up equipment on site, began June 21, 1999. A Wilson Mogul 42B drilling rig was mobilized to the Well ER-EC-5 site, and the UDI crew made up a bottom-hole assembly (BHA) with a 171/2-in rotary bit; drilling began on June 24, 1999. Cement inside the conductor casing was drilled from the depth of $18.9 \mathrm{~m}(62.0 \mathrm{ft})$ to $21.8 \mathrm{~m}$ $(71.5 \mathrm{ft})$ where rock was encountered. Conventional circulation was used with compressed air, water and soap (i.e., air-foam), and polymer drilling fluid. The amounts of soap and polymer in the airfoam/polymer mix and the fluid injection rate were adjusted as necessary during drilling to maintain superior circulation and penetration rate, and to minimize borehole sloughing. 


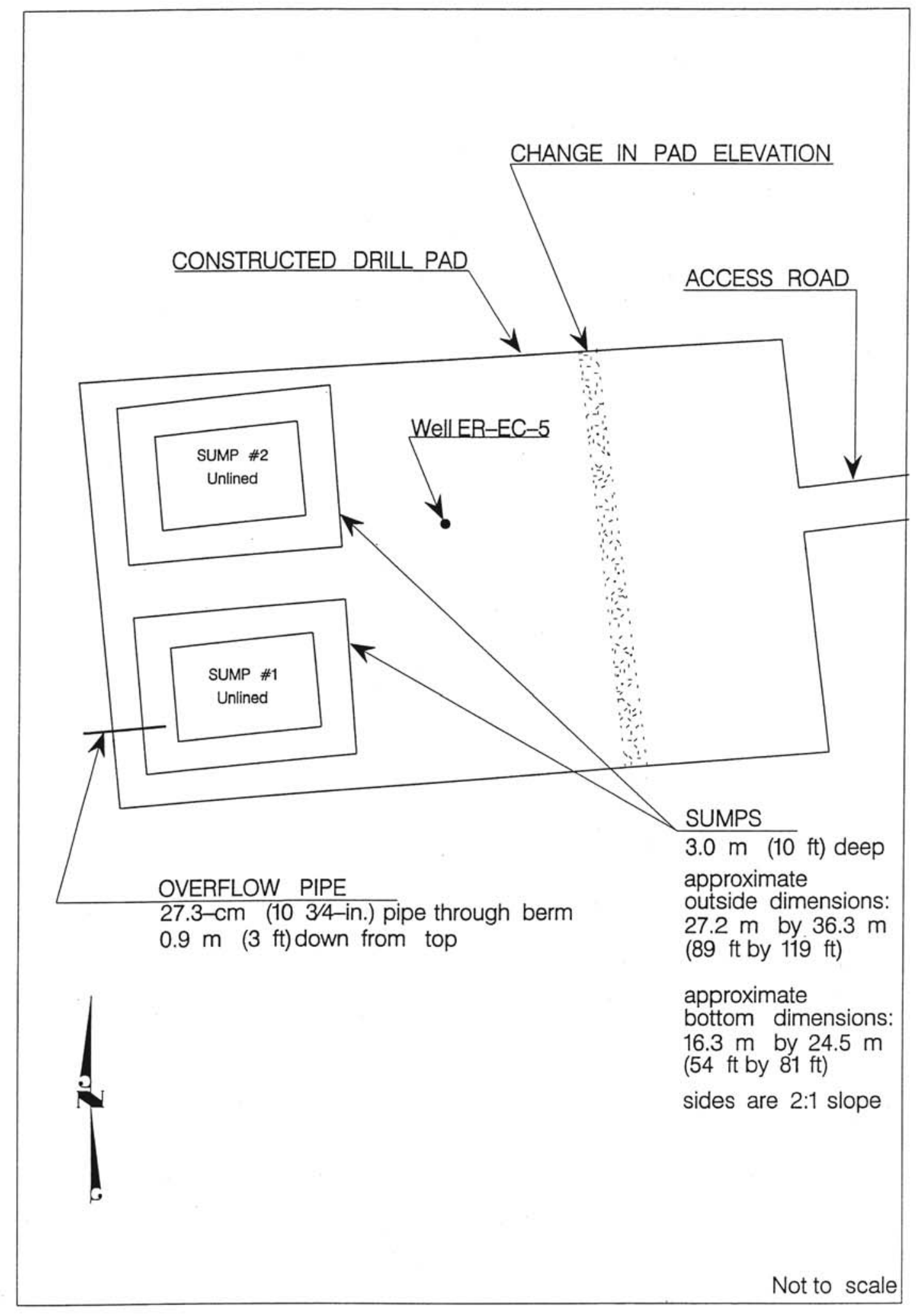

Figure 2-1

Drill Site Configuration for Well ER-EC-5 


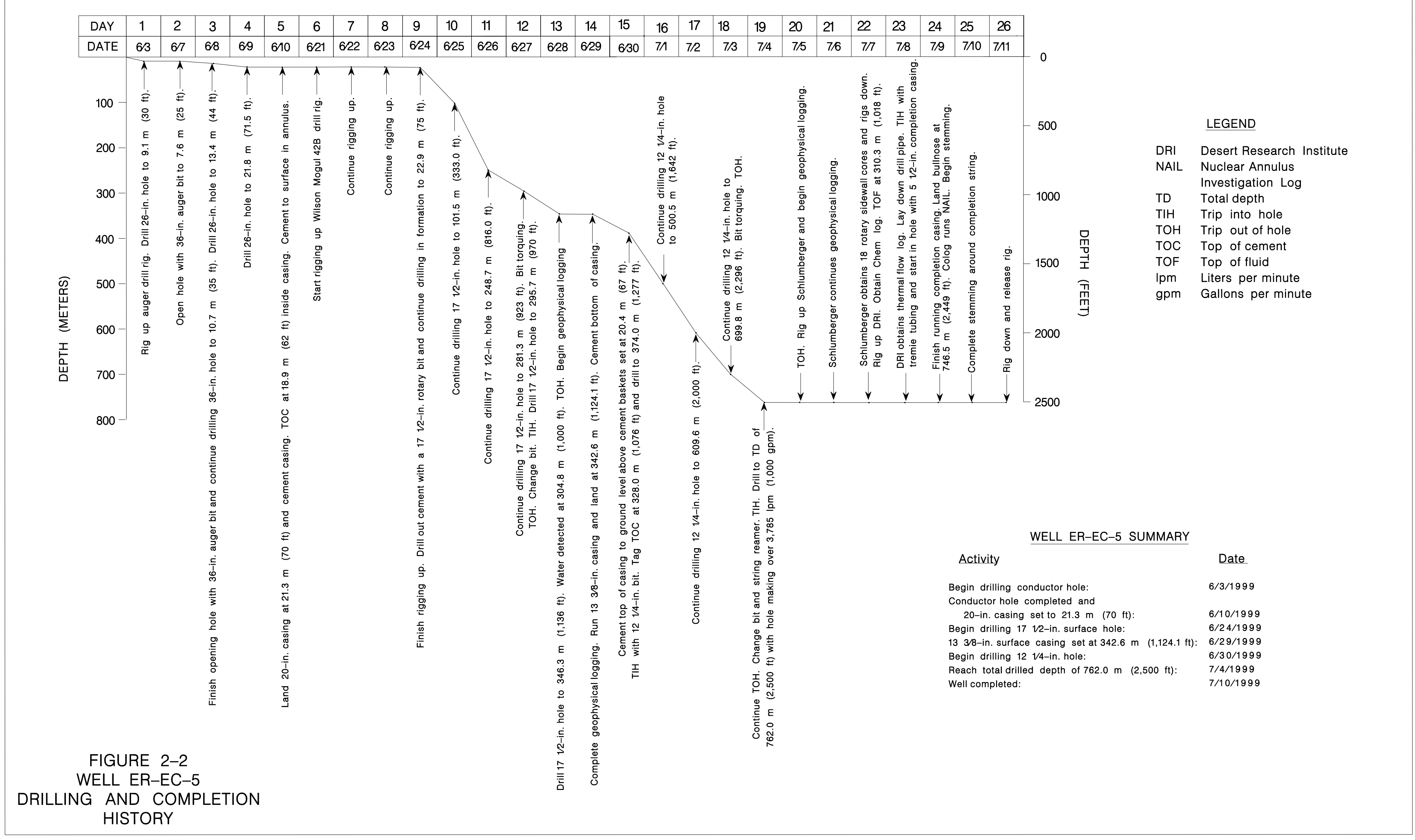


This page intentionally left blank. 
Table 2-1

Abridged Drill Hole Statistics for Well ER-EC-5

LOCATION DATA:

Coordinates:
Central Nevada State Planar: NAD 83: N 6,259,008.5 E 508,998.3 m NAD 27: N 849,762.4 E 529,783.0 ft

NAD 83: N 4,104,333.9 E 538,621.6 m

Universal Transverse Mercator:

Surface Elevation ${ }^{\text {a: }}$

$1,547.5 \mathrm{~m}(5,077.0 \mathrm{ft})$

DRILLING DATA:

Spud Date:

Total Depth (TD):

Date TD Reached:

Date Well Completed ${ }^{\text {b: }}$

Hole Diameter:

Hole Diameter:

6/24/1999 (main hole with Wilson Mogul 42B rig)

$762.0 \mathrm{~m}(2,500 \mathrm{ft})$

$7 / 4 / 1999$

$7 / 11 / 1999$

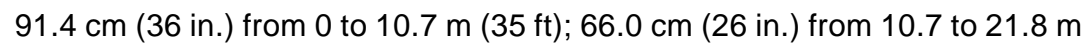
(35 to $71.5 \mathrm{ft}) ; 44.4 \mathrm{~cm}(17.5 \mathrm{in}$.) from 21.8 to $346.3 \mathrm{~m}(71.5$ to $1,136 \mathrm{ft})$; $31.1 \mathrm{~cm}(12.25 \mathrm{in}$.) from $346.3 \mathrm{~m}(1,136 \mathrm{ft})$ to TD of $762.0 \mathrm{~m}(2,500 \mathrm{ft})$.

Drilling Techniques: Dry-hole auger from surface to $21.8 \mathrm{~m}(71.5 \mathrm{ft}$ ) ; rotary drilling with $171 / 2$-in. bit and air-foam/polymer in direct circulation from 21.8 to $346.3 \mathrm{~m}$ (71.5 to $1,136 \mathrm{ft}$ ), and with $12^{1 / 4}$-in. bit from 346.3 to $762.0 \mathrm{~m}$ (1,136 to $\left.2,500 \mathrm{ft}\right)(\mathrm{TD})$.

CASING DATA:

20 -in. conductor casing from surface to $21.3 \mathrm{~m}(70.0 \mathrm{ft}$.); $13 \mathrm{~d}$-in. surface casing from surface to $342.6 \mathrm{~m}(1,124.1 \mathrm{ft})$.

\section{WELL COMPLETION DATA:}

The completion string consists of $7 \mathrm{e}$-in. carbon-steel casing with an internal epoxy coating, connected to $5 \frac{1}{2}-$-in. stainless-steel casing via an internally coated carbon-steel crossover sub. The carbon-steel

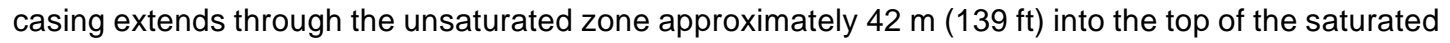
zone. The $14.0-\mathrm{cm}\left(5 \frac{1}{2}\right.$-in.) outside-diameter casing has a $12.83-\mathrm{cm}(5.05-\mathrm{in}$.) inside diameter, is bullnosed, and has three slotted intervals that each consist of alternating blank and slotted joints.

Detailed data for the completion intervals are provided in Section 7 of this report.

Total Depth: $\quad 746.5 \mathrm{~m}(2,449 \mathrm{ft})$

Depth of Slotted Sections: $\quad 364.7$ to $426.3 \mathrm{~m}$ $(1,196.6$ to $1,398.5 \mathrm{ft})$

576.8 to $638.3 \mathrm{~m}$ $(1,892.4$ to $2,094.0 \mathrm{ft})$

684.5 to $736.8 \mathrm{~m}$ $(2,245.7$ to $2,417.2 \mathrm{ft})$

Depth of Sand Pack: $\quad 356.3$ to $361.8 \mathrm{~m}$ $(1,169$ to $1,187 \mathrm{ft})$

Depth of Gravel Pack: $\quad 361.8$ to $440.1 \mathrm{~m}$ $(1,187$ to $1,444 \mathrm{ft})$
559.3 to $565.4 \mathrm{~m}$ $(1,835$ to $1,855 \mathrm{ft})$

565.4 to $654.1 \mathrm{~m}$ $(1,855$ to $2,146 \mathrm{ft})$
668.7 to $677.6 \mathrm{~m}$ $(2,194$ to $2,223 \mathrm{ft})$

677.6 to $755.9 \mathrm{~m}$

$(2,223$ to $2,480 \mathrm{ft})$

Depth of Pump: None installed at time of completion.

Water Depth: ${ }^{d}$

$309.9 \mathrm{~m}(1,016.8 \mathrm{ft})$

DRILLING CONTRACTOR: United Drilling, Inc.

GEOPHYSICAL LOGS BY: Barbour Well Surveying, Schlumberger Logging Services, Colog, Inc. Desert Research Institute, Gyrodata

SURVEYING CONTRACTOR: Bechtel Nevada

a Elevation of ground level at wellhead. 1929 National Geodetic Vertical Datum.

b Date completion string was cemented. Pump will be installed as needed.

c Gravel adjacent to slotted intervals only. Additional gravel layers were used as stemming outside blank casing sections. See Table 7-1.

d Measured on August 19, 1999, 40 days after completion string was installed (IT, 1999). 
Drilling was slow between the depths of 247 and $305 \mathrm{~m}(810$ and 1,000 ft) as various intervals of gravel and landslide breccia were encountered. At the depth of $281.3 \mathrm{~m}$ (923 ft), on June 27, 1999, the penetration rate slowed considerably and the bit began torquing, so the bit was replaced. Drilling continued to be slow until thick sections of bedded and ash-flow tuff were encountered below $305.4 \mathrm{~m}$ $(1,002 \mathrm{ft})$. The first significant water production was noted at a depth of approximately $306.9 \mathrm{~m}$ $(1,007 \mathrm{ft})$.

As a precaution against sloughing of the upper section of unsaturated volcanic rocks, it was planned to install surface casing when a competent formation for supporting the casing was reached. The bottom of the surface hole was reached in moderately welded ash-flow tuff at $346.3 \mathrm{~m}(1,136 \mathrm{ft})$ on June 28, 1999. The drillers circulated fluid to condition the hole for 30 minutes, then pulled four stands of pipe and waited 30 minutes before tagging bottom again. Only $0.6 \mathrm{~m}(2 \mathrm{ft})$ of fill was found, so the drillers pulled the drilling tools out of the hole. Drilling was suspended for approximately 20 hours during geophysical logging prior to installation of casing.

A casing subcontractor landed $13 \mathrm{~d}$-in. casing with centralizers installed above the guide shoe, at the middle and top of the first joint, and at the top of the second joint. A float collar was installed between the first and second joints. Two metal-petal cement baskets are located at $20.4 \mathrm{~m}$ (67.0 ft) below ground level. The casing was landed at $342.6 \mathrm{~m}$ (1,124.1 ft.) on June 29, 1999, and pre-flush clear water was pumped down the casing prior to cementing. A stab-in sub was seated in the float collar, and type II Portland cement was pumped inside the casing through the stab-in sub, followed by water to displace the cement. The annulus above the cement baskets was cemented to ground level in five stages, using a mix of cement and sand ("75/25"). Cementing of the surface casing was completed on June 30, 1999. The top of cement in the casing annulus was later determined from geophysical logs to be at the depth of $225.9 \mathrm{~m}$ (741 ft). The top of cement inside the casing was tagged at $328.0 \mathrm{~m}$ $(1,076 \mathrm{ft})$ when drilling resumed.

A BHA made up with a 121/4-in. bit was used to drill the remainder of the borehole. Cement was drilled from 328.0 to $342.9 \mathrm{~m}$ (1,076 to $1,125 \mathrm{ft}$ ), and drilling continued through $3.4 \mathrm{~m}(11 \mathrm{ft})$ of fill before entering the formation. The bit was replaced again at the depth of $699.8 \mathrm{~m}(2,296 \mathrm{ft})$, and drilling of the 31.1-cm (12.25-in.) hole continued without major problems to the TD of $762.0 \mathrm{~m}$ (2,500 ft), reached on July 4, 1999.

Immediately after reaching TD, the drillers circulated fluid for an hour to condition the hole before the second phase of geophysical logging, which took place July 5 to 8, 1999. Installation of the completion 
string began on July 8, 1999. Demobilization from the Well ER-EC-5 site began after gravel-packing and cementing were completed on July 11, 1999.

A directional survey was run in the completion string of Well ER-EC-5 on October 19, 1999. The survey indicates that at the lowest surveyed depth of $737.3 \mathrm{~m}(2,419.0 \mathrm{ft})$, the hole had drifted $4.2 \mathrm{~m}$ $(13.9 \mathrm{ft})$ to the east-southeast of the collar location. The hole is relatively straight, with no severe "dog legs."

A graphical depiction of drilling parameters including penetration rate, revolutions per minute, pump pressure, and weight on the bit is presented in Appendix A-1. See Appendix A-2 for a listing of casing materials. Drilling fluids and cements used in Well ER-EC-5 are listed in Appendix A-3.

\subsection{Drilling Problems}

No significant problems were encountered during the drilling of Well ER-EC-5. The rate of penetration was generally low between about $248.7 \mathrm{~m}(816 \mathrm{ft})$ and $304.8 \mathrm{~m}(1,000 \mathrm{ft})$ within an interval of gravel deposits and landslide breccias. Fluid circulation was temporarily lost at the depths of 163.4 and $751.3 \mathrm{~m}$ (536 and 2,465 ft), but was regained when the amounts of soap and polymer in the drilling fluid were increased, and the injection rate was increased.

Fill encountered (due to sloughing of the borehole wall) was minimal. No fill was found on most connections, though up to $1.5 \mathrm{~m}(5 \mathrm{ft})$ of fill was encountered on a few connections, and $3.4 \mathrm{~m}(11 \mathrm{ft})$ of fill was encountered when drilling resumed after cementing of the $13 \mathrm{~d}$-in casing. This sloughing did not result in significant drilling delays. However, an obstruction (or "bridge") was encountered at the depth of $501.7 \mathrm{~m}$ (1,646 ft) during geophysical logging. The drillers used the drill bit to push the material to the bottom of the borehole, where approximately $6.1 \mathrm{~m}(20 \mathrm{ft})$ of fill remained prior to installation of the completion string.

\section{$2.4 \quad$ Fluid Management}

Drilling effluent was monitored according to the methods prescribed in the UGTA FMP (DOE, 1996a). The air-foam/polymer drill fluid was circulated down the inside of the drill string and back up the hole through the annulus ("conventional" circulation) and then discharged into a sump. Water used to prepare drilling fluids came from the Coffer Well located approximately $16 \mathrm{~km}$ (10 mi) north-northeast of Beatty, and a lithium bromide ( $\mathrm{LiBr})$ tracer was added as a means of estimating groundwater production. 
To manage the expected high water production, two unlined sumps were constructed prior to drilling (Figure 2-1). One of the sumps was to be lined with plastic if concentrations of radionuclides or other contaminants in the fluid exceeded FMP requirements. Samples of drilling effluent were tested hourly for the presence of tritium, and every eight hours for lead. Monitoring results indicated tritium at natural background levels and no detectable lead, so the sumps were left unlined. Samples from the sumps were also analyzed by an off-site facility during and after drilling to verify on-site analyses and to demonstrate compliance with the FMP.

On July 1, 1999, fluid discharge was diverted from sump 1 to sump 2 (before the fluid level in sump 1 reached the overflow pipe), pending the results of the analysis of a fluid sample taken from the sump. The analysis showed values for analytes below the allowable FMP discharge levels, so on July 3, 1999, when both sumps were full, discharge was again routed to sump 1. Fluid was allowed to flow through the overflow pipe to the ground surface after sump fluid analysis results were relayed to the Nevada Division of Environmental Protection. Water-quality data from the FMP samples are given in Appendix B.

The results of analyses of samples of drilling fluid collected at Well ER-EC-5 during drilling operations indicate that all fluid quality objectives were met, as shown on the fluid management reporting form dated November 23, 1999 (Appendix B). The form lists volumes of solids (drill cuttings) and fluids produced during well-construction operations, Stages I and II (vadose- and saturated-zone drilling; well development and aquifer testing will be conducted at a later date). The volume of solids produced was calculated using the diameter of the borehole (from caliper logs) and the depth drilled, and includes added volume attributed to a rock bulking factor. The volume of fluid listed on the report is an estimate of total fluid production, and does not account for any infiltration or evaporation of fluids from the sumps. 


\subsection{Geologic Data Collection}

\subsection{Introduction}

This section describes the sources of geologic data obtained from Well ER-EC-5 and the methods of data collection. Improving the understanding of the subsurface structure, stratigraphy, and hydrogeology of the area southwest of Pahute Mesa was among the primary objectives of Well ER-EC-5, so the proper collection of geologic and hydrogeologic data from Well ER-EC-5 was considered fundamental to successful completion of the project.

Geologic data collected at Well ER-EC-5 consist of drill cuttings, sidewall core samples, and geophysical logs. Data collection, sampling, transfer, and documentation activities were performed according to applicable contractor procedures.

\subsection{Collection of Drill Cuttings}

Composite drill cuttings were collected from Well ER-EC-5 at 3.05-m (10-ft) intervals as drilling progressed from the depth of $21.3 \mathrm{~m}(70 \mathrm{ft})$ to the TD of the well at $762.0 \mathrm{~m}(2,500 \mathrm{ft})$. Triplicate samples were collected from 243 intervals and, in addition, the IT field representative collected two sets of reference samples from each of the cuttings intervals. One set was examined at the drill site for use in preparing field lithologic descriptions, and remains in the custody of Stoller-Navarro Joint Venture, the current environmental contractor for NNSA/NSO and IT's successor. The other set was sent to R. G. Warren (LANL), where it remains. All other samples (i.e., three sets of 243 samples) are stored under secure, environmentally controlled conditions at the U.S. Geological Survey (USGS) Geologic Data Center and Core Library in Mercury, Nevada. One of these sample sets was sealed with custody tape at the rig site and remains sealed as an archive sample; one set was left unsealed in the original sample containers; and the third set was washed and stored according to standard USGS Core Library procedures.

\subsection{Sidewall Core Samples}

No sidewall sampling was attempted from the surface hole at Well ER-EC-5 before installation of 13d -in. surface casing. On July 7, 1999, after TD was reached and before the completion string was installed, Schlumberger collected sidewall samples with a rotary coring tool. Eighteen samples were successfully collected out of 20 attempted between 349.6 and $745.2 \mathrm{~m}$ (1,147 and 2,445 ft). Sample locations were selected by the IT Field Representative on the basis of field lithologic logs (with consideration of borehole conditions determined from caliper logs) to obtain adequate representation of the rocks encountered below the depth of $346.3 \mathrm{~m}$ (1,136 ft). These samples will help verify the 
stratigraphy and lithology penetrated. A list of samples, including sample recovery and the stratigraphic assignment of each sample, is given in Table 3-1.

\subsection{Sample Analysis}

Twenty-three samples of drill cuttings from various depths in Well ER-EC-5 were submitted to the LANL Earth and Environmental Sciences Division - Geology and Geochemistry laboratories for petrographic, mineralogic, and chemical analyses to aid in stratigraphic identification and for characterization of mineral alteration. All planned analyses have been completed, as shown on Table 3-2.

\subsection{Geophysical Data}

Geophysical logs were run to further characterize the lithology, structure, and water content of the rocks encountered. In addition, logs were run to evaluate borehole conditions, to determine the fluid levels during the course of drilling, and to monitor completion progress. Geophysical logging was conducted during three stages of drilling and completion: prior to setting surface casing, prior to installing the completion casing, and during stemming of the well (annulus investigation log). Some logs were run in both the saturated and unsaturated zones of the borehole, while others (e.g., thermal flow $\log$, chemistry log, ultrasonic borehole imager log, etc.) were run only in the saturated interval. A complete listing of the logs, dates run, depths, and service company is provided in Table 3-3. Preliminary geophysical data from the logs are reproduced in Appendix D.

A delay of over 13 hours during the second stage of logging was caused by a bridge in the hole (see Section 2.3). Several attempts were made to run the logging tools past the obstruction or knock it loose, but eventually it was necessary to pull out the logging tools and run the 121/4-in. bit into the hole to push the material down hole. Schlumberger was then rigged up again and logging continued. Over 11 hours of time was also lost due to the need to repair and/or replace several faulty Schlumberger logging tools. Overall, the quality of the geophysical data collected, however, was acceptable. 
Table 3-1

Sidewall Core Samples from Well ER-EC-5

\begin{tabular}{|c|c|c|}
\hline $\begin{array}{l}\text { Core Depth } \\
\text { meters (feet) }\end{array}$ & $\begin{array}{c}\text { Length } \\
\text { Recovered } \\
\text { cm (in.) }\end{array}$ & $\begin{array}{c}\text { Stratigraphic } \\
\text { Unit }^{b}\end{array}$ \\
\hline $349.6(1,147)$ & $2.29(0.9)$ & \multirow{15}{*}{ Tmar } \\
\hline $365.8(1,200)$ & $4.06(1.6)$ & \\
\hline $373.4(1,225)$ & $3.56(1.4)$ & \\
\hline $376.4(1,235)$ & $3.56(1.4)$ & \\
\hline $388.6(1,275)$ & 4.57 (1.8) & \\
\hline $438.9(1,440)$ & 4.06 (1.6) & \\
\hline $472.4(1,550)$ & $3.81(1.5)$ & \\
\hline $528.8(1,735)$ & 3.81 (1.5) & \\
\hline $565.7(1,856)$ & 4.06 (1.6) & \\
\hline $580.0(1,903)$ & 3.81 (1.5) & \\
\hline $605.3(1,986)$ & $2.79(1.1)$ & \\
\hline $624.8(2,050)$ & $3.56(1.4)$ & \\
\hline $641.6(2,105)$ & 3.81 (1.5) & \\
\hline $648.3(2,127)$ & 3.05 (1.2) & \\
\hline $656.2(2,153)$ & $4.83(1.9)$ & \\
\hline $711.4(2,334)$ & $2.29(0.9)$ & \multirow{3}{*}{ Tmap } \\
\hline $736.1(2,415)$ & 3.81 (1.5) & \\
\hline $745.2(2,445)$ & $4.32(1.7)$ & \\
\hline
\end{tabular}

a All samples obtained using a rotary mechanical sidewall coring tool operated by Schlumberger.

b Tmar =mafic-rich Ammonia Tanks Tuff; Tmap =mafic-poor Ammonia Tanks Tuff. See Appendix C for more information on the stratigraphy and lithology of Well ER-EC-5. 
Table 3-2

Status of Rock Sample Analyses for Well ER-EC-5

\begin{tabular}{|c|c|c|c|c|c|}
\hline \multirow{3}{*}{$\begin{array}{c}\text { Depth }^{\mathbf{a}} \\
\text { meters (feet) }\end{array}$} & \multirow{3}{*}{$\begin{array}{l}\text { Sample } \\
\text { Type }^{\text {b }}\end{array}$} & \multicolumn{4}{|c|}{ Analyses Performed $^{c}$} \\
\hline & & \multirow{2}{*}{$\begin{array}{c}\text { Petrographic } \\
\text { PTS } \\
\end{array}$} & \multirow{2}{*}{$\begin{array}{c}\text { Mineralogic } \\
\text { XRD } \\
\end{array}$} & \multicolumn{2}{|c|}{ Chemical } \\
\hline & & & & XRF & $\mathrm{Fe}^{2+} / \mathrm{Fe}^{3+}$ \\
\hline $39.6(130)$ & DP & C & C & C & C \\
\hline $70.1(230)$ & DA & C & C & C & C \\
\hline $76.2(250)$ & DA & $\mathrm{C}$ & $\mathrm{C}$ & C & $\mathrm{C}$ \\
\hline $88.4(290)$ & DA & C & C & C & C \\
\hline $118.9(390)$ & DA & C & C & C & C \\
\hline $131.1(430)$ & DA & C & C & C & C \\
\hline $167.6(550)$ & DA & C & C & C & C \\
\hline $240.8(790)$ & DA & C & C & C & C \\
\hline $253.0(830)$ & DA & C & C & C & C \\
\hline $271.3(890)$ & DA & C & C & C & C \\
\hline 280.4 (920) & DA & C & C & C & C \\
\hline $298.7(980)$ & DA & C & C & C & C \\
\hline $320.0(1,050)$ & DA & C & C & C & C \\
\hline $347.5(1,140)$ & DA & C & C & C & C \\
\hline $408.4(1,340)$ & DA & C & C & C & C \\
\hline $463.3(1,520)$ & DA & C & C & C & C \\
\hline $530.4(1,740)$ & DA & C & C & C & C \\
\hline $582.2(1,910)$ & DA & C & C & C & C \\
\hline $652.3(2,140)$ & DA & C & C & C & C \\
\hline $685.8(2,250)$ & DA & C & C & C & C \\
\hline $698.0(2,290)$ & DA & C & C & C & C \\
\hline $743.7(2,440)$ & DA & C & C & C & C \\
\hline $762.0(2,500)$ & DA & C & C & C & C \\
\hline
\end{tabular}

a Depth represents base of 3.0-m (10-ft) sample interval.

b $\quad \mathbf{D A}=$ drill cuttings that represent lithologic character of interval; $\mathbf{D P}=$ pumice fragment.

c $\quad \mathbf{C}=$ analysis complete. Analysis type: $\mathbf{P T S}=$ polished thin section; $\mathbf{X R D}=\mathrm{x}$-ray diffraction; $\mathbf{X R F}=\mathbf{X}$-ray fluorescence; $\mathrm{Fe}^{2+} / \mathrm{Fe}^{3+}=$ wet chemical analysis for iron. 
Table 3-3

Well ER-EC-5 Geophysical Log Summary

(Page 1 of 2)

\begin{tabular}{|c|c|c|c|c|c|c|}
\hline Geophysical Log Type $^{\text {a }}$ & Log Purpose & $\begin{array}{l}\text { Logging } \\
\text { Service }\end{array}$ & $\begin{array}{l}\text { Date } \\
\text { Logged }\end{array}$ & Run Number & $\begin{array}{l}\text { Bottom of } \\
\text { Logged } \\
\text { Interval }^{b} \\
\text { meters (feet) }\end{array}$ & $\begin{array}{l}\text { Top of Logged } \\
\text { Interval } \\
\text { meters (feet) }\end{array}$ \\
\hline * Natural Gamma Ray Spectroscopy & $\begin{array}{l}\text { Stratigraphic correlation, } \\
\text { mineralogy, natural and man- } \\
\text { made radiation }\end{array}$ & Schlumberger & $\begin{array}{l}6 / 28 / 1999 \\
7 / 6 / 1999\end{array}$ & $\begin{array}{l}\text { SGR-1 } \\
\text { SGR-2 }\end{array}$ & $\begin{array}{l}329.8(1,082) \\
752.6(2,469)\end{array}$ & $\begin{array}{c}21.3(70) \\
310.9(1,020)\end{array}$ \\
\hline * Gamma Ray/Four Arm Caliper & $\begin{array}{l}\text { Stratigraphic correlation/borehole } \\
\text { conditions, cement volume } \\
\text { calculation }\end{array}$ & Schlumberger & $\begin{array}{l}6 / 28 / 1999 \\
7 / 5 / 1999\end{array}$ & $\begin{array}{l}\text { SGR-1/CA4-1 } \\
\text { GR-2/CA4-2 }\end{array}$ & $\begin{array}{l}344.4(1,130) \\
761.7(2,499)\end{array}$ & $\begin{array}{c}21.3(70) \\
342.6(1,124)\end{array}$ \\
\hline $\begin{array}{l}\text { * Epithermal Neutron/Density/ } \\
\text { Gamma Ray/ Caliper }\end{array}$ & $\begin{array}{l}\text { Total water content/borehole } \\
\text { conditions }\end{array}$ & Schlumberger & $\begin{array}{l}6 / 28 / 1999 \\
7 / 5 / 1999\end{array}$ & $\begin{array}{l}\text { ENP-1/CDL-1/ } \\
\text { GR-1/CAL-1 } \\
\text { ENP-2/CDL-2/ } \\
\text { GR-3/CAL-2 }\end{array}$ & $\begin{array}{l}338.3(1,110) \\
761.4(2,498)\end{array}$ & $\begin{array}{c}21.3(70) \\
173.1(568)\end{array}$ \\
\hline $\begin{array}{l}\text { *Array Induction } \\
\text { Log/Caliper/Gamma Ray }\end{array}$ & $\begin{array}{l}\text { Rock porosity, lithologic } \\
\text { determination/stratigraphic } \\
\text { correlation/borehole conditions }\end{array}$ & Schlumberger & $6 / 28 / 1999$ & IND-1/GR-1/CAL-1 & $340.2(1,116)$ & $21.3(70)$ \\
\hline Oriented Color Video & $\begin{array}{l}\text { Lithologic characterization, } \\
\text { fracture and void analysis/ } \\
\text { stratigraphic correlation/ hole } \\
\text { conditions }\end{array}$ & $\begin{array}{l}\text { Barbour Well } \\
\text { Surveying }\end{array}$ & $6 / 29 / 1999$ & 1 & $332.2(1,090)$ & Ground Level \\
\hline * Dual Laterolog/Gamma Ray & $\begin{array}{l}\text { Saturated zone: water } \\
\text { saturation/ stratigraphic } \\
\text { correlation }\end{array}$ & Schlumberger & $7 / 5 / 1999$ & GR-4/DLL-1 & $757.4(2,485)$ & $342.6(1,124)$ \\
\hline $\begin{array}{l}\text { Ultrasonic Borehole Imager/ } \\
\text { Gamma Ray }\end{array}$ & $\begin{array}{l}\text { Saturated zone: lithologic } \\
\text { characterization, fracture and } \\
\text { void analysis/stratigraphic } \\
\text { correlation }\end{array}$ & Schlumberger & 7/6/1999 & BHTV-1/ SGR-2 & $752.6(2,469)$ & $556.0(1,824)$ \\
\hline Micro-resistivity Electronic scanner & $\begin{array}{l}\text { Saturated zone: lithologic } \\
\text { characterization/fracture and } \\
\text { void analysis/stratigraphic } \\
\text { correlation }\end{array}$ & Schlumberger & 7/7/1999 & FMS-1 & $576.1(1,890)$ & $342.6(1,124)$ \\
\hline Temperature/Gamma Ray & $\begin{array}{l}\text { Saturated zone: groundwater } \\
\text { temperature/ stratigraphic } \\
\text { correlation }\end{array}$ & Schlumberger & $7 / 5 / 1999$ & TL-1/GR-2 & $761.7(2,499)$ & 0 \\
\hline
\end{tabular}


Table 3-3

Well ER-EC-5 Geophysical Log Summary

(Page 2 of 2)

\begin{tabular}{|c|c|c|c|c|c|c|}
\hline Geophysical Log Type ${ }^{a}$ & Log Purpose & $\begin{array}{l}\text { Logging } \\
\text { Service }\end{array}$ & $\begin{array}{l}\text { Date } \\
\text { Logged }\end{array}$ & Run Number & $\begin{array}{l}\text { Bottom of } \\
\text { Logged } \\
\text { Interval }^{b} \\
\text { meters (feet) }\end{array}$ & $\begin{array}{l}\text { Top of Logged } \\
\text { Interval } \\
\text { meters (feet) }\end{array}$ \\
\hline $\begin{array}{l}\text { Gamma Ray/Digital Array Sonic } \\
\text { A. Wave-form and variable density } \\
\text { presentations } \\
\text { * B. Sonic porosity and travel time } \\
\text { (STC) computations }\end{array}$ & $\begin{array}{l}\text { Saturated zone: } \\
\text { A. Porosity, lithologic } \\
\text { determination } \\
\text { B. Fracture identification }\end{array}$ & Schlumberger & 7/7/1999 & GR-5/AC-1 & $\begin{array}{l}753.8(2,473) \\
753.8(2,473)\end{array}$ & $\begin{array}{l}304.8(1,000) \\
304.8(1,000)\end{array}$ \\
\hline Mechanical Sidewall Coring Tool & Geologic samples & Schlumberger & 7/7/1999 & MSCT-1 & $745.2(2,445)$ & $349.6(1,147)$ \\
\hline * Thermal Flow Log & $\begin{array}{l}\text { Rate and direction of } \\
\text { groundwater flow in borehole }\end{array}$ & $\begin{array}{l}\text { Desert } \\
\text { Research } \\
\text { Institute }\end{array}$ & $7 / 7 / 1999$ & 1 & $755.9(2,480)$ & $310.6(1,019)$ \\
\hline * Chemistry Log & $\begin{array}{l}\text { Groundwater chemistry, } \\
\text { formation transmissivity }\end{array}$ & $\begin{array}{l}\text { Desert } \\
\text { Research } \\
\text { Institute }\end{array}$ & $7 / 7 / 1999$ & 1 & $755.9(2,480)$ & $310.6(1,019)$ \\
\hline Nuclear Annulus Investigation Log & Well construction monitoring & Colog & 7/9-10/1999 & 1 & $746.2(2,448)$ & $121.9(400)$ \\
\hline Gyroscopic Survey & Borehole deviation & Gyrodata & 10/19/1999 & 1 & $737.3(2,419)$ & $7.6(25)$ \\
\hline
\end{tabular}

a Logs presented in geophysical log summary, Appendix D, are indicated by *.

b Depth below ground surface.

c Logging interval recorded on print of log. Discrete measurements were made at seven locations between the depths of 387.1 and $749.2 \mathrm{~m}(1,270$ and $2,458 \mathrm{ft})$. 


\subsection{Geology and Hydrogeology}

This section describes the geology and hydrogeology of Well ER-EC-5. The basis for the discussions in Section 4.0 is the detailed lithologic log presented in Appendix C. The detailed lithologic log was developed using drill cuttings and sidewall core samples, geophysical logs, drilling parameters, and nearby geologic exposures (Wahl et al., 1997). Interpretations by R. G. Warren of LANL (Warren 2003; Warren et al., 2003) of petrographic, mineralogic, and chemical analyses of selected lithologic samples from the well were evaluated and where appropriate, incorporated into the lithologic log.

Interpretations of data from this well have been incorporated into the hydrostratigraphic model for the Pahute Mesa - Oasis Valley area (BN, 2002).

\subsection{Geology}

Well ER-EC-5 is located approximately $9.2 \mathrm{~km}(5.7 \mathrm{mi})$ west of the north peak of Timber Mountain, within the moat of the Timber Mountain caldera complex (TMCC) (Figure 4-1). The TMCC is composed of at least two nested calderas, the Rainier Mesa caldera and the younger Ammonia Tanks caldera. The formation of these calderas is the result of the eruption of the Rainier Mesa Tuff (erupted 11.6 million years ago [Ma] [Sawyer et al., 1994]) and the Ammonia Tanks Tuff (erupted 11.45 Ma [Sawyer, et al., 1994]), and both tuffs are considered part of the Timber Mountain Group. Following the collapse of the Ammonia Tanks caldera, resurgence of a central dome created the present topographic expression of the TMCC, including Timber Mountain and the surrounding "moat" (Figure 4-1). Younger volcanic rocks partially filled the moat, burying most of the Timber Mountain Group rocks within the moat. Moat-filling units exposed at the surface near Well ER-EC-5

(Figure 4-2; see also Lipman et al., 1966) consist mainly of tuff and lava of the Volcanics of Fortymile Canyon, erupted from various vents near the TMCC shortly after collapse of the Ammonia Tanks caldera, and younger ash-flow tuffs assigned to the Thirsty Canyon Group, erupted approximately 9.4 Ma (Sawyer et al., 1994) from the Black Mountain caldera located about 23 km (14 mi) northnorthwest of the well (Figure 4-1).

The mapped surface geology in the vicinity of Well ER-EC-5 indicates that drilling started in the Pahute Mesa Tuff of the Thirsty Canyon Group (Figure 4-2). Rocks of the Thirsty Canyon Group are characterized by their general peralkaline mineralogy and lack of quartz phenocrysts (Wahl et al., 1997). So, based on the presence of clinopyroxene and olivine and lack of biotite (characteristics of 
This page intentionally left blank. 


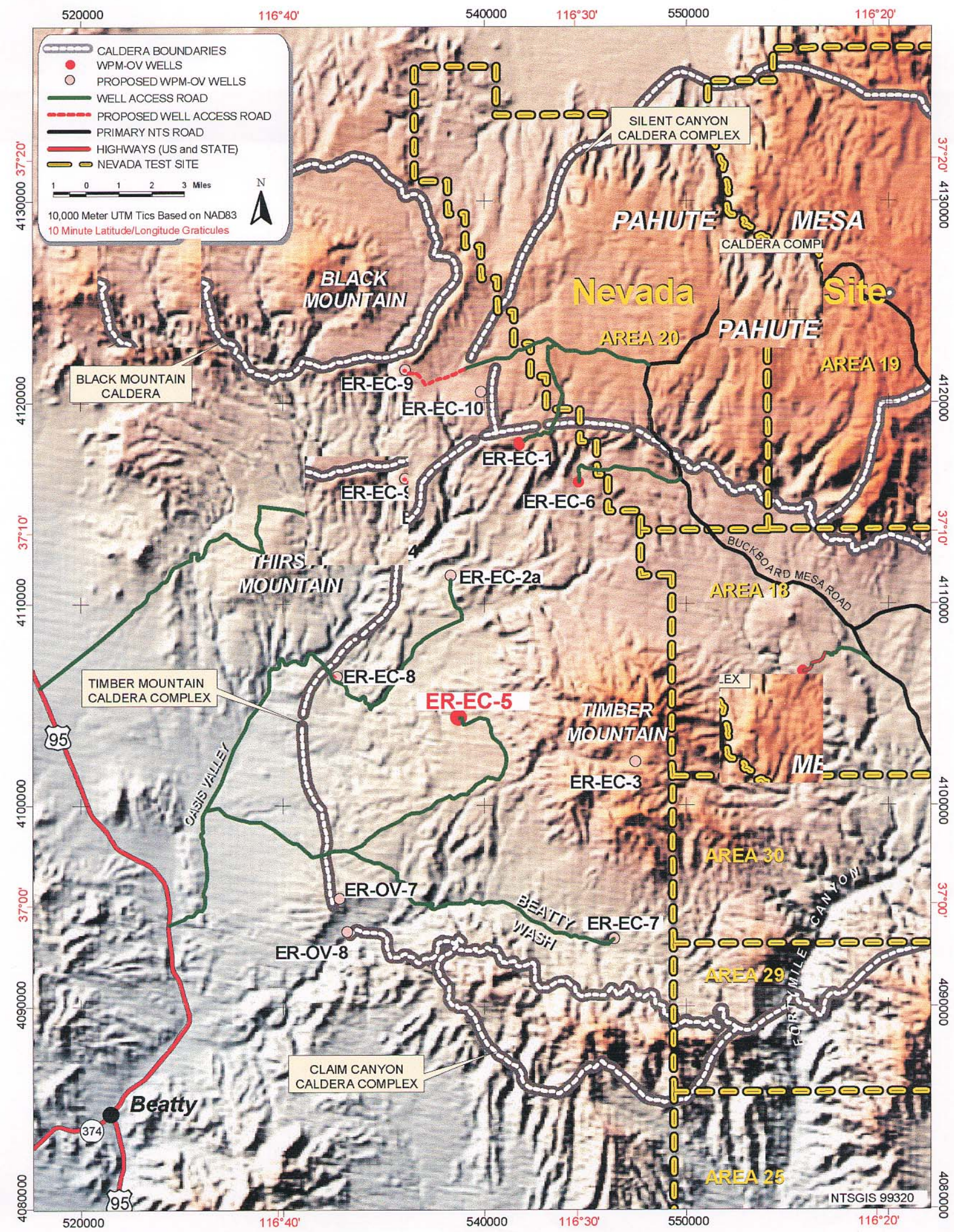

Figure 4-1

Map of Western Pahute Mesa - Oasis Valley Area Showing Theorized Locations of Caldera Boundaries (after Wahl et al., 1997) 
This page intentionally left blank. 


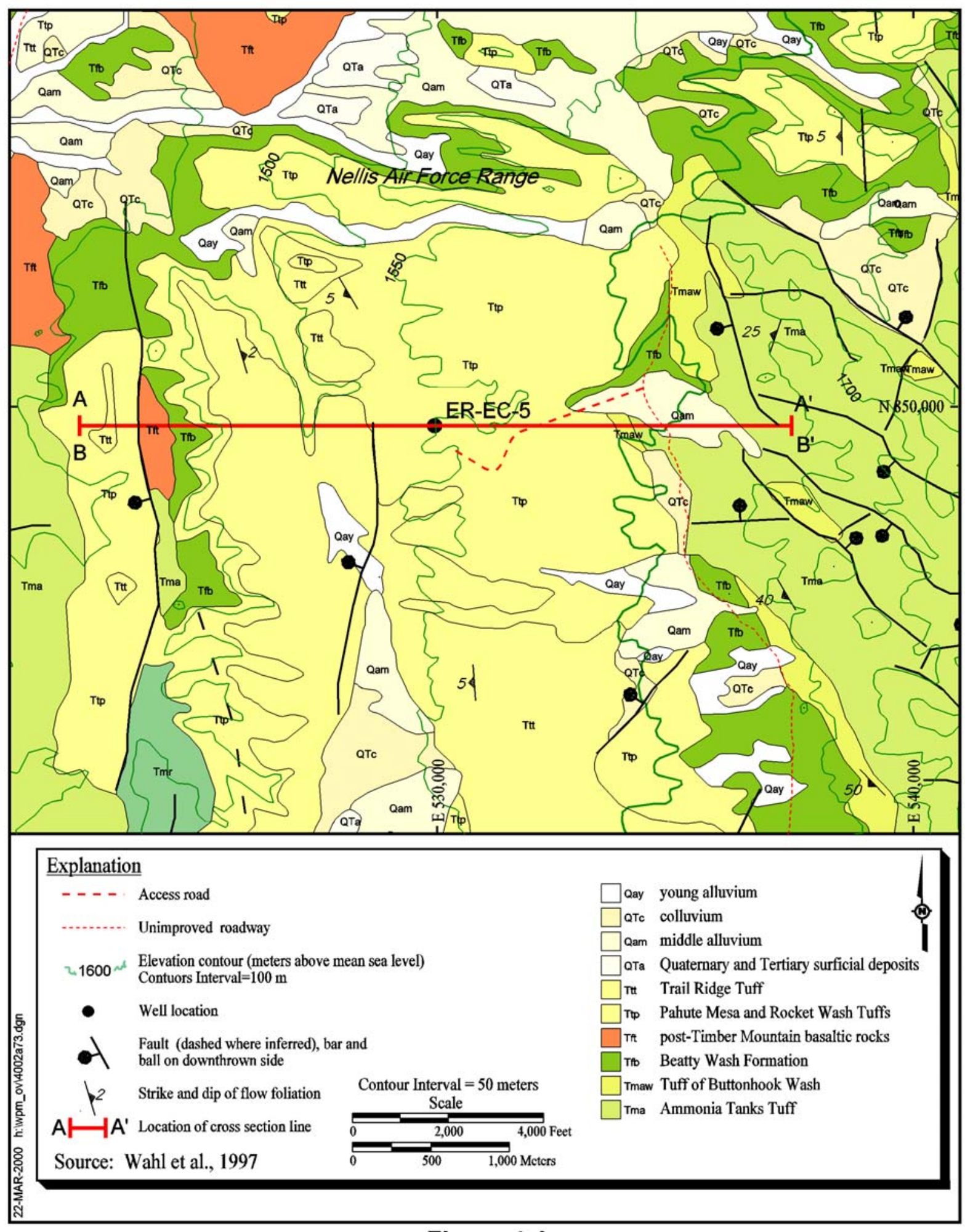

Figure 4-2

Geologic Map of the Well ER-EC-5 Site 
This page intentionally left blank. 


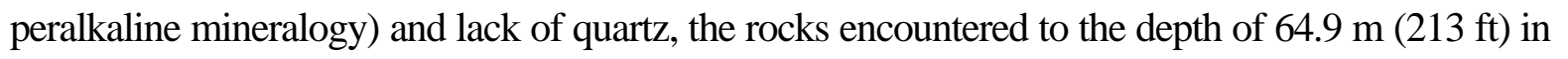
Well ER-EC-5 are assigned to the Thirsty Canyon Group. Below the partially to moderately welded Pahute Mesa ash-flow tuff, a thin, vitric, pumice-rich, nonwelded tuff was logged at the depth of 32.3 to $37.5 \mathrm{~m}$ (106 to $123 \mathrm{ft}$ ). This bed is interpreted to be a tephra, or pumice-fall, erupted as a precursor to the overlying Pahute Mesa Tuff. Based on this interpretation, the nonwelded ash-flow tuff below the depth of $37.5 \mathrm{~m}$ (123 ft) is assigned to the Rocket Wash Tuff of the Thirsty Canyon Group.

After penetrating $27.4 \mathrm{~m}$ (90 ft) of Rocket Wash Tuff, Well ER-EC-5 penetrated $56.4 \mathrm{~m}$ (185 ft) of mostly reworked tuff characterized by sand-size material in a finer grained zeolitic and weakly to moderately calcareous matrix. Sand-size material consists of pumice fragments, biotite flakes, sphene, hornblende, frosted feldspar and quartz grains, and subangular to subrounded lithic fragments of various tuffaceous volcanic rocks. Based on the location of Well ER-EC-5 within the moat of the TMCC and the stratigraphic position of this reworked tuff beneath the Thirsty Canyon Group, this interval is interpreted to be Miocene in age and therefore assigned to the Tertiary caldera moat-filling sedimentary deposits ("Tgc" in Wahl et al., 1997). Similar beds were encountered in the same stratigraphic position in wells ER-18-2 (DOE, 2003), UE-18r (Carr et al., 1968), and UE-18t (Byers and Hawkins, 1981), all drilled within the moat of the TMCC.

Beneath the moat-filling deposits, Well ER-EC-5 penetrated $125.6 \mathrm{~m} \mathrm{(412} \mathrm{ft)} \mathrm{of} \mathrm{nonwelded} \mathrm{tuff}$ assigned to the rhyolite of Beatty Wash (Figure 4-3), a subunit of the Beatty Wash Formation of the Volcanics of Fortymile Canyon. The assignment of this interval to the rhyolite of Beatty Wash is based on the presence of minor to common biotite and pseudomorphs after sphene, and the absence of quartz phenocrysts. Three distinct intervals of pumice-rich nonwelded tuff were identified, each separated by a thin (less than $6.1 \mathrm{~m}$ [20 ft] thick) reddish-brown bed. The reddish-brown beds are clearly indicated on geophysical logs by an increase in density and gamma ray radiation, and abrupt changes in electrical resistivity.

An interval of landslide breccia, tuffaceous gravels, and bedded and reworked tuffs $75.0 \mathrm{~m}$ (246 ft) thick was logged between the rhyolite of Beatty Wash and the Ammonia Tanks Tuff (Figure 4-3). These rocks are interpreted to be coarse alluvial and landslide debris shed from Timber Mountain during resurgence. From 246.9 to $268.2 \mathrm{~m}$ (810 to $880 \mathrm{ft}$ ), Well ER-EC-5 penetrated two intervals of landslide breccia separated by an interval of tuffaceous gravel. The cuttings samples for these intervals are dominated by angular (landslide breccia) to subangular and subrounded (tuffaceous gravel) clasts of biotite-poor, densely welded ash-flow tuff with a very sparse, coarse-grained, granular, 
This page intentionally left blank. 

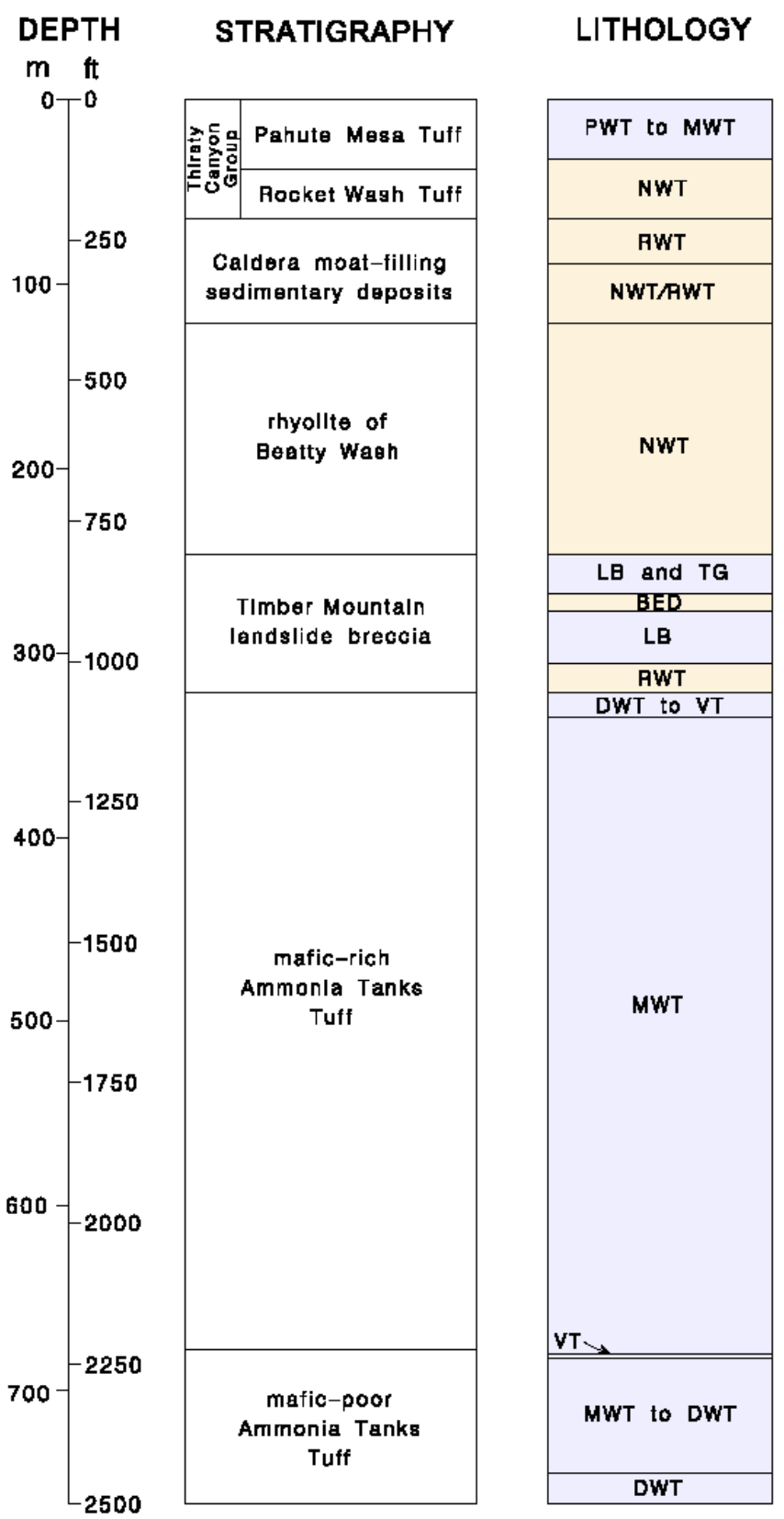

ALTERATION

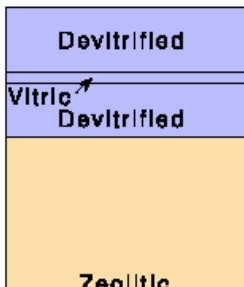

Zeolltle, lesser silicic and argillic

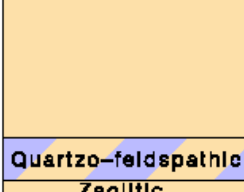
Zoolltle

Quartzo-feldspathlo Zeolltic, leserer argillic Devitrlfled

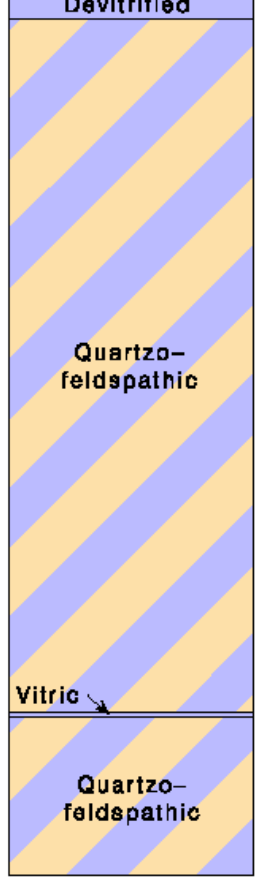

HYDROGEOLOGY

showing locations of

gravel-packed Intervale
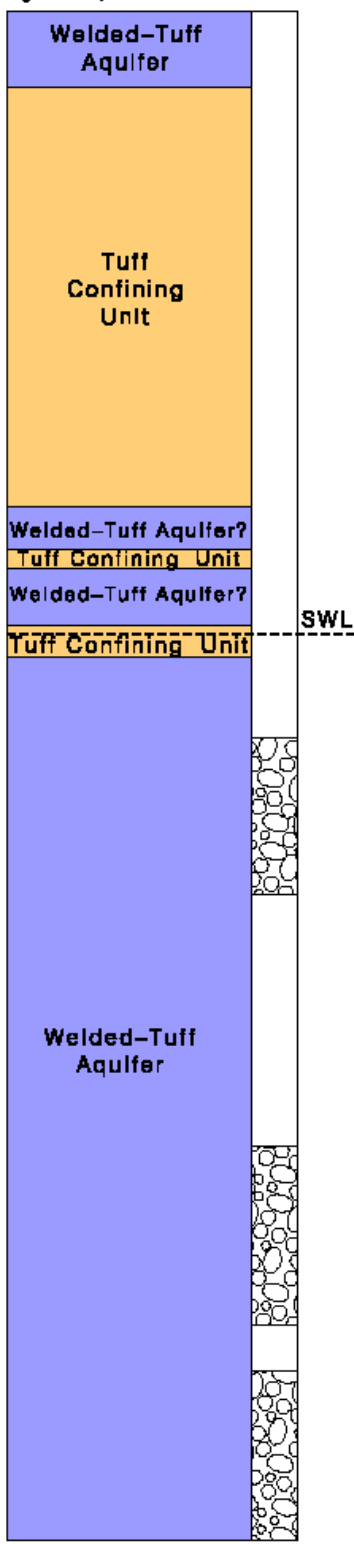

NOTE: See Appendix C for detalled Ilthologle descrlptions

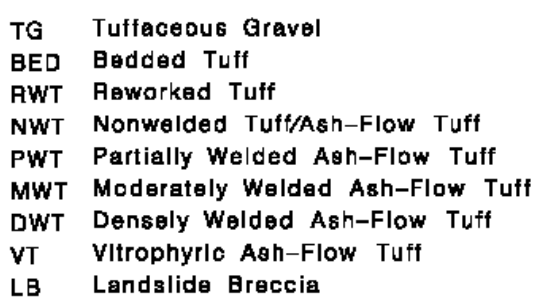

Walded Ash-flow Tuff and Landslide Breccle

Teworked, Bedded, and

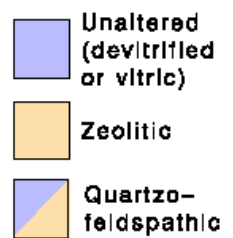

feldspathla

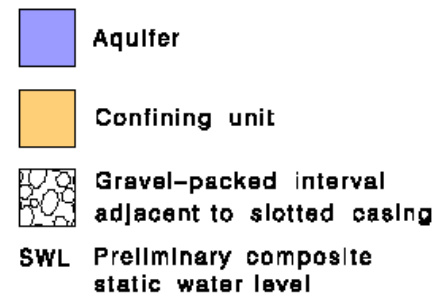

Figure 4-3

Geology and Hydrogeology of Well ER-EC-5 
This page intentionally left blank. 
tuffaceous matrix present on some of the fragments. Another landslide breccia with similar composition is present from 277.4 to $305.4 \mathrm{~m}$ (910 to $1,002 \mathrm{ft}$ ), separated from the upper landslide breccia by

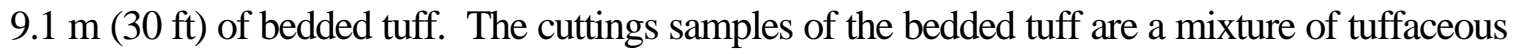
lithologies consisting mostly of nonwelded and reworked tuff containing common zeolitic pumice fragments, quartz and feldspar phenocrysts, and biotite. Between the lowermost landslide breccia and the top of the Ammonia Tanks Tuff, from 305.4 to 321.9 m (1,002 to 1,056 ft), Well ER-EC-5 penetrated a very lithic-rich reworked tuff consisting of very abundant subangular to subrounded fragments of mafic-poor, densely welded tuff in a zeolitic, argillic, and moderately calcareous matrix.

The entire interval from 246.9 to $321.9 \mathrm{~m}$ (810 to 1,056 ft) described above, is given the stratigraphic assignment of Timber Mountain landslide breccia (Tmx) after Wahl et al. (1997) (Figure 4-3). As described by Wahl et al. (1997), this unit includes breccia emplaced as debris flows shed from the caldera walls during and after collapse of the Rainier Mesa and Ammonia Tanks calderas. A landslide breccia resulting from caldera collapse typically contains clasts of the older volcanic rocks that made up the caldera wall, such as the Paintbrush Group. However, the clasts in the breccia penetrated by Well ER-EC-5 all appear to be Ammonia Tanks-related (i.e., Tuff of Buttonhook Wash or Ammonia Tanks Tuff) based on the presence of biotite, trace sphene, and a significant abundance of quartz phenocrysts. The lack of clasts of older volcanic rocks implies that the clasts were not shed from a caldera wall, but rather were eroded from Timber Mountain during resurgence and uplift after the collapse of the Ammonia Tanks caldera.

Directly beneath the landslide breccia, Well ER-EC-5 penetrated $356.3 \mathrm{~m}(1,169 \mathrm{ft})$ of moderately welded to vitrophyric ash-flow tuff belonging to mafic-rich Ammonia Tanks Tuff; the well reached TD at $762.0 \mathrm{~m}(2,500 \mathrm{ft})$ within densely welded ash-flow tuff of the mafic-poor Ammonia Tanks Tuff (Figure 4-3). A total thickness of $440.1 \mathrm{~m}$ (1,444 ft) of welded Ammonia Tanks Tuff was penetrated by Well ER-EC-5, recognized by abundant felsic phenocrysts including feldspar and quartz, the presence of clinopyroxene, and a conspicuous increase in biotite content from the Beatty Wash Formation above. The transition from mafic-rich to mafic-poor Ammonia Tanks Tuff at $678.2 \mathrm{~m}$ $(2,225 \mathrm{ft})$ is represented by a decrease in biotite content and a conspicuous increase in thorium and decrease in potassium on the natural spectral gamma ray log. Two intervals of vitrophyric ash-flow tuff were identified, one near the top of the mafic-rich Ammonia Tanks Tuff, and the other near the top of the mafic-poor section (Figure 4-3).

Although Well ER-EC-5 did not penetrate a complete section of Ammonia Tanks Tuff, stratigraphic information from the well strongly suggests that the well is located within the Ammonia Tanks caldera. 
Ammonia Tanks Tuff within the Ammonia Tanks caldera is at least $762 \mathrm{~m}(2,500 \mathrm{ft})$ thick (see stratigraphic data for UE-18r in Warren et al. [2003]). At Well ER-EC-5, $440.1 \mathrm{~m}(1,444 \mathrm{ft})$ of Ammonia Tanks Tuff was penetrated before the hole reached TD just $83.8 \mathrm{~m}(275 \mathrm{ft})$ into the maficpoor Ammonia Tanks Tuff, the lower subunit of the formation. In addition, the top of the mafic-rich Ammonia Tanks Tuff in Well ER-EC-5 is strongly welded, indicating that the less welded upper portion is missing, having probably been eroded off as a result of caldera resurgence. This suggests that Well ER-EC-5 is located within the Ammonia Tanks caldera, and that the caldera margin must be west of the well. This is consistent with previous interpretations (Wahl et al., 1997; Grauch et al., 1997; and Warren et al., 2000) that place the Ammonia Tanks caldera margin west of Well ER-EC-5 along the east side of the Transvaal Hills.

Alteration has a significant effect on both the general hydraulic character of volcanic rocks and on how radionuclides migrate through these rocks. The predominant type of mineralogic alteration observed in each stratigraphic unit encountered in Well ER-EC-5 is illustrated on Figure 4-3. Above the depth of

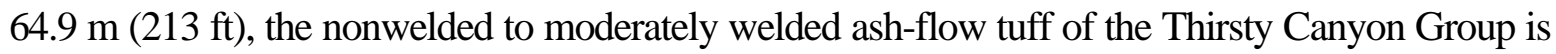
mostly devitrified. Below $64.9 \mathrm{~m}$ (213 ft), to the base of the rhyolite of Beatty Wash at $246.9 \mathrm{~m}$ $(810 \mathrm{ft})$, reworked and nonwelded tuffs are predominantly zeolitic, with lesser silicic and argillic alteration also present. Drill cuttings samples from the landslide breccia and the tuffaceous gravel intervals between the rhyolite of Beatty Wash and the Ammonia Tanks Tuff are mostly a concentrate of quartzo-feldspathic, densely welded tuff fragments with very little tuffaceous matrix visible. The lateral extent of these lithic-rich zones is unknown, however they are likely emplaced within an overall zeolitic matrix, as indicated by the interbedded zeolitic bedded and reworked tuffs within this interval. Underlying the Timber Mountain landslide breccia, to the bottom of the hole, rocks show higher temperature quartzo-feldspathic alteration except for the two thin intervals of vitrophyre from 321.9 to $335.0 \mathrm{~m}$ (1,056 to $1,099 \mathrm{ft})$ and from 680.6 to $682.8 \mathrm{~m}$ (2,233 to 2,240 ft), which are vitric to partially devitrified.

\subsection{Predicted Versus Actual Geology}

The predicted geology for Well ER-EC-5 (IT, 1998) was based on surface exposures (Wahl et al., 1997; Figure 4-2) and the locations of caldera margins as interpreted by Warren (1994). A comparison of the predicted and the actual stratigraphy is provided in Figure 4-5. Located within the Southwestern Timber Mountain Moat structural block, a structural block characterized by thick intracaldera Ammonia Tanks and Rainier Mesa tuffs (Warren, 1994; Warren et al., 2000), the well was 

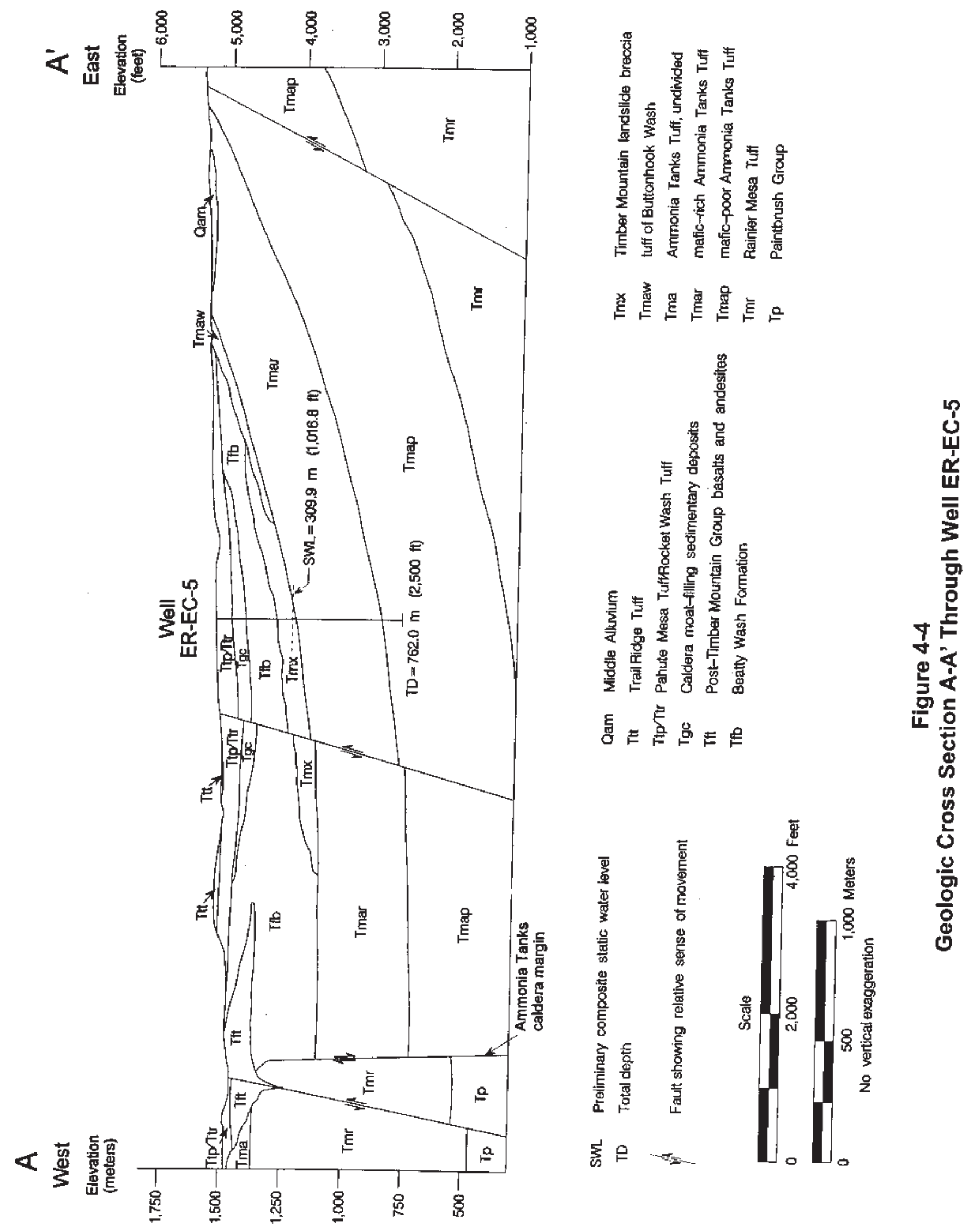
predicted to reach TD within the Ammonia Tanks Tuff after penetrating approximately $609.6 \mathrm{~m}$ (2,000 ft) of Ammonia Tanks Tuff welded ash-flow tuff. Due mainly to the presence of a 56.4-m (185-ft) thick interval of Tertiary caldera moat-filling sediments and $75.0 \mathrm{~m}$ (246 ft) of Timber Mountain landslide breccia, the top of the Ammonia Tanks Tuff was penetrated almost $200 \mathrm{~m}$ (655 ft) deeper than expected. As a result, only $440.1 \mathrm{~m}$ (1,444 ft) of Ammonia Tanks Tuff was actually drilled in Well ER-EC-5 at the planned TD of $762.0 \mathrm{~m}(2,500 \mathrm{ft})$. As discussed above, it is likely the well has penetrated only the upper portion of a very thick intra-caldera sequence of Ammonia Tanks Tuff, placing Well ER-EC-5 within the Ammonia Tanks caldera (Figure 4-4), consistent with pre-drilling interpretations.

Although Tertiary caldera moat-filling sediments were not predicted to occur in Well ER-EC-5, their presence is not surprising because these sediments are exposed extensively at the surface within the moat of the TMCC. Moat-filling sediments are also present in the same stratigraphic position in wells ER-18-2, UE-18r, and UE-18t, all located within the moat.

Also not predicted was the interval of landslide breccia directly overlying the Ammonia Tanks Tuff. No similar interval has been recognized above the Ammonia Tanks Tuff in other holes drilled within the moat; however, the presence of this unit in Well ER-EC-5 is not surprising due to its proximity to the rising Timber Mountain dome.

\subsection{Hydrogeology}

As predicted (IT, 1998), the only saturated aquifer encountered in Well ER-EC-5 consists of the moderately welded to vitrophyric ash-flow tuffs of the Ammonia Tanks Tuff (Figure 4-3). This welded-tuff aquifer is at least $440.1 \mathrm{~m}(1,444 \mathrm{ft})$ thick in the Well ER-EC-5 vicinity. Although the welded ash-flow tuffs are dense and have very low primary permeability, they are expected to support a well-interconnected fracture system through which groundwater can flow. Lithologic observations and data from geophysical logs suggest that fracture zones may be present in the welded tuff near the depths of 503 and $594 \mathrm{~m}$ (1,650 and 1,950 ft), two intervals where increases in water production were noted during drilling.

The characterization of unsaturated units is important because they may be saturated in other portions of the model area, and thus may affect groundwater flow elsewhere. Rocks in the unsaturated zone of Well ER-EC-5 have hydrologic properties of either welded-tuff aquifer or tuff confining unit (Figure 4-3). The partially to moderately welded ash-flow tuffs of the Pahute Mesa Tuff are 


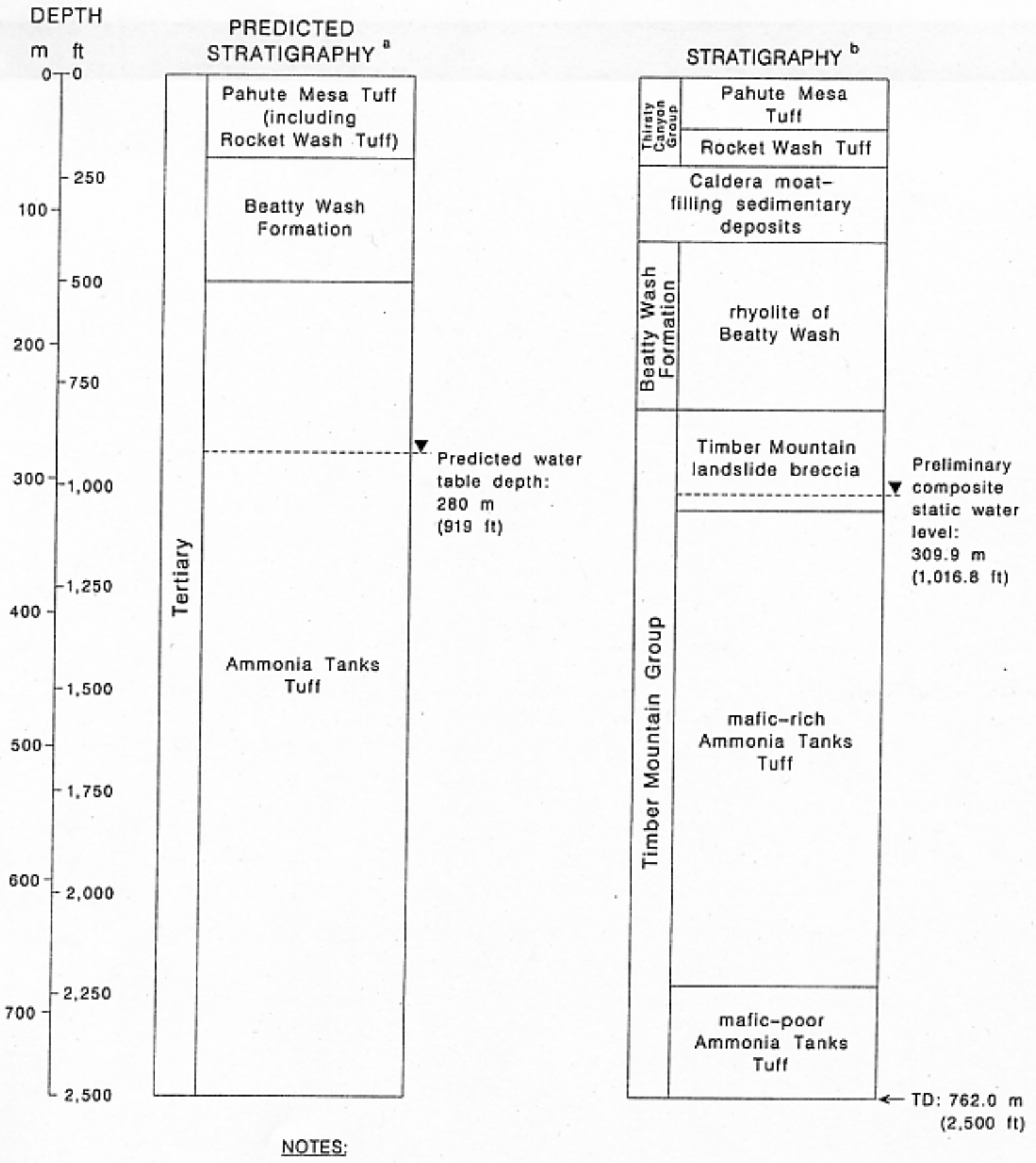

a IT, 1998

b See Appendix C for detailed

Surface Elevation (pad): $1,547.5 \mathrm{~m}(5,077.0 \mathrm{ft})$ lithologic descriptions.

Nevada Coordinates (NAD 1983): $N$ 20,534,763.8 ft; E 1,669.938.7 ft Completed: 7/11999

Figure 4-5

Predicted and Actual Stratigraphy at Well ER-EC-5 
grouped as a welded-tuff aquifer. However, most of this interval is partially welded ash-flow tuff which may be less supportive of fractures, and thus have a lower transmissivity than an aquifer made up of higher density tuffs. Underlying this welded-tuff aquifer is a thick tuff confining unit made up mostly of zeolitic nonwelded and reworked tuffs of the rhyolite of Beatty Wash and Tertiary caldera moat-filling sedimentary deposits. The devitrified, nonwelded tuff of the overlying Rocket Wash Tuff is also included with the tuff confining unit because it is not expected to bear open fractures.

Separating this tuff confining unit from the welded-tuff aquifer of the Ammonia Tanks Tuff is an interval consisting of landslide breccia, tuffaceous gravel, and bedded and reworked tuff. The bedded and reworked tuffs are zeolitic, forming two thin $(9.1 \mathrm{~m}$ [30 ft] and $16.5 \mathrm{~m}$ [54 ft] thick) tuff confining units. The cuttings samples of the landslide breccia and tuffaceous gravels consist mostly of pieces of densely welded ash-flow tuff with very little matrix apparent. Therefore, in the immediate vicinity of Well EREC-5, these rocks will likely have hydrologic properties equivalent to a welded-tuff aquifer. However, the well may have been drilled into a very lithic-rich lens of an otherwise more matrix-supported zeolitic bedded tuff, or into a single very large boulder emplaced within a zeolitic matrix, and the overall properties may be more similar to those of a tuff confining unit.

Figure 4-6 is a hydrogeologic cross section through the Well ER-EC-5 vicinity, illustrating the complexities associated with predicting the lateral continuity of hydraulic properties of volcanic rocks in caldera settings. See the discussion of general hydraulic properties of expected WPM-OV units in IT (1998), Section E.6.2 and Table E.6-1. Proposed hydrologic testing in the WPM-OV wells will verify the actual hydraulic character of these units. 


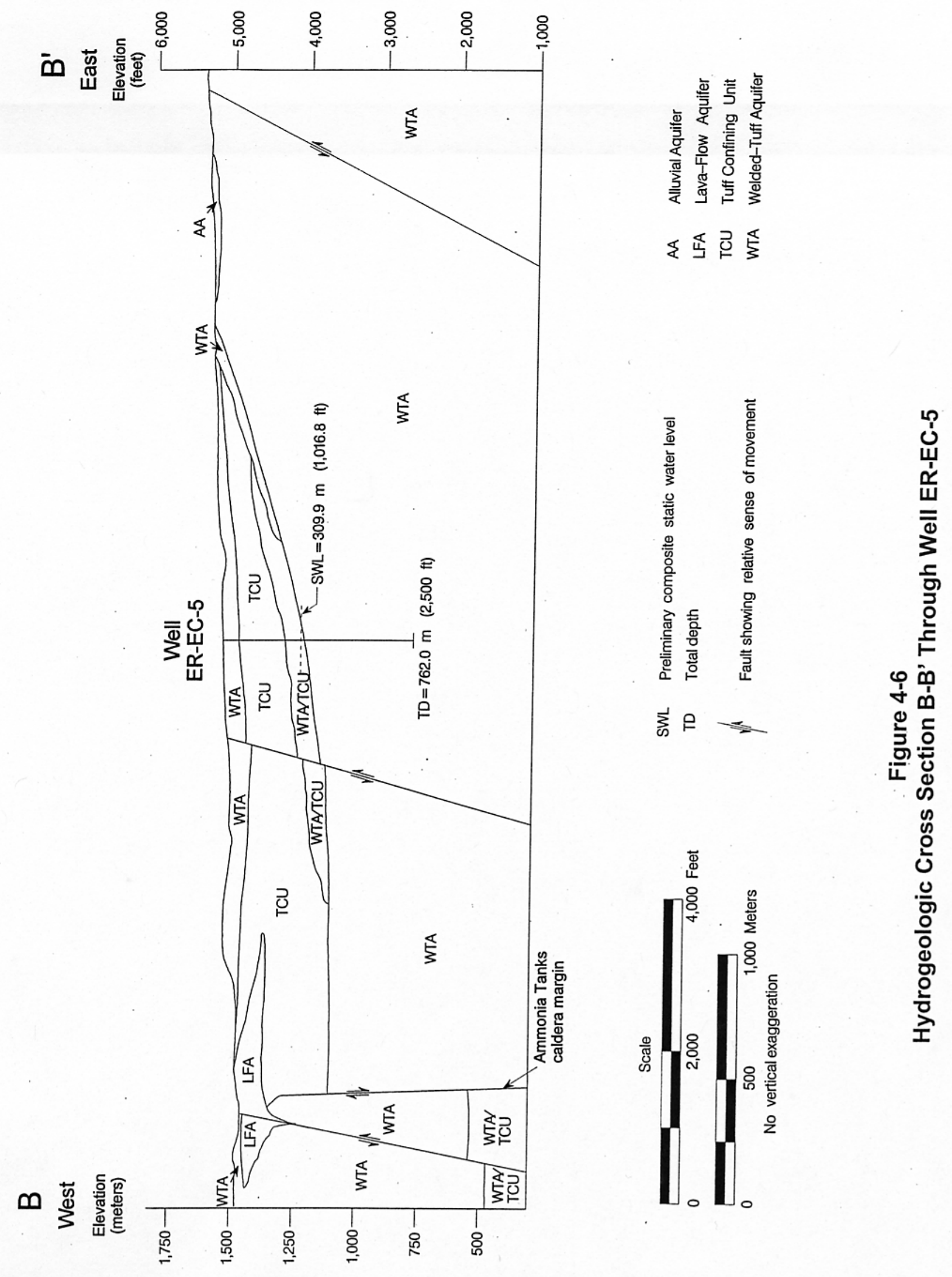


This page intentionally left blank. 


\subsection{Hydrology}

\subsection{Preliminary Water-Level Information}

The elevation of the water table at Well ER-EC-5 was projected to be approximately 1,268 m (4,161 ft), as derived from sparse hydrologic data for this region (IT, 1998). Based on the preconstruction estimate of surface elevation at the site, depth to water was expected to be approximately $280 \mathrm{~m}$ (919 ft) (IT, 1998). Groundwater was first detected at approximately $306.9 \mathrm{~m}$ (1,007 ft). On June 29, 1999, before the 13d -in. surface casing was set, a fluid depth of $332.2 \mathrm{~m}(1,090 \mathrm{ft})$ was obtained from a down-hole camera survey. A fluid depth of $310.3 \mathrm{~m}(1,018 \mathrm{ft})$ was obtained from the chemical $\log$ obtained July 7, 1999, before the completion string was installed. On July 19, 1999, after the completion string was set, IT obtained a fluid-level depth in the well of $310.0 \mathrm{~m}$ (1,017.3 ft). On August 19,1999, over a month after installation of the completion string, IT measured the depth to fluid at $309.9 \mathrm{~m}$ (1,016.8 ft) (IT, 1999). Based on this last composite fluid level depth and the as-built surface elevation of 1,547.5 $\mathrm{m}(5,077.0 \mathrm{ft})$, the fluid level elevation at Well ER-EC-5 is 1,237.5 m $(4,060.2 \mathrm{ft})$. This is approximately $30 \mathrm{~m}(100 \mathrm{ft})$ below the predicted elevation of 1,268 $\mathrm{m}(4,161 \mathrm{ft})$.

\subsection{Water Production}

Water production was estimated by IT field personnel during drilling, on the basis of how much the $\mathrm{LiBr}$ additive was diluted (IT, 1999). The Ammonia Tanks Tuff was the primary water-producing unit at this location, as expected (see Section 4.0). Detectable water production, estimated at about $7.6 \mathrm{lpm}$ (2 gpm), began at the depth of approximately $306.9 \mathrm{~m}(1,007 \mathrm{ft})$ within the Timber Mountain landslide breccia. Water production remained low until a depth of approximately $365.8 \mathrm{~m}(1,200 \mathrm{ft})$ was reached in welded, mafic-rich Ammonia Tanks Tuff, where it began steadily to increase. Water

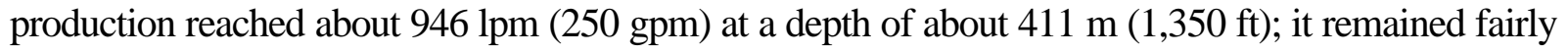
steady to the depth of about $503 \mathrm{~m}(1,650 \mathrm{ft})$, then began to increase again. The production rate again increased at the depth of about $594 \mathrm{~m}(1,950 \mathrm{ft})$ and continued to rise steadily during drilling of the rest of the hole. Water production reached a maximum of over 3,785 lpm (1,000 gpm) below the depth of $701.6 \mathrm{~m}$ (2,302 ft), in the mafic-poor Ammonia Tanks Tuff. Estimated water production rates are presented graphically in Appendix A-1. 


\subsection{Preliminary Thermal Flow Meter Data}

Thermal flow meter (TFM) data, along with temperature, electrical conductivity (EC), and $\mathrm{pH}$ measurements, can characterize borehole fluid variability, which may indicate inflow and outflow zones. The design of the completion string for Well ER-EC-5 was based in part on these data. Desert Research Institute (DRI) personnel made thermal flow meter (TFM) measurements at seven locations between the depths of 387.1 and $749.2 \mathrm{~m}$ (1,270 and 2,458 ft) in Well ER-EC-5 before the completion string was installed. In addition, DRI ran a chemistry log, including temperature, EC, and $\mathrm{pH}$, from 310.6 to $755.9 \mathrm{~m}$ (1,019 to 2,480 ft). Groundwater temperature gradually increased, with only slight fluctuations, from 29.04 degrees Celsius (degrees C) (84.3 degrees Fahrenheit (degrees F) at the top of the fluid column to 30.08 degrees $\mathrm{C}$ ( 86.1 degrees $\mathrm{F})$ at the depth of $755.9 \mathrm{~m}(2,480 \mathrm{ft})$.

Preliminary analysis of a plot of the discrete TFM data points indicates upward groundwater flow at the upper five measurement points, between the depths of 387.1 and $656.7 \mathrm{~m} \mathrm{(1,270} \mathrm{and} \mathrm{1,856} \mathrm{ft).} \mathrm{The}$ lower two measurement points at the depths of 682.7 and $749.2 \mathrm{~m}(2,240$ and 2,458 ft) indicated downward groundwater flow. Plots of the TFM and chemistry log data are reproduced in Appendix D.

\subsection{Radionuclide Monitoring}

Samples of fluid from the well were tested for tritium every hour during drilling. These analyses indicated only natural background levels of tritium, and no man-made radionuclides were encountered during drilling of Well ER-EC-5.

\subsection{Preliminary Groundwater Characterization Sample}

On July 8, 1999, after completion of geophysical logging operations, DRI collected a preliminary groundwater characterization sample (two 5-liter [1.3-gallon] containers) from the open borehole at the depth of $442.0 \mathrm{~m}(1,450 \mathrm{ft})$. Analytical data from this initial sample, collected before formal well development, will provide a basis for comparison with future groundwater chemistry data. 


\subsection{Precompletion and Open-Hole Development}

The only precompletion development conducted in Well ER-EC-5 consisted of circulation and

conditioning of the hole. This process was conducted immediately after TD was reached and prior to geophysical logging. 
This page intentionally left blank. 


\subsection{Well Completion}

\subsection{Introduction}

Well completion refers to the installation in a borehole of a string of pipe or casing that is slotted or screened at one or more locations along its length. The completion process also typically includes emplacement of backfill materials around the casing, with coarse fill such as gravel adjacent to the open intervals and impervious materials such as cement between the open intervals to isolate them. The casing serves as a conduit for insertion of a pump in the well, for inserting devices for measuring the fluid level, and for sampling, so that accurate potentiometric and water chemistry data can be obtained from a known portion of the borehole.

Completion activities at Well ER-EC-5 took place on July 8 to 10, 1999, with the exception of a submersible pump which will be installed at a later date. Figure 7-1 is a schematic of the final wellcompletion design for Well ER-EC-5; Figure 7-2 shows a plan view and profile of the wellhead surface completion; and Table 7-1 is a construction summary for the well. Data for this section were obtained from daily operations and activity reports, casing records, and cementing records provided by the BN Drilling Department. Information from IT's well data report (IT, 1999) was also reviewed for preparation of this section.

\subsection{Well Completion Design}

The final completion design differs slightly from the proposed design, as described in the following paragraphs.

\subsubsection{Proposed Completion Design}

The original completion design (IT, 1998) was based on the assumption that Well ER-EC-5 would penetrate and reach TD in the thick welded-tuff aquifer of the Ammonia Tanks Tuff. The nominal well design called for a single completion string consisting of 51/2-in. stainless steel casing with every other joint slotted, suspended on carbon-steel 7e -in. casing. The slotted portion of the well completion string was to extend through the welded-tuff aquifer of the Ammonia Tanks Tuff. The proposed completion design also called for the isolation (using non-slotted casing) of low transmissivity zones within the completion interval, if such zones could be identified. 
Nevada State Planar (NAD 83, feet): N 20,534,763.8 E 1,669,938.7

Universal Transverse Mercator (Zone 11) (NAD 83, meters): N 4,104,333.9 E 538,621.6

36-in. hole to $10.7 \mathrm{~m}(35.0 \mathrm{ft})$

Cement baskets set at $20.4 \mathrm{~m} \quad(67 \mathrm{ft})$ 26-in. hole to $21.8 \mathrm{~m}(71.5 \mathrm{ft})$

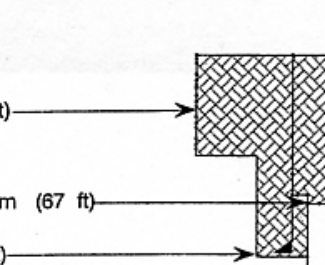
$225.9 \mathrm{~m}(741 \mathrm{ft})$
(estimated from geophysical $\operatorname{logs})$

$219.5 \mathrm{~m}(720 \mathrm{ft})$

$17 \sqrt{ }$-in. hole to $346.3 \mathrm{~m} \quad(1,136.0 \mathrm{ft})-$ $336.8 \mathrm{~m}(1,105 \mathrm{ft})$ $345.6 \mathrm{~m} \quad(1,134 \mathrm{ft})$ $356.3 \mathrm{~m}(1,169 \mathrm{ft})$ $358.7 \mathrm{~m} \quad(1,177 \mathrm{ft})$ $361.8 \mathrm{~m}(1,187 \mathrm{ft})$ $440.1 \mathrm{~m} \cdot(1,444 \mathrm{ft})$ $467.0 \mathrm{~m}(1,532 \mathrm{ft})$ $471.2 \mathrm{~m} \quad(1,546 \mathrm{ft})$ $474.3 \mathrm{~m}(1,556 \mathrm{ft})$

$12 \sqrt{4}$-in. hole to TD

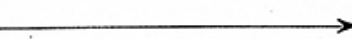

Blank 5 12-in. stainless-steel casing

Crossover subs, from 75 -in. casing

Epoxy-coated 7 58-in. carbon-steel casing to $351.8 \mathrm{~m}(1,154.3 \mathrm{ft})$ 20 -in. casing to $21.3 \mathrm{~m}(70.0 \mathrm{ft})$ 351.8 to $352.4 \mathrm{~m}(1,154.3$ to $1,156.2 \mathrm{ft})$

Blank 5 12-in. stainless steel casing 352.4 to $364.7 \mathrm{~m}(1,156.2$ to $1,196.6 \mathrm{ft})$

Alternating slotted and blank 5 1/2-in. stainless-steel casing 364.7 to $426.3 \cdot \mathrm{m} \quad(1,196.6$ to $1,398.5 \mathrm{ft})$

426.3 to $576.8 \mathrm{~m} \quad(1,398.5$ to $1.892 .4 \mathrm{ft})$

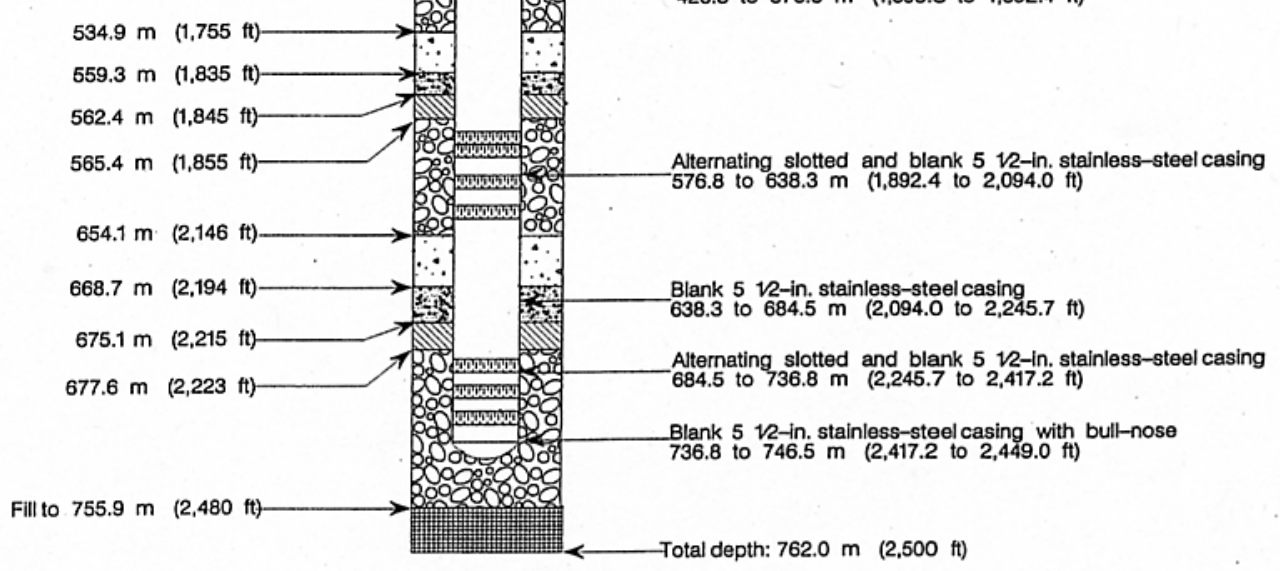

Slotted casing

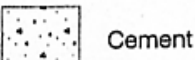

Cement $20 / 40$ silica sand

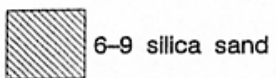

38-in. grave

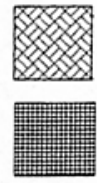

Cement and sand $(7525)$ NOT TO SCALE

Fill
All depths are below ground surface

Additional details regarding casing type, grade, diameter, etc. are provided in Appendlx A-2.

Figure 7-1

As-Built Completion Schematic for Well ER-EC-5 


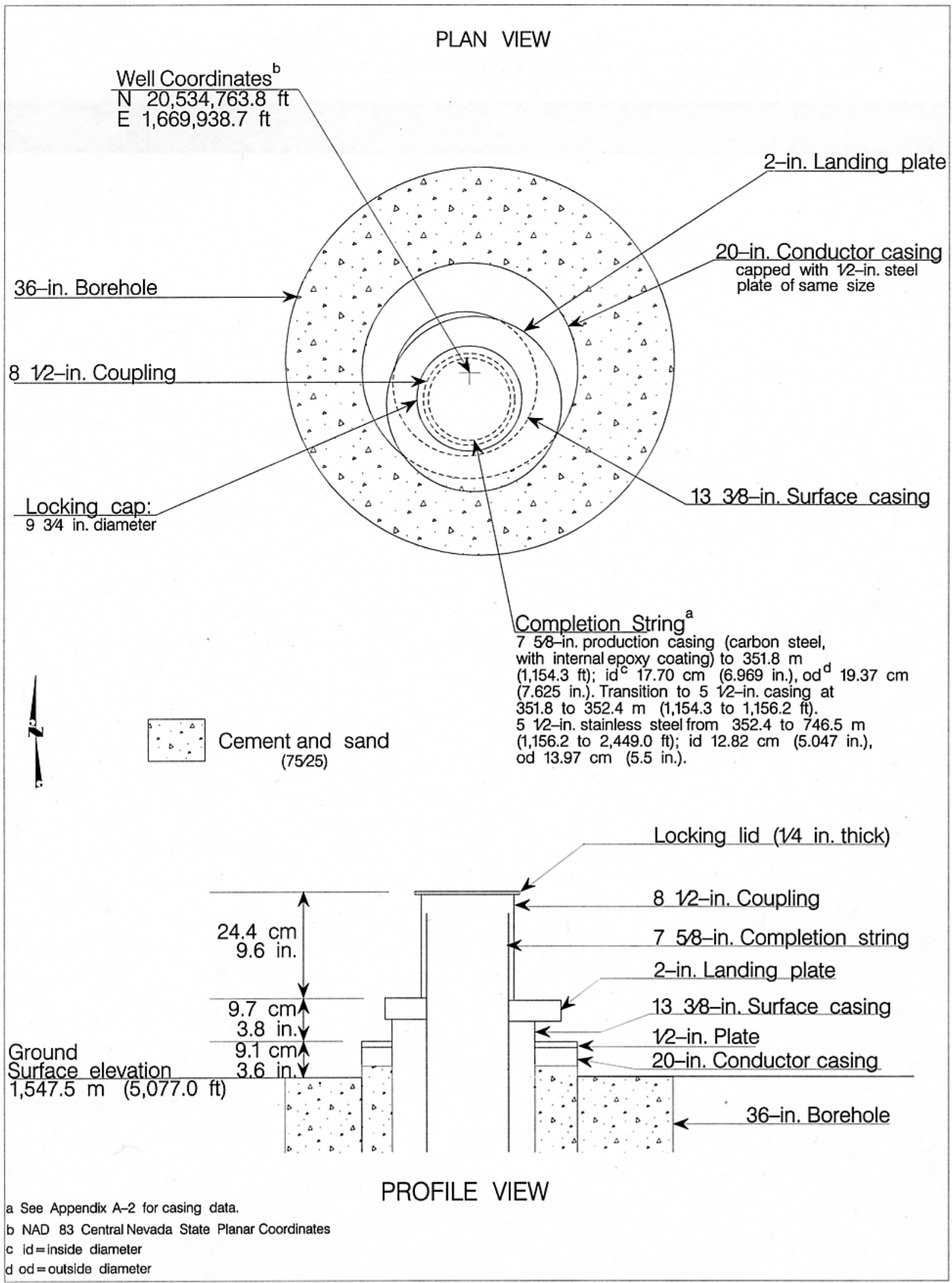

Figure 7-2

Wellhead Diagram for Well ER-EC-5 
Table 7-1

Well ER-EC-5 Completion String Construction Summary

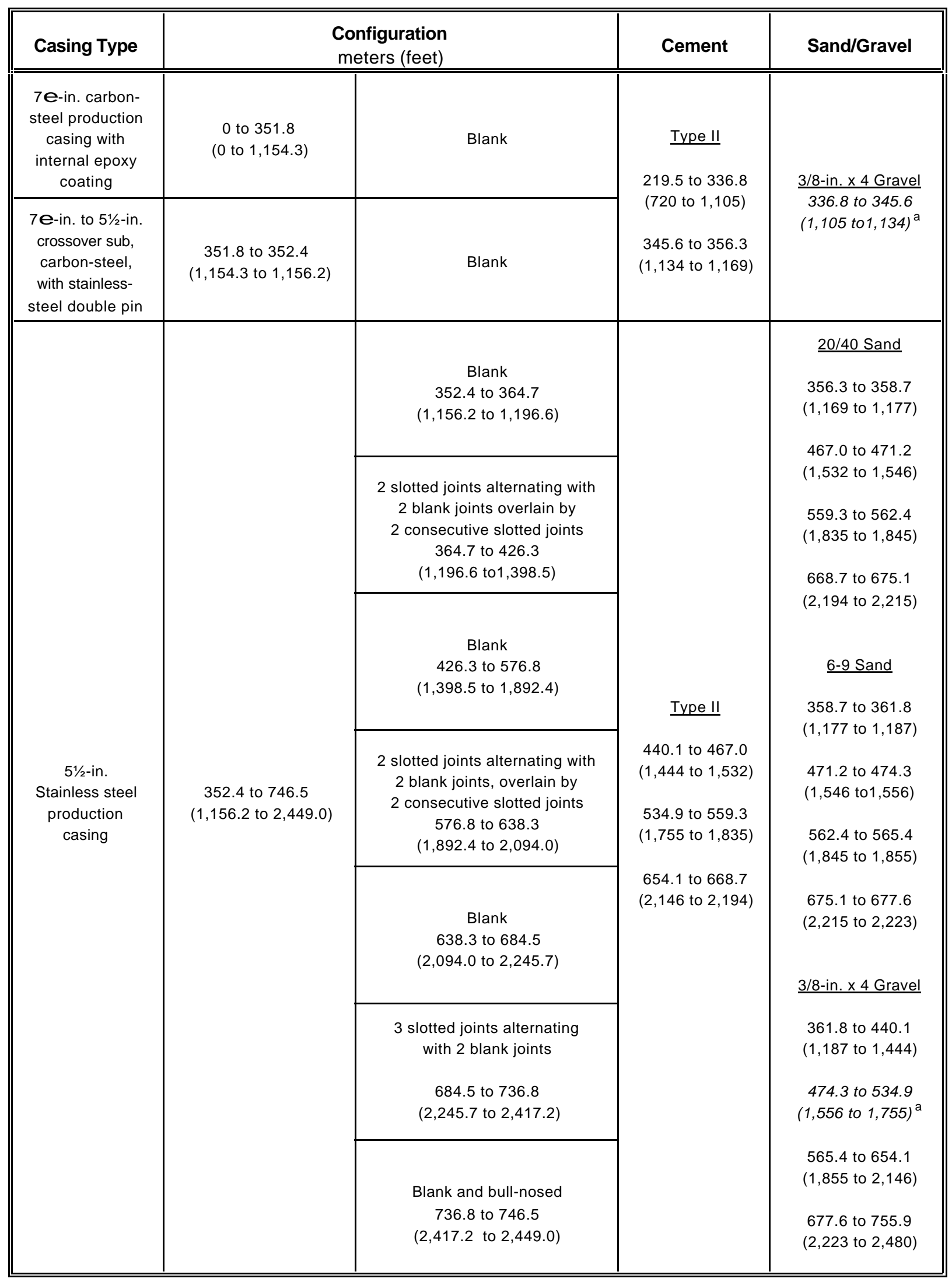




\subsubsection{As-Built Completion Design}

The design of the Well ER-EC-5 completion was determined through consultation with members of the UGTA TWG, on the basis of on-site evaluation of data such as lithology and water production, drilling data (lost circulation, etc.), data from geophysical logs (particularly caliper, down-hole video, acoustic fracture log), and from thermal-flow and water chemistry logs.

The as-built completion design for Well ER-EC-5 provides access to three different parts of the Ammonia Tanks Tuff welded-tuff aquifer (Figure 7-1). The composition of the string summarized here is detailed on Table 7-1, and the casing materials are listed in Appendix A-2. The lower section of the completion string, from $352.4 \mathrm{~m}$ to $746.5 \mathrm{~m}(1,156.2$ to 2,449.0 ft), is type T304L stainless-steel casing with an outside diameter of $14.0 \mathrm{~cm}$ (5.5 in.) and an inside diameter of $12.819 \mathrm{~cm}$ (5.047 in.). The top of the 51/2-in. casing is approximately $42 \mathrm{~m}$ (139 ft) below the static fluid level. The bottom $0.5-\mathrm{m}(1.65-\mathrm{ft})$ joint is a blank with a bull-nose sub which served as a guide shoe so that the string did not catch on ledges, etc., as it was inserted in the open hole. Above the 51/2-in. casing, a 0.6-m (1.95-ft) long crossover sub serves as the transition to the upper part of the string, which is $7 \mathrm{e}$-in. carbon-steel production casing with an internal epoxy coating.

All three screened intervals are located in welded ash-flow tuff. The lowest zone was constructed in moderately to densely welded, mafic-poor Ammonia Tanks Tuff, and the upper two zones were installed in moderately welded mafic-rich Ammonia Tanks Tuff (see Figure 4-3 for an illustration of gravel-pack locations relative to hydrogeologic units). The casing in the lowest screened interval, 684.5 to $736.8 \mathrm{~m}$ (2,245.7 to $2,417.2 \mathrm{ft})$, consists of three slotted joints alternating with two blank joints. The middle slotted interval, 576.8 to $638.3 \mathrm{~m}$ (1,892.4 to 2,094.0 ft), spans a region where water production was found to increase during drilling. The string in this interval consists of two slotted joints alternating with two blank joints, overlain by two consecutive slotted joints. The uppermost slotted interval, 364.7 to $426.3 \mathrm{~m}$ (1,196.6 to 1,398.5 ft), also spans an area of increased water flow, and consists of two slotted joints alternating with two blank joints overlain by two consecutive slotted joints.

The openings in each slotted casing joint are $0.198 \mathrm{~cm}(0.078 \mathrm{in}$.$) wide and 5.1 \mathrm{~cm}(2 \mathrm{in}$.$) long, cut in$ rings of 18 slots (spaced 20 degrees apart around the joint). The rings are spaced $15.2 \mathrm{~cm}$ (6 in.) apart (center to center), and the longitudinal centers of the slots in each ring are staggered 10 degrees from the slot centers in the next ring. No slots are cut within $0.6 \mathrm{~m}(2 \mathrm{ft})$ of the ends of the slotted joints to assure that the strength of the connections is not degraded. 


\subsubsection{Rationale for Differences between Actual and Proposed Well Design}

Well ER-EC-5 was completed as planned in the Ammonia Tanks Tuff. The basic plan of installing a single string consisting of larger diameter carbon-steel casing above the water table and smaller diameter stainless-steel casing in the saturated zone was accomplished. However, information obtained about water production and water flow during and after drilling allowed the selection of three intervals within the welded-tuff aquifer with potentially differing hydraulic character as isolated completion zones.

\subsection{Well Completion Method}

A "tremie" line and the completion string were landed after a brief period of circulation and conditioning of the hole. The three completion zones were gravel-packed and then isolated from each other with sand and cement barriers. Caliper logs were used to calculate the volumes of cement needed during well completion. Well-construction materials were inspected according to relevant procedures; standard decontamination procedures were employed to prevent the introduction of contaminants into the well.

The filter pack around each open interval consists of $0.95-\mathrm{cm}(\mathrm{d}$-in.) by 4-mesh washed gravel, with 6-9 Colorado silica sand directly above the gravel, and 20/40 silica sand on top of the 6-9 sand. In this stemming design, developed by the UGTA program at the NTS, the layer of 20/40 sand serves as a barrier to any fluids that might seep from the cement above, preventing cement fluids from contaminating the groundwater (fluids from the cement would have the effect of drastically raising the $\mathrm{pH}$ of the groundwater). The underlying layer of 6-9 sand prevents the 20/40 sand from infiltrating the gravel-pack. All cement used in the well completion was type II Portland cement with no additives. A clear-water pre-flush and back-flush were made at each stage of cement emplacement. Gravel, sand, and cement were emplaced through a $2 f$-in. Hydril ${ }^{\circledR}$ tremie line that was withdrawn as the completion process progressed. A Nuclear Annulus Investigation Log was used to monitor the emplacement of stemming materials. As-built positions of the well materials are shown on Figure 7-1 and listed in Table 7-1.

Stemming of the hole began with the first gravel pack emplaced from 755.9 to $677.6 \mathrm{~m}(2,480$ to 2,223 ft), outside the lowest slotted interval, on top of $6.1 \mathrm{~m}(20 \mathrm{ft})$ of fill at the bottom of the hole. This gravel pack is topped by a sand barrier to the depth of $668.7 \mathrm{~m}(2,194 \mathrm{ft})$, followed by cement, poured in one stage up to $654.1 \mathrm{~m}(2,146 \mathrm{ft})$. The second gravel pack was placed between 654.1 and $565.4 \mathrm{~m}(2,146$ and 1,855 ft), adjacent to the middle slotted interval; this gravel was topped with sand to the depth of $559.3 \mathrm{~m}(1,835 \mathrm{ft})$, and cement to $534.9 \mathrm{~m}(1,755 \mathrm{ft})$. A layer of gravel was placed between $534.9 \mathrm{~m}$ and $474.3 \mathrm{~m}$ (1,755 and 1,556 ft), adjacent to a blank casing interval, and is capped 
with a sand barrier to the depth of $467.0 \mathrm{~m}(1,532 \mathrm{ft})$, and cement to $440.1 \mathrm{~m}(1,444 \mathrm{ft})$. Another gravel pack, adjacent to the uppermost slotted interval, extends from 440.1 to $361.8 \mathrm{~m}(1,444$ to $1,187 \mathrm{ft})$, and is capped by sand to the depth of $356.3 \mathrm{~m}(1,169 \mathrm{ft})$. During emplacement of the upper cement cap (above the depth of $356.3 \mathrm{~m}[1,169 \mathrm{ft}]$ ), the volume of cement used was significantly greater than calculated for the volume of the borehole interval. To save time waiting on cement deliveries and to stem any voids that might be taking the excess cement, a stage of gravel was placed outside blank $7 \mathrm{e}$-in. casing in the interval 345.6 to $336.8 \mathrm{~m}$ (1,134 to 1,105 ft). This gravel is capped directly by cement to the depth of $219.5 \mathrm{~m}(720 \mathrm{ft})$.

The drill rig was released after cementing was completed. Hydrologic testing was planned as a separate effort, so a pump was not installed in the well and no well-development or pumping tests were conducted immediately after completion. 
This page intentionally left blank. 


\subsection{Actual versus Planned Costs and Scheduling}

The BN cost model developed on the basis of the Well ER-EC-5 drilling plan projected that it would require 22 days to drill the surface and main holes, log, and complete the well. The actual time spent to construct the well was 17 days. A graphical comparison, by day, of planned and actual wellconstruction activities is presented in Figure 8-1.

The cost analysis for Well ER-EC-5 begins with drilling of the surface hole, after construction of the conductor hole. The construction cost for Well ER-EC-5 includes all drilling costs: charges by the drilling subcontractor; charges by other support subcontractors (including compressor services, drilling fluids, bits, casing services, down-hole tools, and geophysical logging); and charges by BN for mobilization and demobilization of equipment, cementing services, completion materials, radiation technicians, inspection services, and geotechnical consultation. The cost of building the access road, the drill pad, and the sumps is not included, and the cost of well-site support by IT is not included.

The total planned cost for Well ER-EC-5 was $\$ 1,063,081$. The actual cost was $\$ 1,139,633$, or 6.7 percent more than the planned cost. Figure 8-2 presents a comparison of the planned (baseline task plan) and actual costs, by day, for drilling and completing Well ER-EC-5. 


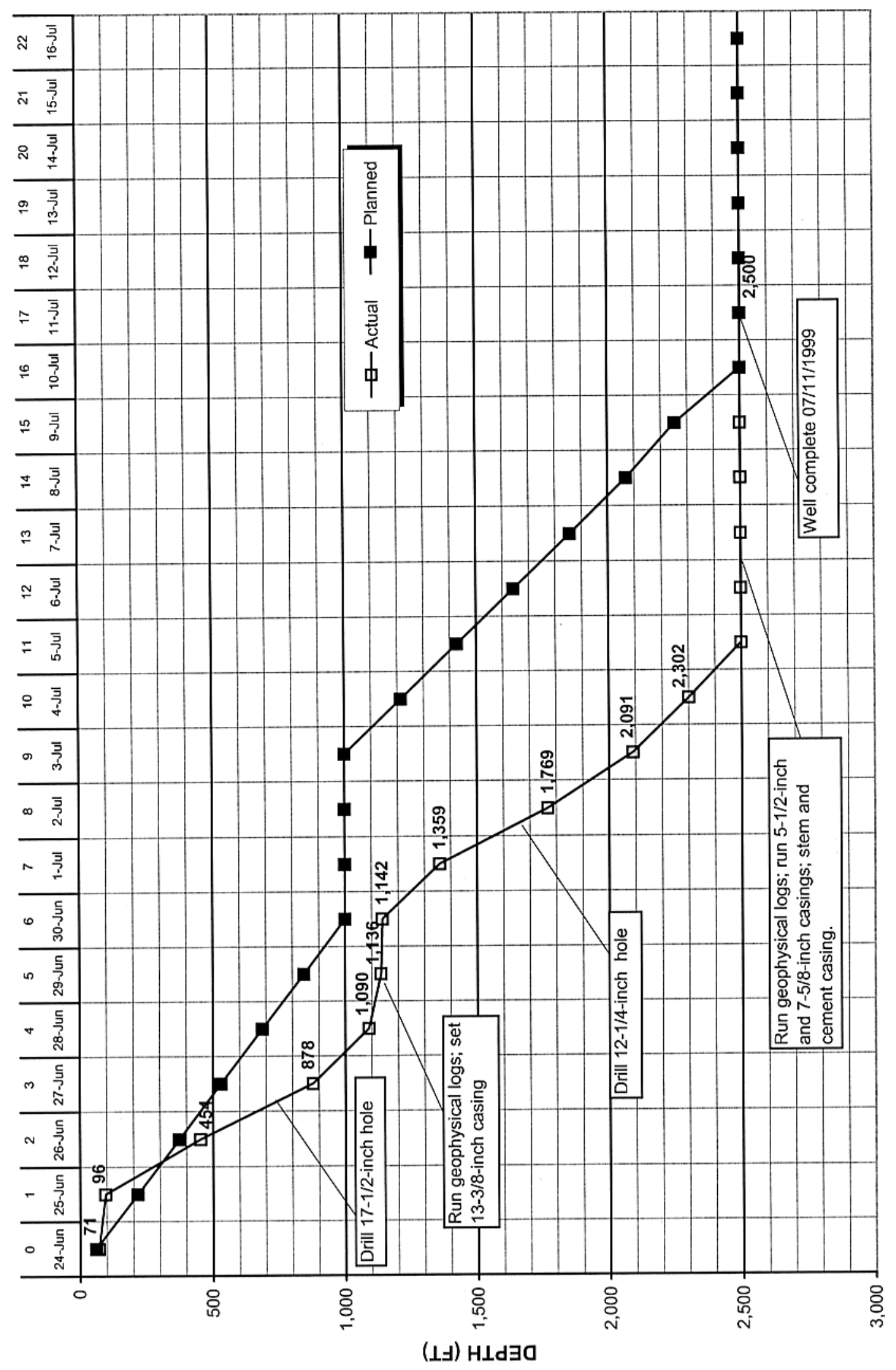

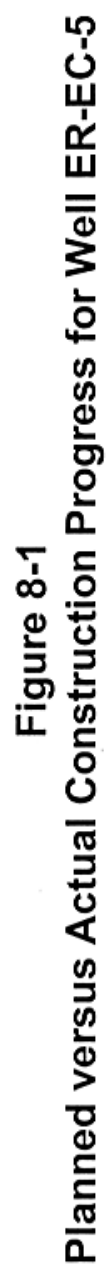



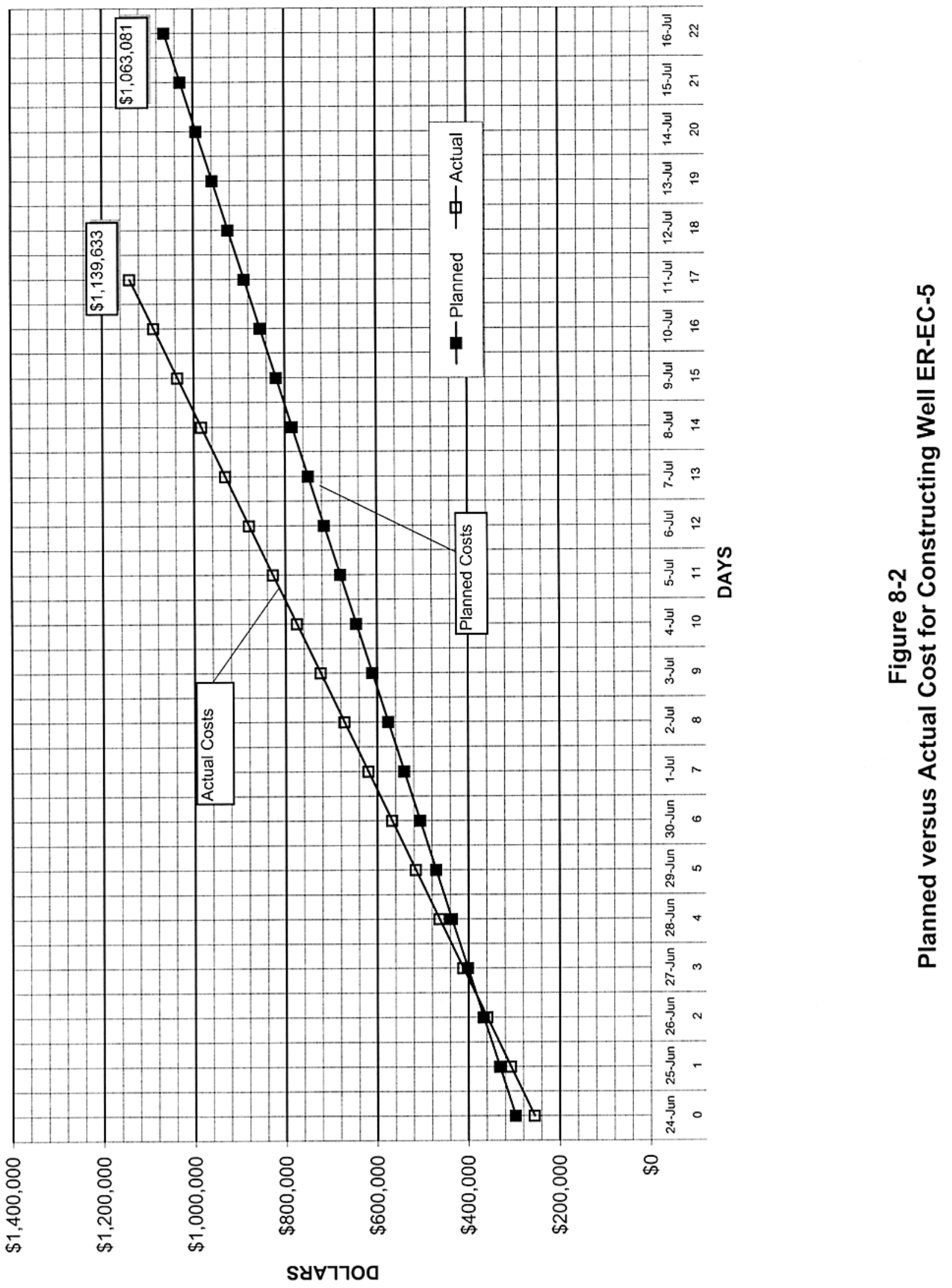
This page intentionally left blank. 


\subsection{Summary, Recommendations, and Lessons Learned}

\subsection{Summary}

Drilling subcontractor activities at Well ER-EC-5 commenced on June 24, 1999, and concluded on July 4, 1999, when the planned TD of $762.0 \mathrm{~m}$ (2,500 ft) was reached. After geophysical logging, the completion string was installed and gravel-packed, and the hole was stemmed to the depth $219.5 \mathrm{~m}$ (720.0 ft) on July 8 to 10, 1999. Crews worked on a 7-days-a-week, 24-hours-a-day schedule for most of the operation. Seventeen working days were expended to drill the surface and main holes, conduct geophysical logging, and install the completion string. No significant problems were encountered during construction of Well ER-EC-5.

No radionuclides above background were encountered in the groundwater produced from Well ER-EC-5. The static fluid level consistently stabilized at the depth of approximately $310.2 \mathrm{~m}$ (1,018 ft) during drilling. IT personnel obtained a fluid level of $309.9 \mathrm{~m}(1,016.8 \mathrm{ft})$ on August 19, 1999, 40 days after the completion string was installed (IT, 1999).

Composite drill cuttings were collected every $3 \mathrm{~m}$ (10 ft) from $21.3 \mathrm{~m}$ (70 ft) to TD. Eighteen sidewall core samples were collected in the interval $349.6 \mathrm{~m}$ to $745.2 \mathrm{~m}$ (1,147 to 2,445 ft). Geophysical logging was conducted in the upper part of the hole before installation of the surface casing, and in the lower part of the hole before installation of the completion string. Some of these logs were used to aid in construction of the well, while others help to verify the geology and determine the hydrologic characteristics of the rocks.

A single completion string with three gravel-packed, slotted intervals was installed in Well ER-EC-5. The string of 51/2-in. stainless-steel casing installed below the water table is suspended from $7 e$-in. carbon-steel casing (with an internal epoxy coating) which extends to the surface. The open intervals in the $5 \frac{1}{2}$-in. casing are centered within the gravel-pack intervals located at $361.8 \mathrm{~m}$ to $440.1 \mathrm{~m}$ ( 1,187 to $1,444 \mathrm{ft}) ; 565.4 \mathrm{~m}$ to $654.1 \mathrm{~m}$ ( 1,855 to $2,146 \mathrm{ft})$; and $677.6 \mathrm{~m}$ to $755.9 \mathrm{~m} \mathrm{(2,223} \mathrm{to}$ 2,480 ft). The two uppermost intervals are open to welded-tuff aquifers of the mafic-rich Ammonia Tanks Tuff. The lowermost interval is open to a welded-tuff aquifer of the mafic-poor Ammonia Tanks Tuff. 


\subsection{Recommendations}

The planned pump installation, well development, groundwater sampling, and hydrologic testing must be conducted at Well ER-EC-5 to accomplish the remaining objectives for this well-construction effort.

\subsection{Lessons Learned}

The efficiency of drilling and constructing wells to obtain hydrogeologic data in support of the UGTA project continues to improve as experience is gained with each new well, yet each new well produces some "lessons learned" that can be applied to improve future well-construction projects. Very few problems were encountered during construction of Well ER-EC-5, however, the following items were noted:

- The success in drilling this hole again demonstrated the value of maintaining the correct balance of air volume, foam, and polymer in the upper unsaturated zone when using air-foam drill fluid in direct circulation. In volcanic rocks, careful attention to the amount of soap and polymer in the fluid mix prevents most borehole sloughing problems and results in savings in drilling time and cost.

- It was noted that the geophysical logging subcontractor arrived to conduct the second logging suite (in the saturated zone) with several tools in inoperable condition. The delays caused by trouble-shooting and repair of logging tools, waiting for shipments of working tools, and rerunning logs in intervals where data quality was poor, might have been avoided if the tools had been tested for operability before they were brought to the job. 


\subsection{References}

Bechtel Nevada, 1999a. Western Pahute Mesa/Oasis Valley (WPM-OV) Investigation Wells SiteSpecific Health and Safety Plan (SSHASP). February 1999. Las Vegas, NV.

Bechtel Nevada, 1999b, Drilling Program for Underground Test Area (UGTA) Western Pahute Mesa/Oasis Valley (WPM-OV) Investigation Well ER-EC-5 - Original, Drilling Work Plan Number D-006-002.99, June 25, 1999, Las Vegas, NV.

Bechtel Nevada, 2002. A Hydrostratigraphic Model and Alternatives for the Groundwater Flow and Contaminant Transport Model of Corrective Action Units 101 and 102: Central and Western Pahute Mesa, Nye County, Nevada. DOE/NV/11718--706. Las Vegas, NV.

BN, see Bechtel Nevada.

Byers, F. M., Jr., and W. L. Hawkins, 1981. Geology of Drill Hole UE18t and Area 18, Timber Mountain Caldera Moat, Nevada Test Site, U. S. Geological Survey Open-File Report USGS474-312. Denver, CO.

Carr, W. J., F. M. Byers, Jr., and E. C. Jenkins, 1968. Geology of Drill Hole UE18r, Timber Mountain Caldera, Nevada Test Site, U. S. Geological Survey Technical Letter: Special Studies-69. Denver, CO.

DOE, see U. S. Department of Energy.

Grauch, V. J. S., D. A. Sawyer, C. J. Fridrich, and M. R. Hudson, 1997. Geophysical Interpretations West of and Within the Northwestern Part of the Nevada Test Site, U.S. Geological Survey Open-File Report 97-476. Denver, CO.

IT, see IT Corporation.

IT Corporation, 1998. Western Pahute Mesa - Oasis Valley Hydrogeologic Investigation Wells Drilling and Completion Criteria, ITLV/13052-049. Prepared for DOE/NV. Las Vegas, NV.

IT Corporation, 1999. Written communication prepared for DOE/NV. Subject: "Western Pahute Mesa - Oasis Valley ER-EC-5 Well Data Report,” September 1999. Las Vegas, NV.

Lipman, P. W., W. D. Quinlivan, W. J. Carr, and R. E. Anderson, 1966. Thirsty Canyon SE Quadrangle, Nye County, Nevada. U.S. Geological Survey Map GQ-489. Washington, D. C.

Sawyer, D. A., J. J. Fleck, M. A. Lanphere, R. G. Warren, and D. E. Broxton, 1994. "Episodic Caldera Volcanism in the Miocene Southwest Nevada Volcanic Field: Revised Stratigraphic Caldera Framework, ${ }^{40} \mathrm{Ar} /{ }^{39} \mathrm{Ar}$ Geochronology, and Implications for Magmatism and Extension." Geological Society of America Bulletin, v. 67, n. 10, pp. 1,204-1,318. 
U.S. Department of Energy, 1996a. Attachment 1, "Fluid Management Plan for the Underground Test Area Subproject." In Underground Test Area Subproject Waste Management Plan, Revision 1, DOE/NV--343. Las Vegas, NV.

U.S. Department of Energy, 1996b. Underground Test Area Subproject Waste Management Plan, Rev. 1, DOE/NV--343. Las Vegas, NV.

U.S. Department of Energy, 1998. Nevada Environmental Restoration Project Health and Safety Plan, Revision 3, February 1998, Document Number AMEM-01-001. Las Vegas, NV.

U.S. Department of Energy, 2003. Completion Report for Well ER-18-2, DOE/NV/11718--388. Las Vegas, NV.

Wahl, R. R., D. A. Sawyer, M. D. Carr, S. A. Minor, J. C. Cole, WC Swadley, R. J. Laczniak, R. G. Warren, K. S. Green, and C. M. Engle, 1997. Digital Geologic Map of the Nevada Test Site Area, Nevada, U. S. Geological Survey Open-File Report 97-140, scale, 1:120,000

Warren, R. G., 1994. Written communication to Ed Price, GeoTrans, Las Vegas, NV. Subject: "Structural Elements and Hydrogeologic Units of the Southwestern Nevada Volcanic Field," Attachment to Los Alamos National Laboratory letter, May 1994. 19 pp., 4 figures, structural block model map, 2 cross sections.

Warren, R. G. 2003. Written communication via E-mail to Lance Prothro, Bechtel Nevada, Las Vegas, NV, dated June 26, 2003. Subject: Analytical results for samples from Well ER-EC-5.

Warren, R. G., G. L. Cole, and D. Walther, 2000. A Structural Block Model for the ThreeDimensional Geology of the Southwestern Nevada Volcanic Field. Los Alamos National Laboratory Report LA-UR-00-5866.

Warren, R. G., D. A. Sawyer, F. M. Byers, Jr., and G. L. Cole, 2003. A Petrographic, Geochemical, and Geophysical Database and Stratigraphic Framework for the Southwestern Nevada Volcanic Field. Los Alamos National Laboratory Report LA-UR-03-1503, 54 pp. 


\section{Appendix A \\ Drilling Data}

A-1 Drilling Parameter Log for Well ER-EC-5

A-2 Casing Data for Well ER-EC-5

A-3 Well ER-EC-5 Drilling Fluids and Cement Composition 
Appendix A-1

Drilling Parameter Log for Well ER-EC-5 


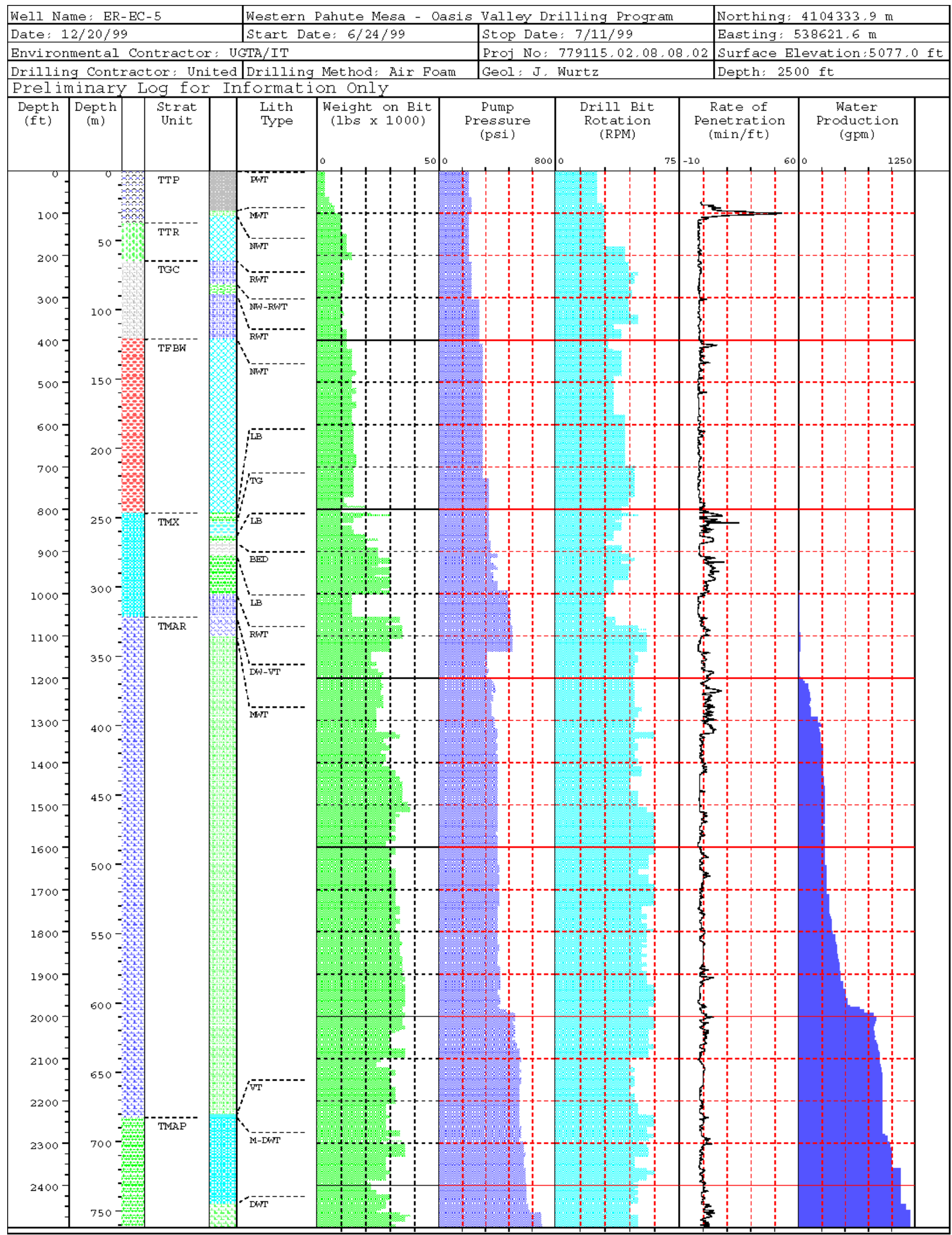


This page intentionally left blank.

A-1-2 
Appendix A-2

Casing Data for Well ER-EC-5 


\section{Casing Data for Well ER-EC-5}

\begin{tabular}{||c|c|c|c|c|c|c|c||}
\hline CASING & $\begin{array}{c}\text { Depth Interval } \\
\text { meters } \\
\text { (feet) }\end{array}$ & Type & Grade & $\begin{array}{c}\text { Outside } \\
\text { Diameter } \\
\text { centimeter } \\
\mathrm{S} \\
\text { (inches) }\end{array}$ & $\begin{array}{c}\text { Inside } \\
\text { Diameter } \\
\text { centimeters } \\
\text { (inches) }\end{array}$ & $\begin{array}{c}\text { Wall } \\
\text { Thickness } \\
\text { centimeters } \\
\text { (inches) }\end{array}$ & $\begin{array}{c}\text { Weight } \\
\text { per foot } \\
\text { (pounds/ } \\
\text { foot) }\end{array}$ \\
\hline $\begin{array}{c}\text { Conductor } \\
\text { Casing }\end{array}$ & $\begin{array}{c}0 \text { to } 21.3 \\
\text { (0 to } 70.0)\end{array}$ & $\begin{array}{c}\text { Carbon } \\
\text { Steel }\end{array}$ & $\mathrm{K} 55$ & $\begin{array}{c}50.80 \\
(20)\end{array}$ & $\begin{array}{c}48.575 \\
(19.124)\end{array}$ & $\begin{array}{c}1.113 \\
(0.438)\end{array}$ & 94 \\
\hline $\begin{array}{c}\text { Surface } \\
\text { Casing }\end{array}$ & $\begin{array}{c}0 \text { to } 342.6 \\
(0 \text { to } 1,124.1)\end{array}$ & $\begin{array}{c}\text { Carbon } \\
\text { Steel }\end{array}$ & $\mathrm{K} 5$ & $\begin{array}{c}33.97 \\
(13.375)\end{array}$ & $\begin{array}{c}31.788 \\
(12.515)\end{array}$ & $\begin{array}{c}1.092 \\
(0.430)\end{array}$ & 61.0 \\
\hline $\begin{array}{c}\text { Completion } \\
\text { Casing and } \\
\text { crossover } \\
\text { sub }\end{array}$ & $\begin{array}{c}0 \text { to } 352.4 \\
(0 \text { to } 1,156.2)\end{array}$ & $\begin{array}{c}\text { Carbon } \\
\text { Steel, } \\
\text { epoxy } \\
\text { coated }\end{array}$ & $\mathrm{N} 80$ & $\begin{array}{c}19.37 \\
(7.625)\end{array}$ & $\begin{array}{c}17.701 \\
(6.969)\end{array}$ & $\begin{array}{c}0.833 \\
(0.328)\end{array}$ & 26.4 \\
\hline $\begin{array}{c}\text { Completion } \\
\text { Casing }\end{array}$ & $\begin{array}{c}352.4 \text { to } 746.5 \\
(1,156.2 \text { to } 2,449.0)\end{array}$ & $\begin{array}{c}\text { Stainles } \\
\text { s Steel }\end{array}$ & T304L & $\begin{array}{c}13.97 \\
5.5\end{array}$ & $\begin{array}{c}12.819 \\
(5.047)\end{array}$ & $\begin{array}{c}0.577 \\
(0.227)\end{array}$ & 14.6 \\
\hline
\end{tabular}


This page intentionally left blank.

A-2-2 
Appendix A-3

Well ER-EC-5 Drilling Fluids and Cement Composition 
Table A-3-1

Well ER-EC-5 Drilling Fluids

\begin{tabular}{|c|}
\hline Typical Air-Foam/Polymer Mix ${ }^{a}$ \\
\hline $\begin{array}{c}8 \text { to } 28 \text { liters ( } 2 \text { to } 7 \text { gallons) Acrylafoam }{ }^{\circledR b} \text { and } \\
4 \text { to } 11 \text { liters ( } 1 \text { to } 3 \text { gallons) Acrylavis }{ }^{\circledR b} \\
\text { per } \\
7,949 \text { liters (50 barrels) water }\end{array}$ \\
\hline
\end{tabular}

a During air-foam /polymer drilling below 21.8 meters (71.5 feet), various proportions of polymer were added to suit conditions.

b Acrylafoam ${ }^{\circledR}$ foaming agent and Acrylavis ${ }^{\circledR}$ polymer additive are products of Enterprise Drilling Fluids, Inc. NOTES:

1. All water used to mix drilling fluids for Well ER-EC-5 came from the Coffer Well.

2. Air with water spray for dust control was used while augering the conductor hole from the ground surface to the depth of $21.8 \mathrm{~m}(71.5 \mathrm{ft})$.

3. A concentrated solution of lithium bromide was added to all introduced fluids to make up a final concentration of 17 to 27 milligrams per liter (17 to 27 parts per million).

Table A-3-2

Well ER-EC-5 Cement Composition

\begin{tabular}{|c|c|c|c|}
\hline $\begin{array}{c}\text { Cement } \\
\text { Composition }\end{array}$ & $\begin{array}{c}\text { 20-inch Conductor } \\
\text { Casing }\end{array}$ & $\begin{array}{c}\text { 13d -inch Surface } \\
\text { Casing }\end{array}$ & Completion \\
\hline $\begin{array}{l}\text { Type II plus } 25 \\
\text { percent sand }\end{array}$ & $\begin{array}{l}0 \text { to } 21.8 \mathrm{~m}^{\mathrm{a}} \\
\left(0 \text { to } 71.5 \mathrm{ft}^{\mathrm{b}}\right)\end{array}$ & $\begin{array}{c}\text { Above cement } \\
\text { baskets } \\
0 \text { to } 20.4 \mathrm{~m} \\
(0 \text { to } 67.0 \mathrm{ft})\end{array}$ & Not used \\
\hline Type II & Not used & $\begin{array}{l}225.9^{\mathrm{c}} \text { to } 346.3 \mathrm{~m} \\
\left(741^{\mathrm{C}} \text { to } 1,136.0 \mathrm{ft}\right)\end{array}$ & $\begin{array}{l}219.5 \text { to } 336.8 \mathrm{~m} \\
(720 \text { to } 1,105 \mathrm{ft}) \\
345.6 \text { to } 356.3 \mathrm{~m} \\
(1,134 \text { to } 1,169 \mathrm{ft}) \\
440.1 \text { to } 467.0 \mathrm{~m} \\
(1,444 \text { to } 1,532 \mathrm{ft}) \\
534.9 \text { to } 559.3 \mathrm{~m} \\
(1,755 \text { to } 1,835 \mathrm{ft}) \\
654.1 \text { to } 668.7 \mathrm{~m} \\
(2,146 \text { to } 2,194 \mathrm{ft})\end{array}$ \\
\hline
\end{tabular}

a $\operatorname{meter}(\mathrm{s}) \quad \mathrm{b}$ foot (feet) $\quad \mathrm{c}$ estimated 
This page intentionally left blank.

A-3-2 
Appendix B

Well ER-EC-5 Fluid Management Data 


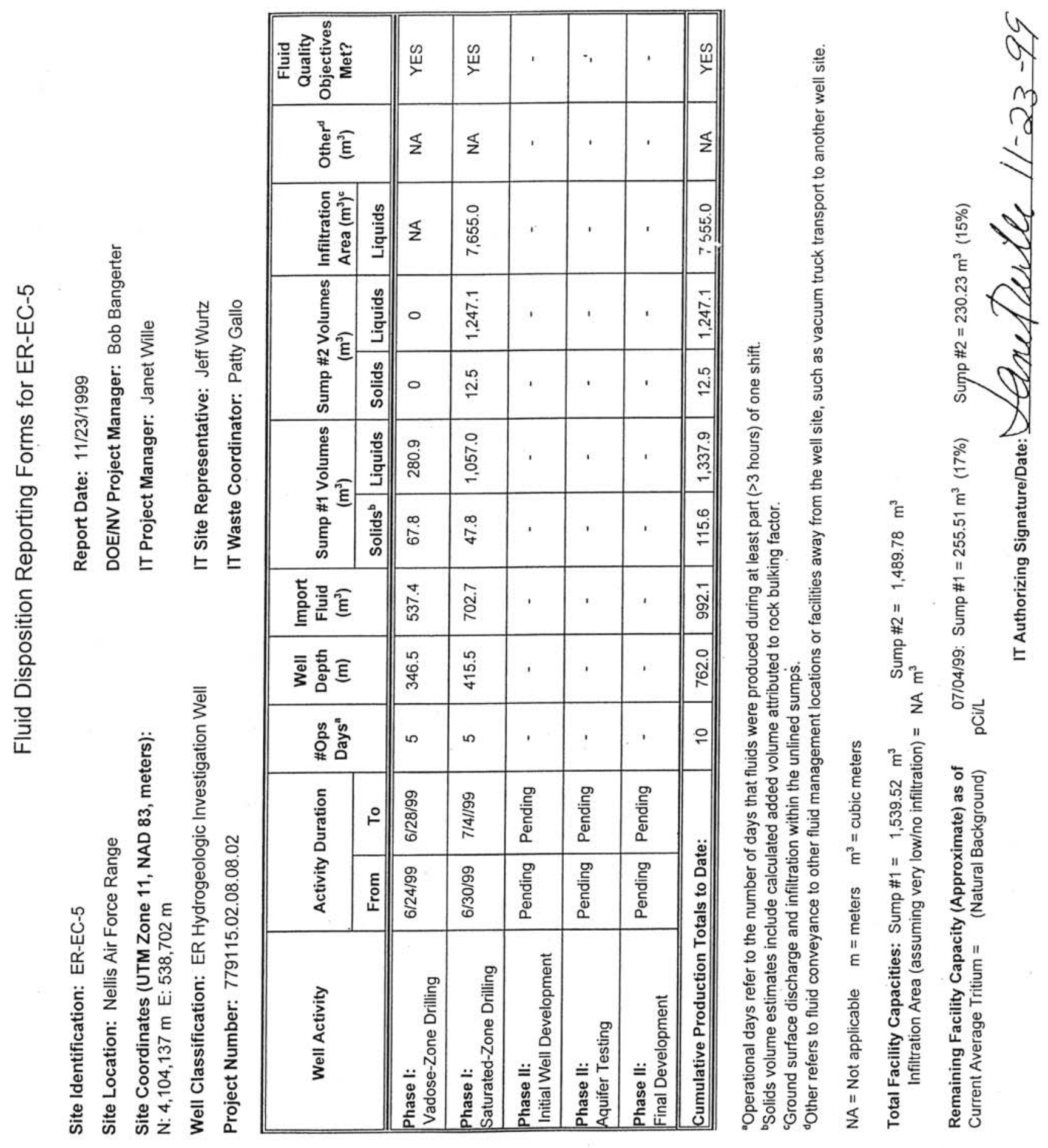


Preliminary Analytical Results for Fluid Management Samples at Well ER-EC-5

\begin{tabular}{|c|c|c|c|c|c|c|c|c|c|c|c|c|c|c|}
\hline \multirow{2}{*}{$\begin{array}{l}\text { Sample } \\
\text { Number }\end{array}$} & \multirow{2}{*}{$\begin{array}{l}\text { Date \& } \\
\text { Time } \\
\text { Collected }\end{array}$} & \multirow{2}{*}{ Comment } & & \multicolumn{8}{|c|}{ RCRA Metals (milligrams per liter) } & \multirow{2}{*}{$\begin{array}{l}\text { Gross } \\
\text { Alpha } \\
\text { (pCi/L) }\end{array}$} & \multirow{2}{*}{$\begin{array}{c}\text { Gross } \\
\text { Beta } \\
\text { (pCi/L) }\end{array}$} & \multirow{2}{*}{$\begin{array}{c}\text { Tritiu } \\
\mathbf{m} \\
(\mathrm{pCi} / \mathrm{L})\end{array}$} \\
\hline & & & & Arsenic & Barium & Cadmium & $\begin{array}{l}\text { Chromiu } \\
\mathrm{m}\end{array}$ & Lead & Selenium & Silver & Mercury & & & \\
\hline \multirow{2}{*}{ EC-5-06299-1 } & \multirow{2}{*}{$\begin{array}{c}04 / 29 / 1999 \\
11: 30\end{array}$} & \multirow{2}{*}{$\begin{array}{l}\text { Sample } \\
\text { collected from } \\
\text { sump \#1 }\end{array}$} & Total $^{\mathrm{a}}$ & 0.0232 & 0.315 & $\cup 0.0002$ & 0.029 & 0.0443 & 0.0088 & U 0.0005 & B 0.00056 & N/Anl & N/Anl & $\mathrm{N} / \mathrm{Anl}$ \\
\hline & & & $\underset{\mathrm{b}}{\text { Dissolved }}$ & 0.0129 & В 0.0153 & U 0.0002 & В 0.0054 & 0.0247 & 0.0133 & В 0.00054 & 0.0002 & 21.68 & 8.08 & 128 \\
\hline \multirow{2}{*}{ EC-5-06299-2 } & \multirow{2}{*}{$\begin{array}{c}06 / 29 / 1999 \\
11: 40\end{array}$} & \multirow{2}{*}{$\begin{array}{l}\text { Sample } \\
\text { collected from } \\
\text { sump \#1 }\end{array}$} & Total & 0.0312 & 0.475 & U 0.0002 & 0.040 & 0.0565 & 0.0055 & U 0.0005 & B 0.00062 & N/Anl & N/Anl & N/Anl \\
\hline & & & Dissolved & B 0.0042 & В 0.0295 & B 0.0002 & B 0.0075 & 0.0318 & B 0.0071 & 0.0438 & 0.0002 & 20.34 & 5.96 & 70 \\
\hline \multirow[b]{2}{*}{ EC-5-07099-1 } & \multirow{2}{*}{$\begin{array}{c}\text { 07/09/1999 } \\
08: 30\end{array}$} & \multirow{2}{*}{$\begin{array}{l}\text { Sample } \\
\text { collected from } \\
\text { sump \#1 }\end{array}$} & Total & В 0.0077 & В 0.039 & U 0.0002 & В 0.0032 & B 0.0015 & U 0.0029 & U 0.0007 & U 0.00002 & N/Anl & N/Anl & $\mathrm{N} / \mathrm{Anl}$ \\
\hline & & & Dissolved & B 0.0057 & B 0.0031 & U 0.0002 & B 0.003 & $\begin{array}{c}U \\
0.0013\end{array}$ & U 0.0029 & U 0.0007 & U 0.00002 & 11.50 & 3.66 & -239 \\
\hline \multirow[b]{2}{*}{ EC-5-07099-2 } & \multirow{2}{*}{$\begin{array}{c}\text { 07/09/1999 } \\
08: 45\end{array}$} & \multirow{2}{*}{$\begin{array}{l}\text { Sample } \\
\text { collected from } \\
\text { sump \#2 }\end{array}$} & Total & В 0.007 & B 0.0816 & U 0.0002 & B 0.0015 & B 0.0021 & U 0.0029 & U 0.0007 & U 0.00002 & N/Anl & N/Anl & $\mathrm{N} / \mathrm{Anl}$ \\
\hline & & & Dissolved & B 0.0054 & B 0.0041 & U 0.0002 & $\cup 0.0005$ & $\begin{array}{c}U \\
0.0013\end{array}$ & U 0.0029 & $\cup 0.0007$ & U 0.00002 & 8.11 & 3.56 & 314 \\
\hline \multicolumn{4}{|c|}{ Contract-Required Detection Limit (CRDL) } & 0.01 & 0.1 & 0.005 & 0.01 & 0.003 & 0.005 & 0.01 & 0.0002 & NA & NA & NA \\
\hline \multicolumn{4}{|c|}{ Nevada Drinking Water Standard (NDWS) } & 0.05 & 2.0 & 0.005 & 0.1 & 0.015 & 0.05 & 0.1 & 0.002 & 15 & 50 & 20,000 \\
\hline & & & 5 Times NDWS & 0.25 & 10 & 0.025 & 0.5 & 0.075 & 0.25 & 0.5 & 0.01 & 75 & 250 & 100,000 \\
\hline
\end{tabular}

a Initial analysis for total RCRA metals.

b Analysis of dissolved RCRA metals on a resubmitted sample fraction.

RCRA $=$ Resource Conservation and Recovery Act of 1976

$\mathrm{N} / \mathrm{Anl}=$ not analyzed

$\mathrm{NA}=$ not applicable

$\mathrm{pCi} / \mathrm{L}=$ picocuries per liter

$B=$ result less than the $C R D L$ but greater than the instrument detection limit

$\mathrm{U}=$ result less than the instrument detection limit 
Appendix C

Detailed Lithologic Log for Well ER-EC-5 
Detailed Lithologic Log for ER-EC-5

Logged by Heather Noto and Lance Prothro, Bechtel Nevada

February 7, 2000

\begin{tabular}{|c|c|c|c|c|c|}
\hline $\begin{array}{l}\text { Depth Interval } \\
\text { meters/(feet) }\end{array}$ & $\begin{array}{c}\text { Thickness } \\
\text { meters/ } \\
\text { (feet) }\end{array}$ & $\begin{array}{l}\text { Sample } \\
\text { Type a }^{\text {a }}\end{array}$ & $\begin{array}{l}\text { Laboratory } \\
\text { Analyses }\end{array}$ & Lithologic Description $^{c}$ & $\begin{array}{c}\text { Stratigraphic } \\
\text { Unit }\end{array}$ \\
\hline $\begin{array}{l}0-28.7 \\
(0-94)\end{array}$ & $\begin{array}{l}28.7 \\
(94)\end{array}$ & $\begin{array}{l}\text { DA } \\
\text { No } \\
\text { samples } \\
\text { above } \\
21.3 \mathrm{~m} \\
(70 \mathrm{ft}) \\
\end{array}$ & None & $\begin{array}{l}\text { Partially Welded Ash-Flow Tuff: Grayish-red (10R 4/2); devitrified } \\
\text { with vapor-phase mineralization; minor light-gray (N7) and grayish-red } \\
\text { (10R 4/2) pumice; minor felsic phenocrysts of feldspar, including } \\
\text { chatoyant sanidine; minor mafic minerals of clinopyroxene and } \\
\text { olivine; minor very-dusky-red (10R 2/2) and grayish-brown (5YR 3/2) } \\
\text { lithic fragments. }\end{array}$ & \multirow{3}{*}{$\begin{array}{l}\text { Pahute Mesa } \\
\text { Tuff (Ttp) }\end{array}$} \\
\hline $\begin{array}{c}28.7-32.3 \\
(94-106)\end{array}$ & $\begin{array}{c}3.7 \\
(12)\end{array}$ & DA & None & $\begin{array}{l}\text { Moderately Welded Ash-Flow Tuff: Grayish-brown (5YR 3/2); } \\
\text { devitrified; minor pumice; minor felsic phenocrysts of feldspar, } \\
\text { including chatoyant sanidine; rare mafic minerals of clinopyroxene } \\
\text { and olivine; rare very-dusky-red (10R 2/2) and dusky-reddish-brown } \\
\text { (10R 3/4) lithic fragments. }\end{array}$ & \\
\hline $\begin{array}{l}32.3-37.5 \\
(106-123)\end{array}$ & $\begin{array}{c}5.2 \\
(17)\end{array}$ & DA & None & $\begin{array}{l}\text { Nonwelded Ash-Flow Tuff: Moderate-brown (5YR 4/4); vitric; } \\
\text { abundant light-brown (5YR 5/6) and moderate-brown (5YR 4/4) } \\
\text { pumice; minor felsic phenocrysts of feldspar; minor mafic minerals of } \\
\text { clinopyroxene and olivine; minor lithic fragments. }\end{array}$ & \\
\hline $\begin{array}{l}37.5-64.9 \\
(123-213)\end{array}$ & $\begin{array}{l}27.4 \\
(90)\end{array}$ & $\mathrm{DA}, \mathrm{DB} 1$ & $\begin{array}{c}\text { PTS, XRD, } \\
\text { XRF, } \\
\mathrm{Fe}^{2+} / \mathrm{Fe}^{3+}\end{array}$ & $\begin{array}{l}\text { Nonwelded Ash-Flow Tuff: Moderate yellowish-brown (10YR 5/4), } \\
\text { grayish-brown (5YR 3/2), and moderate-brown (5YR 4/4); devitrified } \\
\text { with vapor-phase mineralization; very abundant light-brown (5YR 5/6) } \\
\text { remnant glass shards; common light-brown (5YR 5/6) pumice; } \\
\text { common felsic phenocrysts of feldspar; minor to common mafic } \\
\text { minerals of clinopyroxene and olivine; minor lithic fragments. } \\
\text { Several samples in this interval are a concentration of loose felsic } \\
\text { crystals. }\end{array}$ & $\begin{array}{l}\text { Rocket Wash } \\
\text { Tuff (Ttr) }\end{array}$ \\
\hline
\end{tabular}




\begin{tabular}{|c|c|c|c|c|c|}
\hline $\begin{array}{c}\text { Depth Interval } \\
\text { meters/(feet) }\end{array}$ & $\begin{array}{c}\text { Thickness } \\
\text { meters/ } \\
\text { (feet) }\end{array}$ & $\begin{array}{l}\text { Sample } \\
\text { Type a }^{\text {a }}\end{array}$ & $\begin{array}{l}\text { Laboratory } \\
\text { Analyses }\end{array}$ & Lithologic Description ${ }^{c}$ & $\underset{\text { Unit }}{\text { Stratigraphic }}$ \\
\hline $\begin{array}{l}64.9-81.7 \\
(213-268)\end{array}$ & $\begin{array}{l}16.8 \\
(55)\end{array}$ & DA & $\begin{array}{c}\text { PTS, XRD, } \\
\text { XRF, } \\
\mathrm{Fe}^{2+} / \mathrm{Fe}^{3+}\end{array}$ & $\begin{array}{l}\text { Reworked Tuff: Moderate-yellowish-brown (10YR 5/4); zeolitic, } \\
\text { some fragments weakly calcareous; common grayish-yellow (5Y 8/4) } \\
\text { to white (N9) pumice; minor frosted felsic phenocrysts of feldspar } \\
\text { and lesser quartz; minor biotite and lesser hornblende; altered } \\
\text { sphene observed; common lithic fragments. }\end{array}$ & \multirow{3}{*}{$\begin{array}{l}\text { Caldera moat } \\
\text { filling } \\
\text { sedimentary } \\
\text { deposits }(\mathrm{TgC}\end{array}$} \\
\hline $\begin{array}{l}81.7-89.0 \\
(268-292)\end{array}$ & $\begin{array}{l}7.3 \\
(24)\end{array}$ & DA & $\begin{array}{c}\text { PTS, XRD, } \\
\text { XRF, } \\
\mathrm{Fe}^{2+} / \mathrm{Fe}^{3+}\end{array}$ & $\begin{array}{l}\text { Nonwelded and Reworked Tuff: Grayish-yellow }(5 Y 8 / 4) \text { and } \\
\text { moderate-yellow (5Y } 7 / 6) \text {; zeolitic and silicic, moderately calcareous; } \\
\text { common grayish-yellow (5Y 8/4) pumice; minor to common felsic } \\
\text { phenocrysts of feldspar and quartz; minor to common biotite, trace } \\
\text { hornblende; common lithic fragments. }\end{array}$ & \\
\hline $\begin{array}{c}89.0-121.3 \\
(292-398)\end{array}$ & $\begin{array}{l}32.3 \\
(106)\end{array}$ & DA & $\begin{array}{c}\text { PTS, XRD, } \\
\text { XRF, } \\
\mathrm{Fe}^{2+} / \mathrm{Fe}^{3+}\end{array}$ & $\begin{array}{l}\text { Reworked Tuff: Moderate-yellowish-brown (10YR 5/4), light-brown } \\
\text { (5YR 5/6), and moderate-reddish-brown (10R 4/6); zeolitic and argillic; } \\
\text { common white (N9) pumice; rare to minor felsic phenocrysts of } \\
\text { feldspar and quartz; minor biotite; minor to common lithic fragments. }\end{array}$ & \\
\hline $\begin{array}{c}121.3-158.5 \\
(398-520)\end{array}$ & $\begin{array}{l}37.2 \\
(122)\end{array}$ & DA & $\begin{array}{c}\text { PTS, XRD, } \\
\text { XRF, } \\
\mathrm{Fe}^{2+} / \mathrm{Fe}^{3+}\end{array}$ & $\begin{array}{l}\text { Nonwelded Tuff: Grayish-orange-pink (5YR 7/2), pale-brown (5YR } \\
5 / 2 \text { ), and light-brown (5YR 6/4); zeolitic, partially silicic with } \\
\text { increasing silicification below approximately } 155.4 \mathrm{~m}(510 \mathrm{ft}) \text {; } \\
\text { common to abundant grayish-orange-pink (5YR 7/2) to pale-greenish- } \\
\text { yellow (10Y 8/2) pumice; common felsic phenocrysts of feldspar; } \\
\text { minor biotite; pseudomorphs after sphene are present; common } \\
\text { brownish-black (5YR 2/1), grayish-brown (5YR 3/2), and moderate- } \\
\text { brown (5YR 3/4) lithic fragments. }\end{array}$ & \multirow{2}{*}{$\begin{array}{l}\text { rhyolite of } \\
\text { Beatty Wash } \\
\text { (Tfbw) }\end{array}$} \\
\hline $\begin{array}{c}158.5-187.5 \\
(520-615)\end{array}$ & $\begin{array}{l}29.0 \\
(95)\end{array}$ & DA & $\begin{array}{c}\text { PTS, XRD, } \\
\text { XRF, } \\
\mathrm{Fe}^{2+} / \mathrm{Fe}^{3+}\end{array}$ & $\begin{array}{l}\text { Nonwelded Tuff: Moderate-reddish-brown (10R 4/6) at top, } \\
\text { becoming very-pale-orange (10YR 8/2), and grayish-orange (10YR } \\
7 / 4 \text { ) lower; zeolitic, weakly silicic; common white (N9) to very-pale- } \\
\text { orange (10YR 8/2) pumice; minor felsic phenocrysts of feldspar; } \\
\text { minor to common biotite; pseudomorphs after sphene are present; } \\
\text { common grayish-brown (5YR 3/2) and brownish-gray (5YR 4/1) lithic } \\
\text { fragments. }\end{array}$ & \\
\hline
\end{tabular}




\begin{tabular}{|c|c|c|c|c|c|}
\hline $\begin{array}{l}\text { Depth Interval } \\
\text { meters/(feet) }\end{array}$ & $\begin{array}{c}\text { Thickness } \\
\text { meters/ } \\
\text { (feet) }\end{array}$ & $\begin{array}{l}\text { Sample } \\
\text { Type a }^{\text {a }}\end{array}$ & $\begin{array}{l}\text { Laboratory } \\
\text { Analyses }\end{array}$ & Lithologic Description $^{c}$ & $\begin{array}{c}\text { Stratigraphic } \\
\text { Unit }\end{array}$ \\
\hline $\begin{array}{c}187.5-246.9 \\
(615-810)\end{array}$ & $\begin{array}{l}59.4 \\
(195)\end{array}$ & DA & $\begin{array}{c}\text { PTS, XRD, } \\
\text { XRF, } \\
\mathrm{Fe}^{2+} / \mathrm{Fe}^{3+}\end{array}$ & $\begin{array}{l}\text { Nonwelded Tuff: Dusky-yellow (5Y 6/4), grayish-orange-pink (5YR } \\
7 / 2) \text {, and grayish-orange (10YR } 7 / 4) \text {; zeolitic and silicic, with } \\
\text { silicification increasing below } 240.8 \mathrm{~m}(790 \mathrm{ft}) \text {; common pumice; } \\
\text { common felsic phenocrysts of feldspar; minor to common biotite; } \\
\text { pseudomorphs after sphene are present; common lithic fragments, } \\
\text { possibly becoming more lithic-rich below } 240.8 \mathrm{~m} \text { ( } 790 \mathrm{ft}) \text {. }\end{array}$ & Tfbw \\
\hline $\begin{array}{c}246.9-253.6 \\
(810-832)\end{array}$ & $\begin{array}{l}6.7 \\
(22)\end{array}$ & DA & $\begin{array}{c}\text { PTS, XRD, } \\
\text { XRF, } \\
\mathrm{Fe}^{2+} / \mathrm{Fe}^{3+}\end{array}$ & $\begin{array}{l}\text { Landslide Breccia: Angular clasts of moderate-brown (5YR 3/4), } \\
\text { quartzo-feldspathic, densely welded ash-flow tuff resembling mafic- } \\
\text { poor Ammonia Tanks Tuff in a scarce, coarse-grained, granular, } \\
\text { tuffaceous matrix. }\end{array}$ & \multirow{4}{*}{$\begin{array}{l}\text { Timber } \\
\text { Mountain } \\
\text { landslide } \\
\text { breccia } \\
(\text { Tmx })^{d}\end{array}$} \\
\hline $\begin{array}{c}253.6-263.3 \\
(832-864)\end{array}$ & $\begin{array}{c}9.8 \\
(32)\end{array}$ & DA, DB1 & None & $\begin{array}{l}\text { Tuffaceous Gravel: Very abundant, subangular to subrounded } \\
\text { clasts of grayish-brown (5YR } 3 / 2) \text {, quartzo-feldspathic, moderately } \\
\text { welded ash-flow tuff resembling mafic-poor Ammonia Tanks Tuff in a } \\
\text { scarce, very-pale-orange (10YR 8/2), fine-grained, zeolitic matrix. }\end{array}$ & \\
\hline $\begin{array}{c}263.3-268.2 \\
(864-880)\end{array}$ & $\begin{array}{c}4.9 \\
(16)\end{array}$ & DA & None & $\begin{array}{l}\text { Landslide Breccia: Very similar to interval } 246.9-253.6 \mathrm{~m} \text { ( } 810 \text { - } \\
832 \mathrm{ft}) \text { with angular clasts of moderate-brown (5YR 3/4), quartzo- } \\
\text { feldspathic, densely welded ash-flow tuff resembling mafic-poor } \\
\text { Ammonia Tanks Tuff in a scarce, coarse-grained, granular, } \\
\text { tuffaceous matrix. }\end{array}$ & \\
\hline $\begin{array}{c}268.2-277.4 \\
(880-910)\end{array}$ & $\begin{array}{l}9.1 \\
(30)\end{array}$ & DA & $\begin{array}{c}\text { PTS, XRD, } \\
\text { XRF, } \\
\mathrm{Fe}^{2+} / \mathrm{Fe}^{3+}\end{array}$ & $\begin{array}{l}\text { Bedded Tuff: Samples consist of various tuffaceous lithologies } \\
\text { primarily nonwelded and reworked tuff. The nonwelded tuff is } \\
\text { moderate-reddish-orange (10R } 6 / 6) \text {, zeolitic, with common pale- } \\
\text { greenish-yellow ( } 10 \mathrm{Y} 8 / 2) \text { pumice, minor felsic phenocrysts of quartz } \\
\text { and feldspar, minor biotite, and minor lithic fragments. The reworked } \\
\text { tuff is mostly pale-brown (5YR } 5 / 2) \text {, and lesser moderate-brown ( } 5 \mathrm{YR} \\
4 / 4 \text { ) and moderate-reddish-brown (10R } 4 / 6) \text {, consisting of mostly fine } \\
\text { to medium sand, with lesser coarse to very coarse sand in a very- } \\
\text { fine-grained, zeolitic, tuffaceous matrix; grains are moderately sorted } \\
\text { and subangular and consist of frosted quartz and feldspar crystals, } \\
\text { biotite, pumice, and various volcanic fragments. }\end{array}$ & \\
\hline
\end{tabular}




\begin{tabular}{|c|c|c|c|c|c|}
\hline $\begin{array}{c}\text { Depth Interval } \\
\text { meters/(feet) }\end{array}$ & $\begin{array}{c}\text { Thickness } \\
\text { meters/ } \\
\text { (feet) }\end{array}$ & $\begin{array}{l}\text { Sample } \\
\text { Type }^{a}\end{array}$ & $\begin{array}{l}\text { Laboratory } \\
\text { Analyses }\end{array}$ & Lithologic Description $^{c}$ & $\begin{array}{c}\text { Stratigraphic } \\
\text { Unit }\end{array}$ \\
\hline $\begin{array}{l}277.4-305.4 \\
(910-1,002)\end{array}$ & $\begin{array}{l}28.0 \\
(92)\end{array}$ & DA & $\begin{array}{c}\text { PTS, XRD, } \\
\text { XRF, } \\
\mathrm{Fe}^{2+} / \mathrm{Fe}^{3+}\end{array}$ & $\begin{array}{l}\text { Landslide Breccia: Similar to intervals } 246.9-253.6 \mathrm{~m} \text { ( } 810 \text { - } \\
832 \mathrm{ft} \text { ) and } 263.3-268.2 \mathrm{~m} \text { ( } 864-880 \mathrm{ft} \text { ) with angular clasts of } \\
\text { moderate-brown (5YR 3/4), quartzo-feldspathic, densely welded ash- } \\
\text { flow tuff resembling mafic-poor Ammonia Tanks Tuff in a scarce, } \\
\text { coarse-grained, granular, tuffaceous matrix. }\end{array}$ & \multirow[b]{2}{*}{$\operatorname{Tmx}$} \\
\hline $\begin{array}{c}305.4-321.9 \\
(1,002-1,056)\end{array}$ & $\begin{array}{l}16.5 \\
(54)\end{array}$ & $\mathrm{DA}, \mathrm{DB} 1$ & $\begin{array}{c}\text { PTS, XRD, } \\
\text { XRF, } \\
\mathrm{Fe}^{2+} / \mathrm{Fe}^{3+}\end{array}$ & $\begin{array}{l}\text { Reworked Tuff: Light-brown (5YR 6/4), pale-brown (5YR 5/2), and } \\
\text { moderate-reddish-orange (10R 6/6); zeolitic and lesser argillic, } \\
\text { moderately calcareous; common felsic phenocrysts of frosted } \\
\text { feldspar and quartz; common to abundant biotite and trace sphene; } \\
\text { very abundant grayish-brown (5YR 3/2), brownish-black (5YR } 2 / 1) \text {, } \\
\text { and dark-gray (N3) subangular to subrounded lithic fragments of } \\
\text { densely welded tuff resembling mafic-poor Ammonia Tanks Tuff. }\end{array}$ & \\
\hline $\begin{array}{c}321.9-335.0 \\
(1,056-1,099)\end{array}$ & $\begin{array}{l}13.1 \\
(43)\end{array}$ & $\mathrm{DA}$ & None & $\begin{array}{l}\text { Densely Welded to Vitrophyric Ash-Flow Tuff: Mostly moderate- } \\
\text { brown (5YR 4/4), lesser light-brown (5YR 5/6) and grayish-black (N2); } \\
\text { mostly devitrified, lesser vitric, weakly calcareous; remnant perlitic } \\
\text { texture in some cuttings fragments; minor pumice; abundant felsic } \\
\text { phenocrysts of feldspar and lesser quartz; very abundant biotite and } \\
\text { lesser clinopyroxene; minor dark-reddish-brown (10R } 3 / 4 \text { ) lithic } \\
\text { fragments. } \\
\text { Induction log indicates vitrophyre from } 328.0 \text { to } 333.1 \mathrm{~m} \text { ( } 1,076 \text { to } \\
1,093 \mathrm{ft}) \text {. }\end{array}$ & \multirow{2}{*}{$\begin{array}{c}\text { mafic-rich } \\
\text { Ammonia } \\
\text { Tanks Tuff } \\
\text { (Tmar) }\end{array}$} \\
\hline $\begin{array}{c}335.0-434.0 \\
(1,099-1,424)\end{array}$ & $\begin{array}{l}99.1 \\
(325)\end{array}$ & $\mathrm{DA}, \mathrm{SC}$ & $\begin{array}{c}\text { PTS, XRD, } \\
\text { XRF, } \\
\mathrm{Fe}^{2+} / \mathrm{Fe}^{3+}\end{array}$ & $\begin{array}{l}\text { Moderately Welded Ash-Flow Tuff: Pale-brown (5YR } 5 / 2) \text { and } \\
\text { moderate-brown ( } 5 \text { YR } 4 / 4) \text {; quartzo-feldspathic, minor zeolitic and/or } \\
\text { argillic alteration from } 408.4 \text { to } 429.8 \mathrm{~m}(1,340 \text { to } 1,410 \mathrm{ft}) \text {; rare to } \\
\text { minor pumice; abundant felsic phenocrysts of partially altered } \\
\text { feldspar and lesser quartz; very abundant unaltered biotite; common } \\
\text { lithic fragments. } \\
\text { Calcite occurs as coatings on fragments and as vein fillings. }\end{array}$ & \\
\hline
\end{tabular}




\begin{tabular}{|c|c|c|c|c|c|}
\hline $\begin{array}{l}\text { Depth Interval } \\
\text { meters/(feet) }\end{array}$ & $\begin{array}{c}\text { Thickness } \\
\text { meters/ } \\
\text { (feet) }\end{array}$ & $\begin{array}{l}\text { Sample } \\
\text { Type a }^{\text {a }}\end{array}$ & $\begin{array}{l}\text { Laboratory } \\
\text { Analyses }\end{array}$ & Lithologic Description ${ }^{c}$ & $\begin{array}{c}\text { Stratigraphic } \\
\text { Unit }\end{array}$ \\
\hline $\begin{array}{c}434.0-462.1 \\
(1,424-1,516)\end{array}$ & $\begin{array}{l}28.0 \\
(92)\end{array}$ & $\mathrm{DA}, \mathrm{SC}$ & None & $\begin{array}{l}\text { Moderately Welded Ash-Flow Tuff: Moderate-brown ( } 5 \text { YR } 3 / 4) \text {, } \\
\text { moderate-brown ( } 5 \text { YR 4/4), and grayish-red (5R 4/2); quartzo- } \\
\text { feldspathic, minor argillic and/or zeolitic alteration, and moderately } \\
\text { calcareous; minor pumice; abundant felsic phenocrysts of quartz and } \\
\text { feldspar, including partially altered feldspar and pseudomorphs after } \\
\text { feldspar; abundant unaltered biotite; minor lithic fragments. }\end{array}$ & \multirow{3}{*}{ Tmar } \\
\hline $\begin{array}{c}462.1-513.0 \\
(1,516-1,683)\end{array}$ & $\begin{array}{l}50.9 \\
(167)\end{array}$ & $\mathrm{DA}, \mathrm{SC}$ & $\begin{array}{l}\text { PTS, XRD, } \\
\text { XRF, } \\
\mathrm{Fe}^{2+} / \mathrm{Fe}^{3+}\end{array}$ & $\begin{array}{l}\text { Moderately Welded Ash-Flow Tuff: Moderate-brown (5YR 4/4) and } \\
\text { moderate-brown (5YR } 3 / 4) \text {; quartzo-feldspathic with minor zeolitic } \\
\text { and/or argillic alteration; common felsic phenocrysts of quartz and } \\
\text { feldspar, including chatoyant sanidine and partially altered feldspar } \\
\text { and pseudomorphs after feldspar; abundant unaltered biotite; minor } \\
\text { lithic fragments. }\end{array}$ & \\
\hline $\begin{array}{c}513.0-678.2 \\
(1,683-2,225)\end{array}$ & $\begin{array}{l}165.2 \\
(542)\end{array}$ & $\mathrm{DA}, \mathrm{SC}$ & $\begin{array}{l}\text { PTS, XRD, } \\
\text { XRF, } \\
\mathrm{Fe}^{2+} / \mathrm{Fe}^{3+}\end{array}$ & $\begin{array}{l}\text { Moderately Welded Ash-Flow Tuff: Moderate-brown (5YR 3/4), } \\
\text { grayish-brown (5YR 3/2), dark-reddish-brown (10R 3/4), and } \\
\text { moderate-brown (5YR 4/4); quartzo-feldspathic alteration with } \\
\text { substantial silicification, weakly to moderately calcareous; abundant } \\
\text { felsic phenocrysts of feldspar, including partially altered feldspar and } \\
\text { pseudomorphs after feldspar, and lesser quartz; abundant unaltered } \\
\text { biotite. }\end{array}$ & \\
\hline $\begin{array}{c}678.2-680.6 \\
(2,225-2,233)\end{array}$ & $\begin{array}{l}2.4 \\
(8)\end{array}$ & DA & None & $\begin{array}{l}\text { Moderately Welded Ash-Flow Tuff: Moderate-reddish-brown (10R } \\
\text { 4/6), light-brown ( } 5 \text { YR } 5 / 6) \text {, and moderate-brown (5YR 4/4); quartzo- } \\
\text { feldspathic with substantial silicification; common to abundant felsic } \\
\text { phenocrysts of feldspar, including partially altered feldspar and } \\
\text { pseudomorphs after feldspar, and lesser quartz; minor to common } \\
\text { unaltered biotite. }\end{array}$ & \multirow{2}{*}{$\begin{array}{c}\text { mafic-poor } \\
\text { Ammonia } \\
\text { Tanks Tuff } \\
\text { (Tmap) }\end{array}$} \\
\hline $\begin{array}{c}680.6-682.8 \\
(2,233-2,240)\end{array}$ & $\begin{array}{l}2.1 \\
(7)\end{array}$ & DA & None & $\begin{array}{l}\text { Vitrophyric Ash-Flow Tuff: Grayish-black (N2) and brownish-black } \\
\text { (5YR 2/1); mostly vitric, lesser devitrified and silicic; common felsic } \\
\text { phenocrysts of feldspar and quartz; minor biotite. }\end{array}$ & \\
\hline
\end{tabular}




\begin{tabular}{|c|c|c|c|c|c|}
\hline $\begin{array}{c}\text { Depth Interval } \\
\text { meters/(feet) }\end{array}$ & $\begin{array}{c}\text { Thickness } \\
\text { meters/ } \\
\text { (feet) }\end{array}$ & $\begin{array}{l}\text { Sample } \\
\text { Type a }^{\text {a }}\end{array}$ & $\begin{array}{l}\text { Laboratory } \\
\text { Analyses }\end{array}$ & Lithologic Description ${ }^{c}$ & $\begin{array}{c}\text { Stratigraphic } \\
\text { Unit }\end{array}$ \\
\hline $\begin{array}{c}682.8-744.9 \\
(2,240-2,444)\end{array}$ & $\begin{array}{l}62.2 \\
(204)\end{array}$ & $\mathrm{DA}, \mathrm{SC}$ & $\begin{array}{c}\text { PTS, XRD, } \\
\text { XRF, } \\
\mathrm{Fe}^{2+} / \mathrm{Fe}^{3+}\end{array}$ & $\begin{array}{l}\text { Moderately to Densely Welded Ash-Flow Tuff: Pale-brown (5YR } \\
5 / 2 \text { ), moderate-brown ( } 5 \text { YR } 3 / 4 \text { ), and light-brown (5YR 5/6); quartzo- } \\
\text { feldspathic alteration, with substantial silicification in some intervals; } \\
\text { common felsic phenocrysts of quartz and feldspar, including partially } \\
\text { altered feldspar; minor unaltered biotite; minor lithic fragments. }\end{array}$ & Tmap \\
\hline
\end{tabular}

a $\quad$ DA $=$ drill cuttings that represent lithologic character of interval; $\mathbf{D B 1}=$ drill cuttings enriched in hard components; $\mathbf{S C}=$ sidewall core.

b $\quad$ PTS $=$ polished thin section $\mathbf{X R D}=\mathbf{X}$-ray diffraction; $\mathbf{X R F}=\mathbf{X}$-ray fluorescence; $\mathbf{F e}^{2+} / \mathbf{F e}^{3+}=$ wet chemical analysis for iron. See Table 3-2 of this report for additional information.

c Descriptions are based on visual examination of lithologic samples using a 10x-to 40x-zoom binocular microscope and incorporating observations from geophysical logs. Colors describe wet sample color. Abundances for felsic phenocrysts, pumice fragments, and lithic fragments:

trace $=$ only one or two individuals observed; rare $=\leq 1 \%$; minor $=5 \%$; common $=10 \%$; abundant $=15 \%$; very abundant $=\geq 20 \%$.

Abundances for mafic minerals: trace $=$ only one or two individuals observed; rare $=\leq 0.05 \%$; minor $=0.2 \%$; common $=0.5 \%$; abundant $=1 \%$; very abundant $=\geq 2 \%$

d See discussion in Section 4-1 of this report for origin of rocks assigned as Tmx in Well ER-EC-5. 


\section{Appendix D}

Well ER-EC-5 Geophysical Logs 
Appendix D contains unprocessed data presentations of selected geophysical logs run in Well ER-EC-5. Table D-1 summarizes the header information for logs presented. See Table 3-3 for information about other logs run in Well ER-EC-5.

\section{Table D-1}

Well ER-EC-5 Geophysical Logs Presented

\begin{tabular}{|c|c|c|c|c|}
\hline Log Type & $\begin{array}{l}\text { Run } \\
\text { Number }\end{array}$ & Date & \multicolumn{2}{|c|}{ meters ${ }^{\text {Log Interval }}$ feet } \\
\hline Epithermal Neutron & $\begin{array}{l}\text { ENP-1 } \\
\text { ENP-2 }\end{array}$ & $\begin{array}{l}06 / 28 / 1999 \\
07 / 05 / 1999\end{array}$ & $\begin{array}{c}21.3-338.3 \\
173.1-761.4\end{array}$ & $\begin{array}{r}70-1,110 \\
568-2,498\end{array}$ \\
\hline Density & $\begin{array}{l}\text { CDL-1 } \\
\text { CDL-2 }\end{array}$ & $\begin{array}{l}06 / 28 / 1999 \\
07 / 05 / 1999\end{array}$ & $\begin{array}{c}21.3-338.3 \\
173.1-761.4\end{array}$ & $\begin{array}{c}70-1,110 \\
568-2,498\end{array}$ \\
\hline $\begin{array}{l}\text { Array Induction and Dual Laterolog } \\
\text { (resistivity) }\end{array}$ & $\begin{array}{l}\text { IND-1 } \\
\text { DLL-1 }\end{array}$ & $\begin{array}{l}06 / 28 / 1999 \\
07 / 05 / 1999\end{array}$ & $\begin{array}{l}\text { 21.3. }-340.2 \\
342.6-757.4\end{array}$ & $\begin{array}{c}70-1,116 \\
1,124-2,485\end{array}$ \\
\hline Gamma Ray & $\begin{array}{l}\text { SGR-1 } \\
\text { GR-2 }\end{array}$ & $\begin{array}{l}06 / 28 / 1999 \\
07 / 05 / 1999\end{array}$ & $\begin{array}{r}21.3-329.8 \\
342.6-761.7\end{array}$ & $\begin{array}{c}70-1,082 \\
1,124-2,499\end{array}$ \\
\hline $\begin{array}{l}\text { Digital Array Sonic } \\
\text { (delta T and sonic porosity) }\end{array}$ & $A C-1$ & 07/07/1999 & $304.8-753.8$ & $1,000-2,473$ \\
\hline $\begin{array}{c}\text { Spectral Gamma Ray } \\
\text { (potassium, thorium, uranium) }\end{array}$ & $\begin{array}{l}\text { SGR-1 } \\
\text { SGR-2 }\end{array}$ & $\begin{array}{l}06 / 28 / 1999 \\
07 / 06 / 1999\end{array}$ & $\begin{array}{r}21.3-329.8 \\
310.9-752.6\end{array}$ & $\begin{array}{c}70-1,082 \\
1,020-2,469\end{array}$ \\
\hline Thermal Flow & 1 & 07/07/1999 & $310.6-755.9$ & $1,019-2,480^{a}$ \\
\hline $\begin{array}{c}\text { Chemistry } \\
\text { (temperature, } \mathrm{pH}, \text { electrical conductivity) }\end{array}$ & 1 & 07/07/1999 & $310.6-755.9$ & $1,019-2,480$ \\
\hline
\end{tabular}

a Logging interval recorded on print of log. Discrete measurements were made at seven locations between the depths of 387.1 and $749.2 \mathrm{~m}(1,270$ and 2,458 ft). 


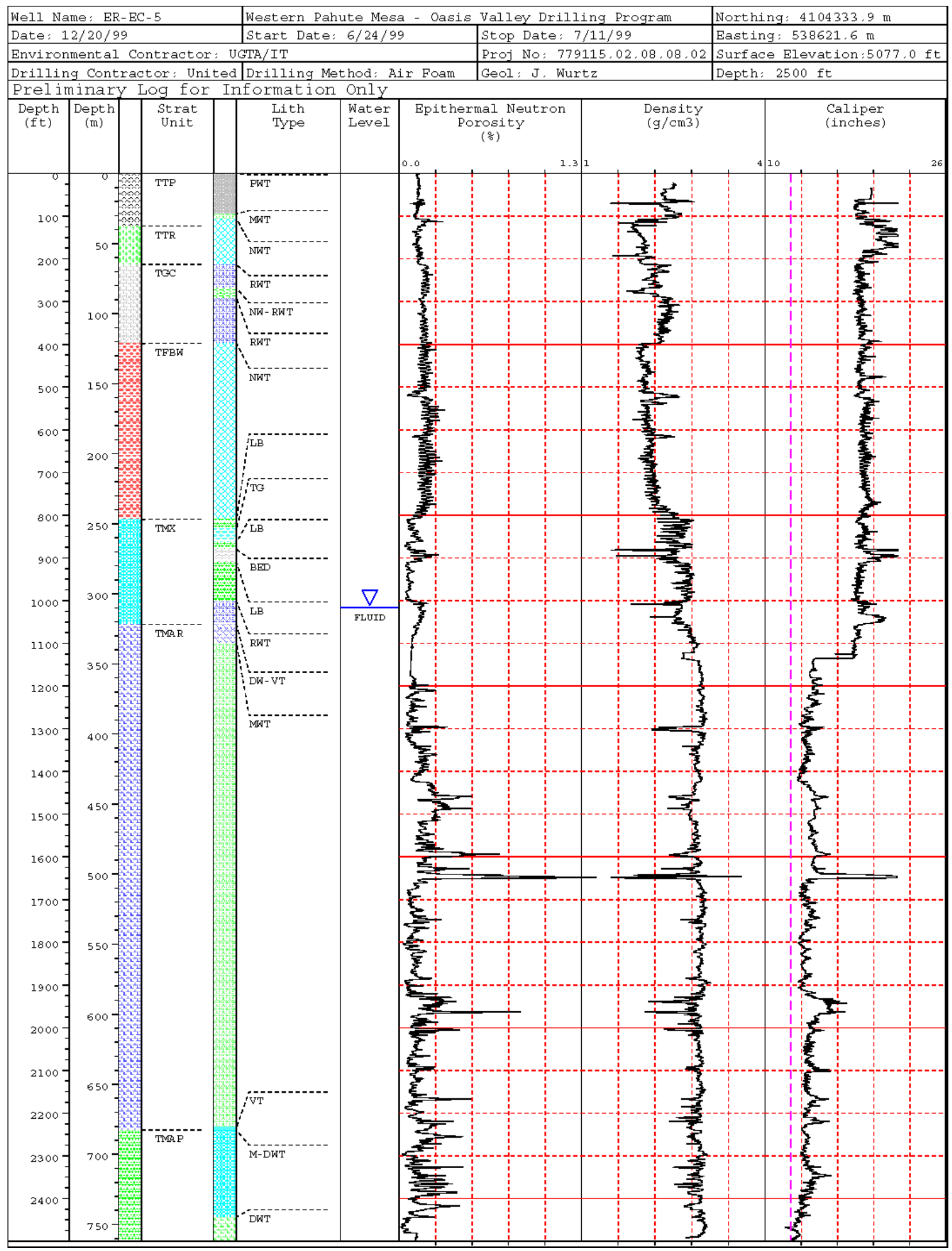




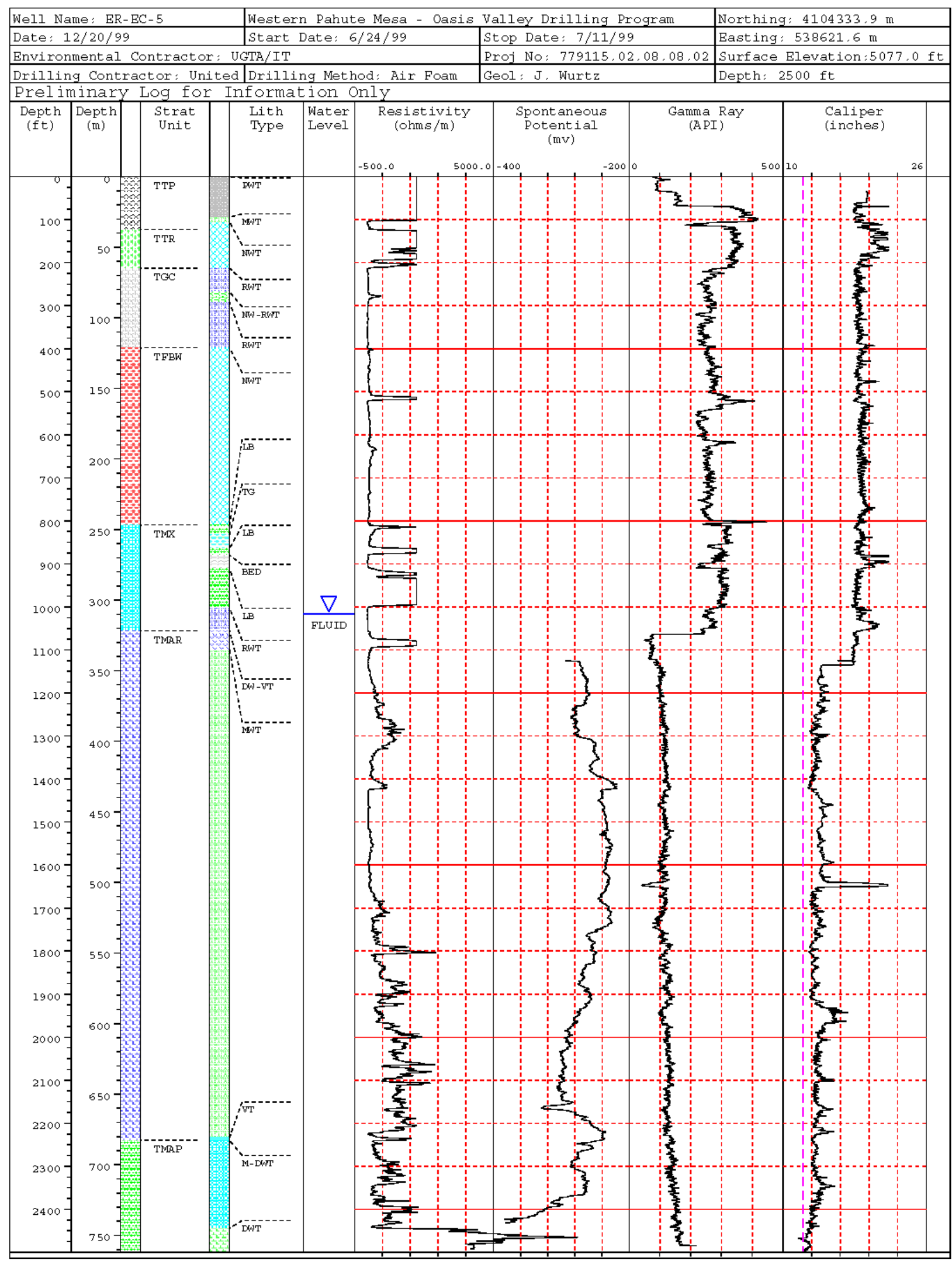




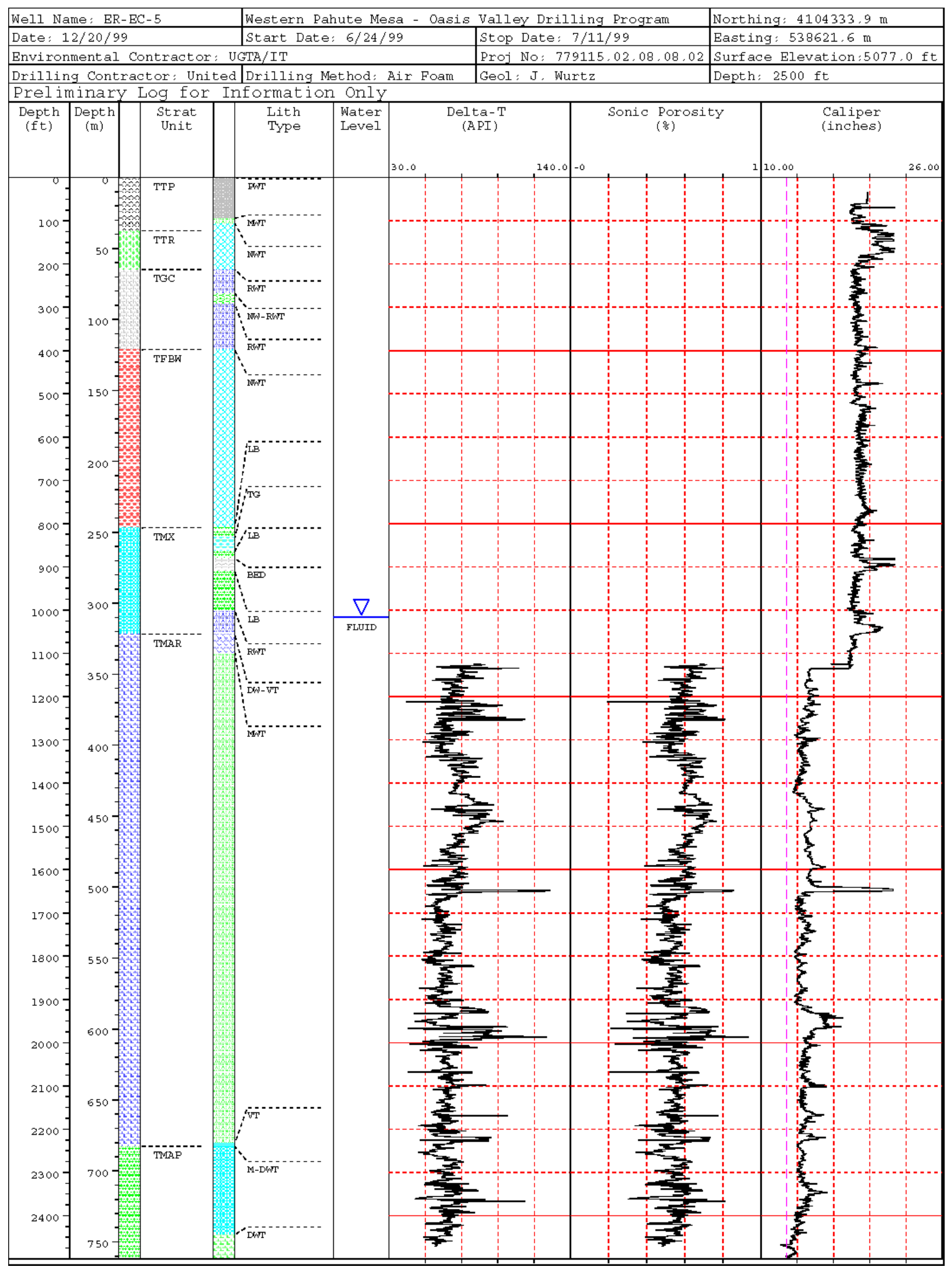




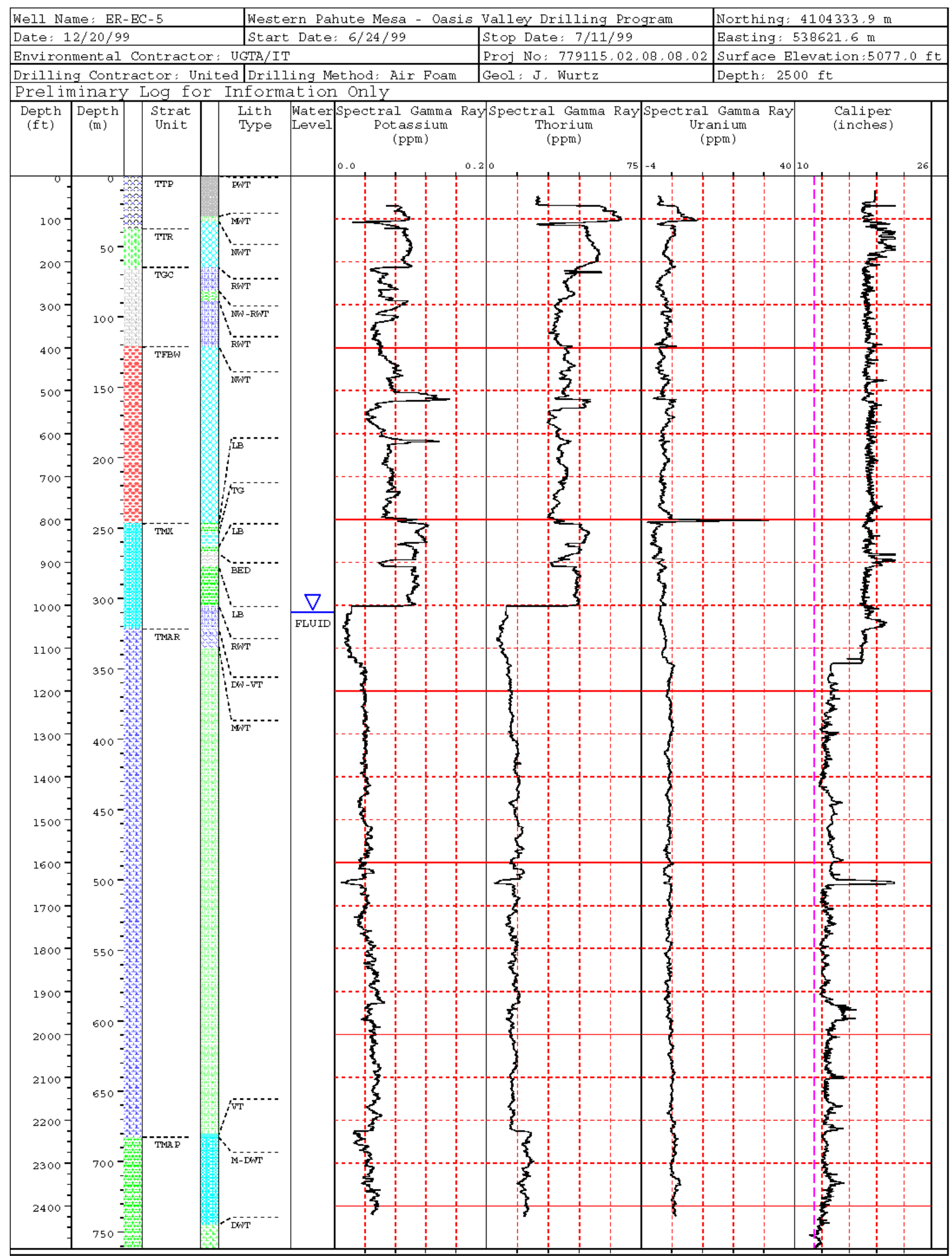




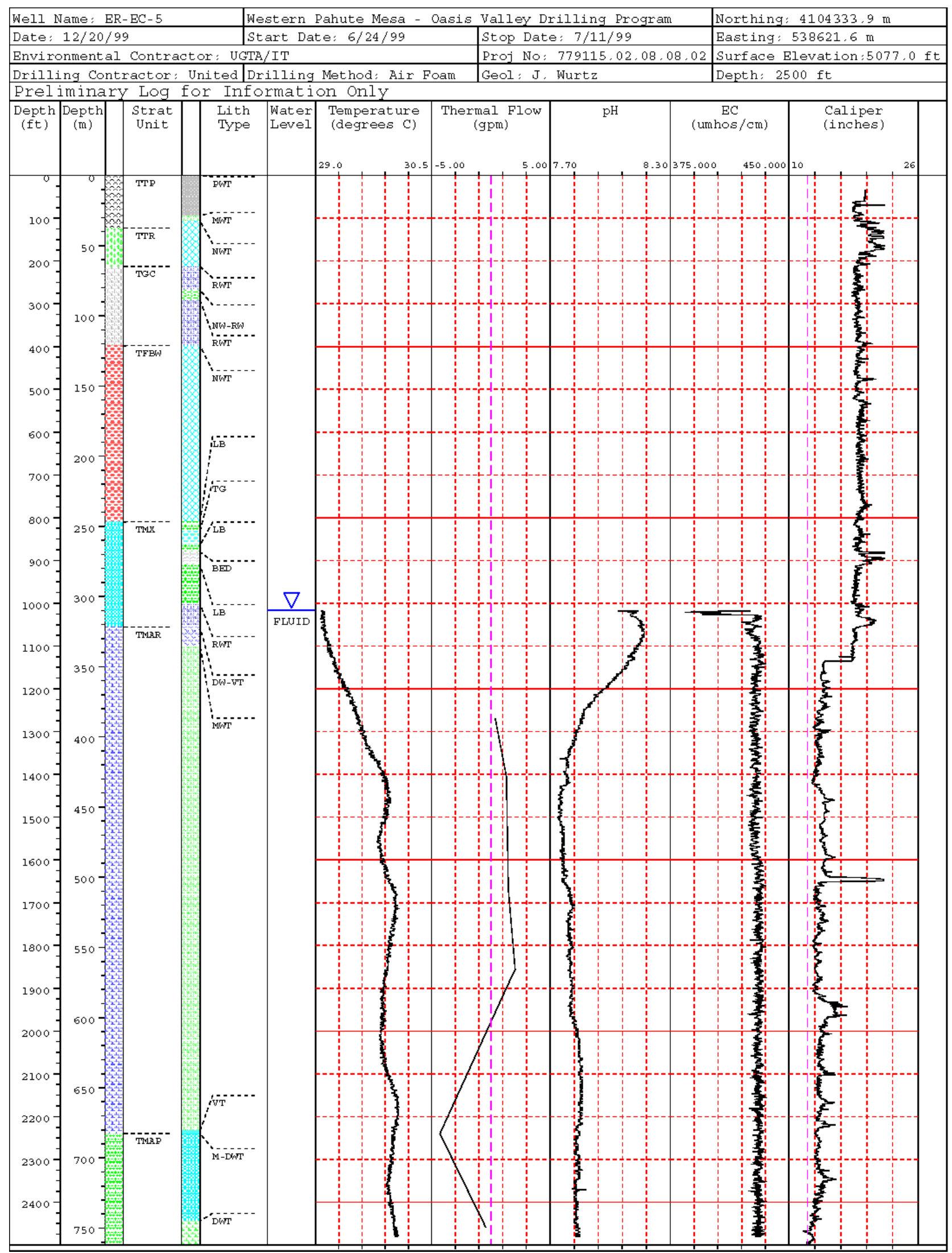




\section{Distribution List}

$\underline{\text { Copies }}$

R. M. Bangerter

2

U.S. Department of Energy

National Nuclear Security Administration

Nevada Site Office

Environmental Restoration Division

P.O. Box 98518, M/S 505

Las Vegas, NV 89193-8518

U.S. Department of Energy

National Nuclear Security Administration

Nevada Site Office

Technical Library

P.O. Box 98518, M/S 505

Las Vegas, NV 89193-8518

U.S. Department of Energy

National Nuclear Security Administration

Nevada Site Office

Public Reading Facility

C/O Nuclear Testing Archive

P.O. Box 98518, M/S 505

Las Vegas, NV 89193-8518

U.S. Department of Energy

1 (electronic)

Office of Scientific and Technical Information

Post Office Box 62

Oak Ridge, Tennessee 37831-0062

K. A. Hoar, Director

U.S. Department of Energy

National Nuclear Security Administration

Nevada Site Office

Environment, Safety and Health Division

P.O. Box 98518, M/S 505

Las Vegas, NV 89193-8518

P. K. Ortego

Bechtel Nevada

P.O. Box 98521, MS NLV082

Las Vegas, NV 89193-8521 


\section{Distribution List (continued)}

\section{$\underline{\text { Copies }}$}

John McCord

UGTA Project Manager

Stoller-Navarro

7710 West Cheyenne Ave.

Building 3

Las Vegas, NV 89129

Stoller-Navarro Library

Stoller-Navarro

7710 West Cheyenne Ave.

Building 3

Las Vegas, NV 89129

W. L. Hawkins

Los Alamos National Laboratory

P. O. Box 1663

Los Alamos, NM 87545-1663

G. A. Pawloski

Lawrence Livermore National Laboratory

P. O. Box 808

Livermore, CA 94551-0808

T. P. Rose

Lawrence Livermore National Laboratory

P. O. Box 808

Livermore, CA 94551-0808

B. K. Thompson

DOE/USGS Cooperative Program Manager

U.S. Geological Survey

Water Resources Division

6770 South Paradise Road

Las Vegas, NV 89119-3721

C. E. Russell

Desert Research Institute

755 East Flamingo Road

P.O. Box 19040

Las Vegas, NV 89119-7363 